Rhode Island College

Digital Commons @ RIC

$12-1-2019$

\title{
The Impact of Parental Presence on the Anxiety Experienced by Pediatric Patients During Anesthesia
}

\author{
Cassie McEnery
}

Follow this and additional works at: https://digitalcommons.ric.edu/etd

Part of the Nursing Commons

\section{Recommended Citation}

McEnery, Cassie, "The Impact of Parental Presence on the Anxiety Experienced by Pediatric Patients During Anesthesia" (2019). Master's Theses, Dissertations, Graduate Research and Major Papers Overview. 317.

https://digitalcommons.ric.edu/etd/317

This Major Paper is brought to you for free and open access by the Master's Theses, Dissertations, Graduate Research and Major Papers at Digital Commons @ RIC. It has been accepted for inclusion in Master's Theses, Dissertations, Graduate Research and Major Papers Overview by an authorized administrator of Digital Commons @ RIC. For more information, please contact digitalcommons@ric.edu. 



\section{THE IMPACT OF PARENTAL PRESENCE ON THE ANXIETY EXPERIENCED BY PEDIATRIC PATIENTS DURING ANESTHESIA}

A Major Paper Presented

by

Cassie McEnery

Approved:

Committee Chairperson

Committee Members

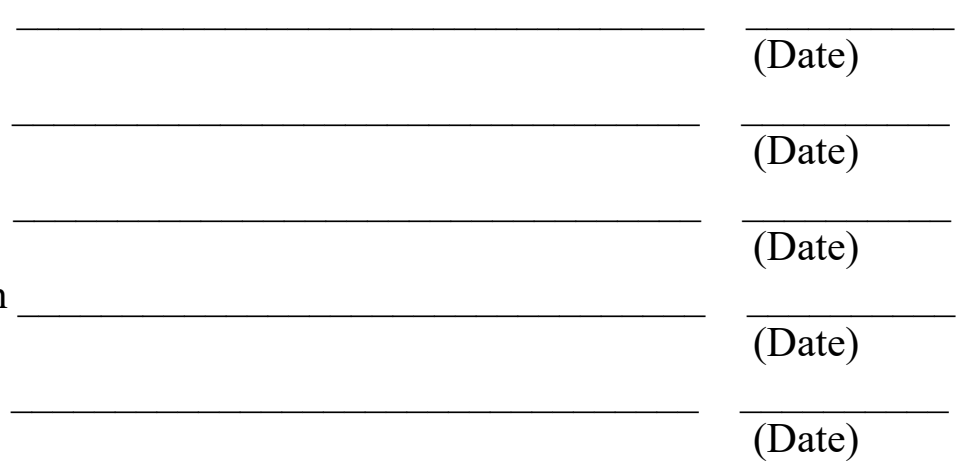




\title{
THE IMPACT OF PARENTAL PRESENCE ON THE ANXIETY EXPERIENCED BY PEDIATRIC PATIENTS DURING ANESTHESIA
}

\author{
by
}

Cassie McEnery

A Major Paper Submitted in Partial Fulfillment

of the Requirements for the Degree of

Master of Science in Nursing

in

The School of Nursing

Rhode Island College

2019 


\begin{abstract}
This integrative review compared the use and impact of parental presence on the anxiety experienced by pediatric patients during anesthesia. Every year, millions of children receive anesthesia and experience separation from their parents which can cause anxiety due to unfamiliar situations, environments, or people. A search was completed using electronic databases, including Cumulative Index to Nursing and Allied Health Literature (CINAHL) and Pubmed. The PRISMA flowchart was utilized, guided by inclusion and exclusion criteria, to identify and document the six studies included in the review. Studies were critically appraised using Polit \& Beck's critical analysis tables to evaluate the quality of the studies included in the review. The primary outcome examined was anxiety. A cross study analysis was performed to examine the reviewed literature for common themes. Findings showed mixed results in the overall anxiety levels when pediatric patients were accompanied to the operating room with a parent. Parental presence is a strategy that can be used to reduce anxiety and improve satisfaction in pediatric patients requiring anesthesia. More research is recommended. Overall, this integrative review supported parental presence and distraction techniques to reduce anxiety during anesthesia in pediatric patients.
\end{abstract}




\section{Acknowledgements}

To my wonderful husband for the endless support, love and encouragement. You are the reason I was able to accomplish my goals and dreams. Logan and Brayden always believe in yourself and go for what makes you happy. I love you with all my heart! 


\section{Table of Contents}

Background/Statement of the Problem 1

Literature Review 4

Theoretical Framework $\quad 23$

$\begin{array}{ll}\text { Method } & 26\end{array}$

$\begin{array}{ll}\text { Results } & 30\end{array}$

Summary and Conclusions $\quad 42$

Recommendations and Implications for Advanced Nursing Practice 45

$\begin{array}{ll}\text { References } & 47\end{array}$

$\begin{array}{ll}\text { Appendices } & 55\end{array}$ 
The Impact of Parental Presence on the Anxiety Experienced by Pediatric Patients During Anesthesia

\section{Background/Statement of the Problem}

Children of all ages may experience anxiety before a surgical procedure. Infants commonly experience stranger anxiety as early as six months of age whereas toddlers and preschool age children experience separation anxiety, fear 'the unknown', and may perceive surgery as a punishment (Scully, 2012). Reduction in anxiety should be an important consideration from the time of surgical planning throughout the pre- and postoperative continuum and a plan for perioperative anxiety management should be prioritized.

When children are faced with unfamiliar situations, environments, or people, they are more susceptible to feelings of unease. The hospital setting is a particularly anxietyproducing environment for children and preoperative anxiety is a common reaction experienced by children who are about to undergo invasive procedures (Fortier, Del Rosario, Martin, \& Kain, 2010; Watson \& Visram, 2003; Wright, Stewart, Finley, \& Buffett-Jerrott, 2007). Fortier, Martin, Chorney, Mayers, \& Kain, 2011 found that children demonstrate noticeable anxiety between the holding area and being separated from their parents as they go to the operating room. Anxiety is not only concerning in the preoperative phase, but also can be detrimental postoperatively. For example, Banchs and Lerman (2014) noted increased preoperative anxiety and the incidence of emergence delirium and new-onset postoperative negative behaviors. These researchers found that anxiety prior to surgery can lead to negative behaviors such as separation anxiety, hostility, delayed emergence, and nightmares. This can be a challenge for healthcare 
professionals who are caring for these children as well as an emotional struggle for the children and their parents.

The induction phase of anesthesia has been found to be the most distressing and anxiety-provoking aspect of the perioperative period in children (Fortier et al., 2011; Kain, Mayes, Caldwell-Andrews, Karas, \& McClain, 2006). It is therefore essential that preoperative planning includes tools and interventions directed at reducing parental and child anxiety and distress during induction of anesthesia. Pharmaceuticals, parental presence, and distraction are common approaches used when treating preoperative anxiety in children. Pharmacological medications such as midazolam, are commonly used as sedative pre-medications in the preoperative holding area. Sedative medications have been shown to be effective in reducing preoperative anxiety in children (Kumari, Agrawal, Usha, Talwar, \& Gupta, 2017; Vagnoli, Caprilli, \& Messeri, 2010), but they have many undesirable side effects and can cause delayed emergence from anesthesia. As an alternative, non-pharmacological distraction methods have been used as a method to reduce anxiety in children and their families. Parental presence during induction of anesthesia (PPIA) is one non-pharmacological intervention that is aimed at reducing anxiety in children prior to surgery. Many parents choose to be present during induction of anesthesia in hopes of diminishing the child's anxiety and easing the induction process for the child and anesthesia provider.

Numerous benefits have been put forth for having parents present at anesthesia induction (McCann \& Kain, 2001); however, the current literature has demonstrated a surprising lack of interest. Published controlled trials of PPIA are few and dated (Bevan et al., 1990; Kain, Mayes, O’Connor, \& Cicchetti, 1996; Schulman, Foley, Vernon, \& 


\begin{abstract}
Allan, 1967). Most of the studies have compared parental presence to behavioral or pharmacological interventions. The purpose of this paper is to explore the impact of PPIA on pediatric patients' anxiety during the operative experience. An integrative review will be conducted to investigate this problem further and incorporate the available research. Evidence is needed to determine varying effects of parental presence to identify modifiable variables that contribute to this PPIA reducing anxiety levels in pediatric patient undergoing surgical procedures.
\end{abstract}

Next, the review of literature will be presented. 


\section{Literature Review}

\section{Anxiety}

Anxiety is a universal and normative emotional reaction. Although potentially problematic, anxiety is an adaptive response, which prepares the mind and body to react in dangerous situations. This fight-or-flight response controls the sympathetic nervous system and responds to anxiety that signals the brain to send a rush of adrenaline and prepares the body to fight or to flee (Huether \& McCance, 2017). The nervous system continues to be wired the same as it was thousands of years ago, with stress hormones being released in response to both real and perceived threats to raise the heart rate, raise the blood pressure, and increase awareness. Although anxiety has many survival benefits in a time of real stress, it can also become problematic if the intensity interferes with life functions (Huether \& McCance).

The APA (2013) defined anxiety as a feeling of unease, tension, and worried thoughts, often associated with uncertain outcomes. Adults commonly experience periods of anxiety from stressors such as a new job, first date, getting married, or starting a new school. The feeling of unease related to the unexpected is common and expected to dissipate once the stressful event is over. Many individuals, however, suffer from more chronic, debilitating anxiety in the form of generalized anxiety disorder, panic disorder, social anxiety disorder, and post-traumatic stress disorder (APA). Anxiety disorders can be caused by many factors, including trauma, violence, abuse, illness, a death of a loved one, environment, and genetics. Some individuals may even find themselves overwhelmed with anxiety in the absence of a stressful event (Merikangas et al, 2010).

The mind-body connection has fascinated medicine for centuries; however, over the past 20 years, more and more evidence has demonstrated how psychological factors 
play a role in health, wellness, illness, and disease. Research has identified the implications of stress on physiology (Kahveci et al., 2014). Stress and anxiety have been widely discussed in the anesthesia literature as surgery itself is known to be one of the most potent activators of the stress response (Paola et al., 2015).

Activation of the sympathetic autonomic nervous system by stress and anxiety initiates the stress response. The stress response includes a number of hormonal changes initiated by the hypothalamic-pituitary-adrenal axis (HPA). The release of adrenocorticotropic hormone (ACTH), cortisol, epinephrine and norepinephrine results in the well-recognized cardiovascular effects of increased heart rate, respiratory rate, increased blood pressure, cardiac output, and cardiac irritability (Paola et al., 2015). Physiological consequences of this stress response may result in problematic anesthesia induction, breath holding, laryngospasm, increased pain, increased requirement of hypnotic medications (Manjunatha et al.,2017), adverse postoperative behavioral changes, and long-term psychological effects (Scully, 2012). Hormonal changes initiated by the stress response have been shown to influence immunologic functions as well.

Delayed wound healing or infection prolong the recovery process and may cause adverse outcomes (Kahveci et al., 2014).

\section{Anxiety in Children}

According to the Centers for Disease Control and Prevention (CDC), 2.6 million children ages 6-17 years in the United States are affected by anxiety or depression (2013). Children experience fears during childhood, including fear of the dark, monsters, and strangers (Fox \& Shaonkoff, 2011). These fears are normal aspects of development and are usually temporary in nature. In contrast, threatening circumstances that 
persistently elicit fear and anxiety predict significant risk for adverse long-term outcomes from which children do not recover easily (Fox \& Shaonkoff). Behavioral neuroscience research in animals has shown that serious, fear-triggering experiences elicit physiological responses that affect the architecture of the brain as it is developing (Clinchy et al., 2011). These experiences cause changes in brain activity and have been shown to have long-term, adverse consequences for learning, behavior, and health (Clinchy et al.).

Parents and caregivers are important and influential people in a child's life and can be a contributor to a child's psychological and emotional development (American Academy of Pediatrics). Parents are often aware of the signs of fear and anxiety in their children and hopefully are present and respond in ways that help calm them and reduce their worry. Doctors' visits have been found to be a common cause of anxiety, with children reporting feeling afraid, anxious, and helpless as they anticipate and engage in healthcare settings with medical professionals. Pediatric patients are reported to visit primary healthcare providers an average of 31 times from birth to age 21 for general wellness visits alone (Weiss \& Elixhauser, 2014). Additionally, 5.9 million United States children experienced hospitalization in 2012; thus, healthcare providers must consider the implications of anxiety in their pediatric patients (Weiss \& Elixhauser). It is important for medical providers to anticipate anxiety and develop appropriate practice guidelines to mitigate anxiety in children. If left untreated, healthcare-induced anxiety and feelings of helplessness coupled with fear and pain can cause significant mental health issues in a child's life. This can result in delayed critical medical treatments, reduced patient 
satisfaction, and at worse cause trauma which can lead to chronic anxiety, major depression, and behavior problems (Lerwick, 2016).

\section{Separation Anxiety}

During the first few weeks of a child's life, there is limited, or no, fear reaction; however as early as four months of age infants will begin to experience stranger anxiety (Miller, Church, \& Poole, 2018). Toddlers and preschool age children may sometimes experience separation anxiety, fear of 'the unknown', fear of heights, of unexpected situations or of the dark. Children younger than eight years old may fear the possibility that something bad may happen to their caregiver or parent, so they prefer to keep them within sight to prevent feelings of abandonment (Miller et al.). Even children nine to 12 years old frequently experience worry during separation from their parent (APA, 2013).

According to the APA (2013), 4\% of children are affected by extreme separation anxiety, with $1.6 \%$ of adolescents also reporting that separation from their parent or caregiver causes acute anxiety. A high prevalence of sub-clinical separation anxiety in children is well documented in the literature and considered a normal part of development in young children (Brazelton, 2006). Separation anxiety has been conducted over time and much research has focused on factors contributing to separation anxiety as a means of identifying areas for intervention to reduce childrens' stress (Purper-Ouakil \& Franc, 2010; Stone, Otten, Soenens, Engels, \& Janssens, 2015).

Stone et al. (2015) sought to identify if, and how, maternal anxiety contributed to anxiety in children at separation from the mother. The study consisted of children aged five to eight who were interviewed; self-reports of separation anxiety and perceptions were also documented. Mothers also completed a questionnaire in which they reported 
feelings of separation anxiety regarding their child. Results showed that maternal separation anxiety was related to dependency-oriented separation anxiety and psychological control concurrently but not longitudinally. Dependency-oriented psychological control was related to separation anxiety in children and maternal separation anxiety both longitudinally and concurrently. The average child reported more separation anxiety at $\mathrm{T} 1$ than $\mathrm{T} 2[\mathrm{t}(284)=4.18, \mathrm{P}<0.01]$, and greater maternal separation anxiety was shown at $\mathrm{T} 1$ than at $\mathrm{T} 2[\mathrm{t}(217)=3.15, \mathrm{P}<0.01)$. The authors found a positive association between maternal anxiety levels and child anxiety levels. A positive trend was found between the separation anxiety in children as well as maternal separation anxiety (beta $=.13, \mathrm{SE}=.90, \mathrm{P}=.05)$ (Stone et al.).

\section{Pre-Operative Anxiety}

Introduction. Any surgical procedure can be described in terms of three distinct phases: preoperative, intraoperative and postoperative. The preoperative phase begins with the decision to have surgery, until the patient is wheeled into the operating room. The intraoperative phase is the surgery itself and ends when the patient is wheeled to the post-anesthesia-care-unit (PACU) (Nagelhout \& Plaus, 2015). Finally, the postoperative phase describes the time immediately following surgery and can be brief, lasting a few hours, or require months of rehabilitation and recuperation.

Preoperative anxiety: definition. Preoperative anxiety, or anxiety regarding impending surgical experience, is a very common phenomenon among adults as well as children (Nagelhout \& Plaus, 2015). Preoperative anxiety in children, specifically, has interested researchers for more than 60 years. Preoperative anxiety is a common reaction that is experienced by many individuals when admitted to the hospital for surgery. It is 
described as an uneasy feeling or an unpleasant state of tension (Nagelhout \& Plaus). Every year, millions of children receive anesthesia and experience fear and anxiety due to the anticipated separation from their parents and pain (Fortier \& Kain, 2015). Fortier et al. (2011) reported that as many children that undergo surgery and anesthesia report significant anxiety. The interval of the preoperative phase can vary as well, from extremely brief, such as in the cases of acute trauma, or longer if the patient has to wait for surgery, undergo preoperative tests, or await the receipt of an organ for transplant. One of the goals of the preoperative phase is to develop a plan to manage the anxiety that may arise (Nagelhout \& Plaus, 2015). Research has demonstrated that preoperative anxiety can affect surgical outcomes, with reports of increased postoperative pain, increased need for analgesia, disturbed sleep, and eating problems (Eckenhoff, 1958; Fortier \& Kain, 2015; Kain, Wang, Mayes, Caramico, \& Hofstadter, 1999; Watson \& Vistram, 2003). Dr. Zeev N. Kain has been recognized as an international expert in the management of perioperative fear and anxiety in children. Kain et al. (1999) found higher levels of preoperative anxiety in children to be associated with a 3.5 times higher risk of postoperative negative behavior. Common behavior problems identified after surgery included bad dreams, waking up crying, disobeying parents, separation anxiety, and tantrums (Kain et al.). More serious behavior changes, such as new onset enuresis, have been reported less often (Kain et al.).

Risk factors related to preoperative anxiety. Different stages of the perioperative process produce anxiety in children for different reasons, i.e. parental separation in the preoperative holding area versus fear of induction mask or pain in the postoperative stage (Fortier \& Kain, 2015). Anxiety from parental separation is common 
for children and their caregivers at the time of surgery. Pediatric surgery can be very stressful and separation from parents can create anxiety and fear in children. Predictors of anxiety such as child temperament, developmental abilities, parental coping, parental pain management attitudes, and parental anxiety appeared to be risk factors for high levels of child anxiety (Fortier \& Kain). Modifiable and non-modifiable variables have continued to be identified in the literature as they contribute to preoperative anxiety in children. Modifiable risk factors associated with increased levels of anxiety in children include longer waiting times between admission and induction time, an increased number of people in the room during induction, and lack of preparation prior to surgery or painful procedures. Non-modifiable risk factors consist of previous negative hospital experiences or children that have been exposed to acute trauma, and children with limited intellectual ability (Lerwick, 2016; Wollin et al., 2003). Fortier et al. (2010) suggested that high parent anxiety and low child sociability were high predictors of perioperative anxiety.

Chow et al. (2017) identified a significant correlation between childrens' preoperative and anxiety and behavioral responses, as well as non-modifiable variables such as temperament, age of the child, anxiety of the parent, and experiences with previous medical encounters. The child's temperamental shyness was explored by using the Colorado Childhood Temperament Inventory. Interestingly, results were contrary to prediction, with increases in childrens' shyness associated with decreases in preoperative anxiety $\mathrm{T} 1(\beta=-10,78 ; \mathrm{P}=.03)$ and at $\mathrm{T} 2(\beta=-12.31 ; \mathrm{P}=.03)$ at both one week prior to surgery as well as immediately before surgery. Chow et al. (2017) postulated that the parents of the shy children may view their children as more vulnerable and thus prepare them for the stressful situation of surgery better than the parents of non-shy children. The 
authors also suggested that perhaps the temperamentally shy children exhibited lower preoperative anxiety because they had developed coping skills in dealing with their persistent anxiety (Chow et al.).

Interventions such as preoperative education, family-centered preparation, improved communication, PPIA, distraction, and support for parent management of recovery at home also target modifiable components of care with the goal of reducing preoperative anxiety in children (Kain et al., 2006; Matziou, Chrysostomou, \& Perdikaris, 2013; Vagnoli et al., 2010).

Preoperative anxiety studies. A group of researchers, Fortier et al. (2010), reported the incidence of, and risk factors for, preoperative anxiety in children as well as associated adverse outcomes such as increased pain and new onset negative postoperative behavioral changes. This specific investigation was conducted to examine perioperative anxiety, or anxiety occurring throughout the pre- and postoperative continuum, as they identified most studies having only examined preoperative anxiety. A total of 261 healthy American Society of Anesthesiology (ASA) physical status I or II, children ages two through 12 who were undergoing general anesthesia for outpatient tonsillectomy and adenoidectomy participated. Perioperative distress was measured with the Modified Yale Preoperative Anxiety Scale (mYPAS) and the Visual Analog Scale (VAS); these measurement tools for preoperative anxiety in children have been validated and have demonstrated a good to excellent inter- and intra-observer reliability. The numeric 0-10 rating scale (NRS) for overall child anxiety, as well as the Parents' Postoperative Pain Measure (PPPM), which reflects behavioral changes that correspond to pain, were utilized. Additionally, researchers used the EASI instrument of child temperament 
(EASI), a widely used parent-report measure. The Child Behavior Checklist (CBCL) was used to identify the internalizing and externalizing problems in children and the Post Hospitalization Behavioral Questionnaire (PHBQ), was used to measure posthospitalization behavioral changes in children. Finally, the State-Trait Anxiety Inventory (STAI), which is a self-report measure, was used to evaluate parental situational (state) and general (trait) anxiety.

Fortier et al. (2010) recruited participants 7-10 days before surgery, during their preoperative preparation visit. Childrens' anxiety was measured on the day of surgery via VAS and mYPAS in the preoperative holding area, at separation from parents, upon entering the operating room, and during the introduction of the anesthesia mask. Parental anxiety was measured in the preoperative holding area and at separation from the child. Anesthesia induction followed standard protocol and no pre-medications for anxiety were administered. Childrens' immediate postoperative anxiety was measured via VAS at arrival to the PACU and at designated intervals after that. Pain management was standardized in the PACU; following discharge, child anxiety was measured by parent completed NRS on postoperative days 2, 3, 7, and 14 (Fortier et al.).

Results illustrated child anxiety increasing significantly prior to surgery $(\mathrm{F}[1,223]$ $+382.47, \mathrm{P}<0.001)$, peaking at mask introduction, decreasing in the immediate postoperative setting $(\mathrm{F}[1,184]+534.81, \mathrm{P}<0.001)$, and over the two weeks at home $(\mathrm{F}(1,188)+183.54, \mathrm{P}<0.001)$. Anxiety was significantly and positively correlated with pain within the first 24 hours after surgery $(r=0.26, \mathrm{P}=0.004)$ and new onset-negative behavioral changes in the two weeks following surgery $(\mathrm{r}=0.25, \mathrm{P}=0.006)$. Parental anxiety and child temperament appeared to be risk factors for high levels of anxiety in 
children throughout the perioperative setting. Age, gender, previous surgeries or hospitalizations, EASI, and CBCL were examined as predictors of perioperative anxiety in children while age, income, and STAI were parent factors compared. The researchers found that even when controlling for child sociability, high parent anxiety at separation remained a significant predictor of high perioperative anxiety (Fortier et al., 2010). There is valuable literature describing preoperative anxiety in children but there is lack of data referencing children's perioperative anxiety.

A more recent study by Charana et al. (2018) examined the effect of specific demographic characteristics in parents' and childrens' preoperative anxiety. The study consisted of 128 Greek speaking children ranging 1-14 years of age. Anxiety was measured using the STAI and m-YPAS scales. Significant positive correlations were observed between the STAI-trait anxiety scores and m-YPAS $(r=0.286, \mathrm{P}<0.001, \mathrm{~m}-$ YPAS and STAI-state anxiety scores $(\mathrm{r}=0.493, \mathrm{P}<0.001)$, and STAI-state anxiety scores were much higher than STAI-trait anxiety scores $(r=0.303, P=0.001)$. Predictors of increased anxiety levels in parents were the child's gender and age, high or low education level, being a mother, living in rural areas, and high baseline parental anxiety. In addition, younger parents showed more anxiety than older parents and mothers showed more anxiety than fathers. The main determinants of preoperative anxiety in children consisted of the lack of premedication, previous hospitalizations, high parental anxiety, and being an only child. The study identified the most common risk factors for preoperative anxiety was the child's age, no premedication, high situational parental anxiety, education level, previous hospitalizations, and living in rural areas. Identifying 
those characteristics can help control anxiety and implement interventions to control anxiety levels (Charana et al.).

\section{Preoperative Anxiety Management in Children}

Pharmacologic management of preoperative anxiety. Studies investigating possible ways to decrease preoperative anxiety have increased and have focused on interventions such as PPIA, preparation programs, and sedative premedication (A1Yateem, Brenner, Shorrab, \& Docherty, 2016; Kurdi \& Muthukalai, 2016; Scully, 2012). Sedative medications are classified as central nervous system (CNS) agents and sedatives and narcotic analgesics are among the most common medications used during surgery (Nagelhout \& Plaus, 2015). Sedatives such as benzodiazepines are used to produce a calming or tranquilizing effect and help to reduce anxiety, stress or excitement (Flood, Rathmell, \& Shafer, 2015).

Midazolam, a benzodiazepine, works by enhancing the activity of the inhibitory neurotransmitter gamma-aminobutyric acid (GABA) in the brain, resulting in sedative, hypnotic, anxiolytic, anticonvulsant, and muscle relaxant properties (Flood et al., 2015). Midazolam is a common medication used in anesthesia, administered preoperatively to decrease anxiety, induce sleep, and cause a loss of ability to create new memories (Nagelhout \& Plaus, 2015). Sedatives can also cause side effects such as respiratory depression or airway obstruction, which can prolong recovery times and cause adverse effects (Flood et al., 2015).

Clonidine, an anti-adrenergic cardiovascular agent, is used to treat high blood pressure, attention deficit hyperactivity disorder, anxiety disorders, tic disorders, withdrawal, migraines, and certain pain conditions (Brayfield, 2014). In anesthesia, 
clonidine has been used to cause drowsiness and sedation. By stimulating alpha-two receptors in the brain stem, peripheral vascular resistance is decreased, reducing blood pressure and the sympathetic nervous system's response to tachycardia and hypertension associated with anxiety (Flood et al., 2015). Clonidine has been used in the management of preoperative anxiety in children. Dexmedetomidine is another CNS agent similar to clonidine in anti-adrenergic properties that has been used to treat preoperative anxiety in children. In addition to its anxiolytic properties and effect on the activity of GABA, a unique feature of Dexmedetomidine is that it has analgesic properties but is opioid sparing, and thus not associated with respiratory depression (Flood et al.).

A double-blinded, randomized controlled study conducted by Kumari et al. (2017) compared the efficacy of oral midazolam, clonidine, and dexmedetomidine in pediatric patients undergoing ophthalmic surgery. Ninety children, aged 4-12, were randomly placed and evenly distributed in one of three groups comparable in gender, weight, and age. Patients were evaluated for anxiolysis, sedation, changes in blood pressure, and heart rate before surgery in the preoperative room. Baseline vital signs, oxygen saturation, anxiety, and sedation were monitored and rechecked every fifteen minutes until being brought to the operating room. Childrens' behavior during separation from their parents, mask acceptance, sedation, anxiety and behavior were assessed using a point scale.

The groups were comparable in gender, age, and weight. Group M received oral midazolam $0.5 \mathrm{mg} / \mathrm{kg}$ body weight; Group D received oral dexmedetomidine $4 \mathrm{mcg} / \mathrm{kg}$ body weight, and Group C received oral clonidine $4 \mathrm{mcg} / \mathrm{kg}$ body weight. Their baseline anxiety scores were comparable in all groups $(\mathrm{P}=0.483)$ and the mean anxiety score at 60 minutes was significantly reduced with midazolam as compared to clonidine and 
dexmedetomidine groups. The group $\mathrm{M}$ and group $\mathrm{D}$ were similar in regard to behavior during separation from parents $(\mathrm{P}=0.236)$. Group $\mathrm{D}$ was superior to group $\mathrm{C}(\mathrm{P}=$ 0.031), and Group $\mathrm{C}$ was comparable to group $\mathrm{M}(\mathrm{P}=0.46)$. However, Group $\mathrm{M}$ showed a greater number of children having an easier time with separation from their parents when compared to Group D and Group $\mathrm{C}(\mathrm{P}=0.028$ and $\mathrm{P}=0.012)$. The results showed that oral midazolam provided higher sedation when compared to clonidine and dexmedetomidine $(\mathrm{P}<0.001)$. The onset of sedation and mean anxiety scores were less with midazolam and greater with both clonidine and dexmedetomidine. All three groups were comparable regarding satisfactory mask acceptance $(\mathrm{P}=0.163)$, and there was no significant difference in the incidence of side effects between the groups (Kumari et al., 2017).

Considering side effects and potential negative outcomes associated with sedatives used to reduce preoperative anxiety in children, research has compared the use of midazolam to the use of non-pharmacological interventions. In a randomizedcontrolled trial performed by Seiden and colleagues (2014), preoperative anxiety was evaluated among children receiving oral midazolam compared to an electronic tabletbased interactive distraction (TBID) tool. The study consisted of 108 children, aged 1-11 years old. Children were randomly selected by a sealed envelope and grouped within one of two groups, either TBID or oral midazolam. The oral midazolam group received 0.5 $\mathrm{mg} / \mathrm{kg}$ of the medication, $20 \mathrm{mg} \max , 15-45$ minutes before inhalation induction. Children assigned to the TBID group were allowed to select an age-appropriate video game which they could play at the time of induction. 
The results of this study demonstrated a statistically significant difference in the increase of anxiety at parental separation between the TBID group compared to the midazolam group. Parental perception of anxiety with 30 parents at separation in the TBID group stated their child was not anxious during separation when compared with only 15 in the midazolam group. The mean difference $(95 \% \mathrm{CI})$ on anxiety during induction was remarkable between the TBID and midazolam groups. An increase in anxiety during parental separation between the TBID and the midazolam group was -9 (2.6 to $-16.40, \mathrm{P}=0.006$ ), showing superiority to the midazolam group. Children $2-11$ years old showed that a mean difference in anxiety at induction was remarkable between the TBID and midazolam group, -14.0 (-6.1 to $-22,0), \mathrm{P}<0.001$. Use of the TBID tool was associated with a reduction in perioperative anxiety, increased parental satisfaction, decreased emergence delirium, and quicker time-to-discharge when compared to the midazolam group. Results suggest that the TBID tool can be an effective strategy to minimize anxiety in children undergoing surgical procedures (Seiden et al., 2014).

\section{Nonpharmacological management of pre-operative anxiety: introduction.}

Given the disconcerting aspects of pharmacological management of preoperative anxiety in children, non-pharmacological interventions are increasingly being used to assist in the induction of general anesthesia (Fortier \& Kain, 2015; Wright et al., 2007). Nonpharmacological methods are used to encourage cooperation and reduce preoperative anxiety and may include methods such as PPIA, music therapy, interaction with video games, cartoons, or clown doctors. Elaborate interventions, necessary technology, or time-intensive preparation programs have proved to be too costly (Kain et al., 2010) while other distraction techniques and non-pharmacological interventions are little to no 
cost. The preoperative phase of surgery involves planning and preparation and must consider both the physical, as well as the psychological, state of the patient and support system.

\section{Preparation Programs}

Preoperative preparation programs are educational group programs that help children and their caregivers prepare for anesthesia. The purpose is to give children the opportunity to ask questions, look at equipment, and engage in interactive play prior to surgery.

Kain and colleagues (2007) developed a perioperative preparation program called ADVANCE, which incorporated the standard of care with anxiety reduction techniques, distraction on the day of surgery, video modeling education, parental presence, coaching of parents, and induction mask practice. Participants included 480 healthy children aged 2 through 12 years undergoing elective, outpatient surgery. The control group received the standard of care, with no premedication and no parental presence. The parental presence group received the standard of care and additionally parents were allowed to be present during induction of anesthesia. The ADVANCE group received standard of care treatment plus the family-centered behavioral preparation program, and the medication group received standard of care plus oral midazolam $0.5 \mathrm{mg} / \mathrm{kg}$ at 30 minutes before the separation of parent and child to the operating room.

The primary outcome measured was childrens' perioperative anxiety, which was assessed using the mYPAS. The secondary outcome measured was parent anxiety, which was assessed using the STAI. Trained observers assessed for emergence behavior, PACU 
analgesic administration documentation, and documentation of the time between arrival to the PACU and discharge home respectively (Kain et al., 2007).

The study protocol consisted of a preoperative visit for all groups five to seven days before surgery. At this time, the mYPAS was administered and participants were randomized into one of the four groups. On the day of surgery in the preoperative holding area, parents in all groups completed the STAI and children were assessed using the mYPAS. Children in the control and parental presence group received standard of care during this time. Children in the midazolam group received $0.5 \mathrm{mg} / \mathrm{kg}$ midazolam at 30 minutes before entrance to the operating room. Children in the ADVANCE group received a bag of distracting age-appropriate toys (puzzles, brain teasers, pop-up books, art supplies, a pinwheel) for the children to play with while waiting in the holding area (Kain et al., 2007). During induction of anesthesia, parents in the parental group and the ADVANCE group accompanied their children to the operative room for induction. The control group and medication group parents were separated from their children outside of the operating room doors. All children were videotaped throughout the induction process so the mYPAS could be rated.

Using two-way repeated measures of variance analysis, mYPAS scores for each group were found to be dependent on time of the assessment (baseline, holding area, introduction of mask). Comparison of mYPAS scores between groups indicated the children in the ADVANCE group were significantly less anxious than those in the control, parental presence, or midazolam group while in the holding area (31 +/- 17 vs. 36 +/- 16, vs. $35+/-16$, vs. $37+/-17 ; P=0.001)$. Significant group differences were found when anxiety scores were obtained during induction of anesthesia $(F=4.2, P=0.006)$. 
Further post hoc tests showed that the anxiety of children in the ADVANCE group was significantly lower than that of the children in the parental presence and control groups $(43+/-23$ vs. $50+/-26$, vs. $52+/-26)$ and similar to the anxiety level of children in the midazolam group (40+/-24) (Kain et al., 2007). Compliance and anxiety during the induction of anesthesia was similar in the midazolam and ADVANCE groups. Although, children in the ADVANCE group required less analgesia and had decreased incidence of emergence delirium (Kain et al.).

This study was valuable in that it demonstrated that a family-centered preoperative behavioral program not only reduced childrens' anxiety before surgery and at induction, but also reduced the incidence of postoperative delirium, shortened discharge time after surgery, and reduced analgesic consumption of fentanyl after surgery by half. It is unclear whether benefits of the ADVANCE program would outweigh costs when controlling for negative outcomes, analgesic consumption, and delays in discharge related to midazolam.

\section{Parental Presence and Distraction Management}

Parental presence at the induction of anesthesia (PPIA) has been in practice for decades. It allows parents to stay with their child prior to the induction of anesthesia to reduce anxiety levels. This policy typically allows one parent to accompany the child into the operating room and the parent must follow direction from the medical personal (Kruger \& Rosen, 2016).

Matziou et al. (2013) investigated the effect of parental presence and distraction with a toy in children requiring a vein puncture. Although, it did not discuss parental presence during induction of anesthesia it did focus on parental presence as a distraction 
method during painful procedures. The aim was to find out if children had more or less pain using the two methods of distraction. The study consisted of two experimental groups and one control group: the parental presence group, the toy group, and the control group. Children were assessed and measured by a verbal pain scale, the State-Trait Anxiety Inventory for Children (STAIC), and the measurement of vital signs. The parental presence group had a parent accompany them during the painful intervention. Mothers were most often present during the procedure rather than fathers. The parent was told not to make reassuring comments or try to distract the child. The second group was given a toy kaleidoscope before the start of the procedure. The toy was given to the child by a volunteer play therapist and encouragement to play with the toy during the procedure. The last group was the control group that was not provided a toy or accompanied by a parent.

Children with parents showed a noteworthy reduction in mean blood pressure, respirations, and pulse. Children in the parental presence group had 19.7 breaths per minute after the painful procedure, the toy group had 21.1 breaths per minute, and the control group 23.2 breaths per minute $(\mathrm{P}<0.001)$. Pulse rates were 68.3, 69.6, and 72.9 beats per minute in the three groups respectively $(\mathrm{P}<0.01)$. Systolic and diastolic blood pressures were lower in the parental presence group when compared to the other two groups $(\mathrm{P}<0.05)$. There was a reduction in pain when a parent was present (the parental presence group $=2.00$; toy group +3.09 ; the control group $+5.53, \mathrm{P}<0.001$ ). Stress was decreased in the parental presence group $(\mathrm{P}<0.001)$. The score of stress A-State scale was reduced when parents were present as well as when the toy kaleidoscope was used. The intensity of pain was also decreased when the parent remained with child as well as when 
the kaleidoscope was played with. Results showed that children with parental presence had the best outcomes (Matziou et al., 2013).

Although current literature on parental presence and childrens' preoperative anxiety demonstrates mixed results, PPIA has been incorporated into most preparation programs (Fortier \& Kain, 2015; Kain et al., 2007). Parental presence at anesthesia induction is becoming more common practice (Fortier \& Kain, 2015; Matziou et al., 2013). Results from surveys of parents and professionals' attitudes regarding PPIA also suggest that most parents prefer to be present during their child's induction (Fortier \& Kain, 2015; Matziou et al., 2013). Regardless of the suggested advantages and/or disadvantages, parents have a right to be present at their childs' anesthesia induction. Literature examining parental presence and children's preoperative anxiety should focus on identifying variables associated with positive and negative parental presence outcomes. Identification of variables contributing to reduced parental and child preoperative anxiety when the parent is present for induction could then inform interventions to improve the use of PPIA as a more reliable tool to reduce preoperative anxiety in children. The focus of this integrative review is to explore the impact of PPIA on pediatric patient's anxiety during the operative experience and will be addressed in results.

Next, the theoretical framework that guided this paper will be reviewed. 


\section{Theoretical Framework}

The theoretical framework that was used to guide this research project is Peplau's Theory of Interpersonal Relationships, as illustrated in Figure 1 below.

\section{Peplau's Theory of Interpersonal Relationships Factors influencing orientation phase}

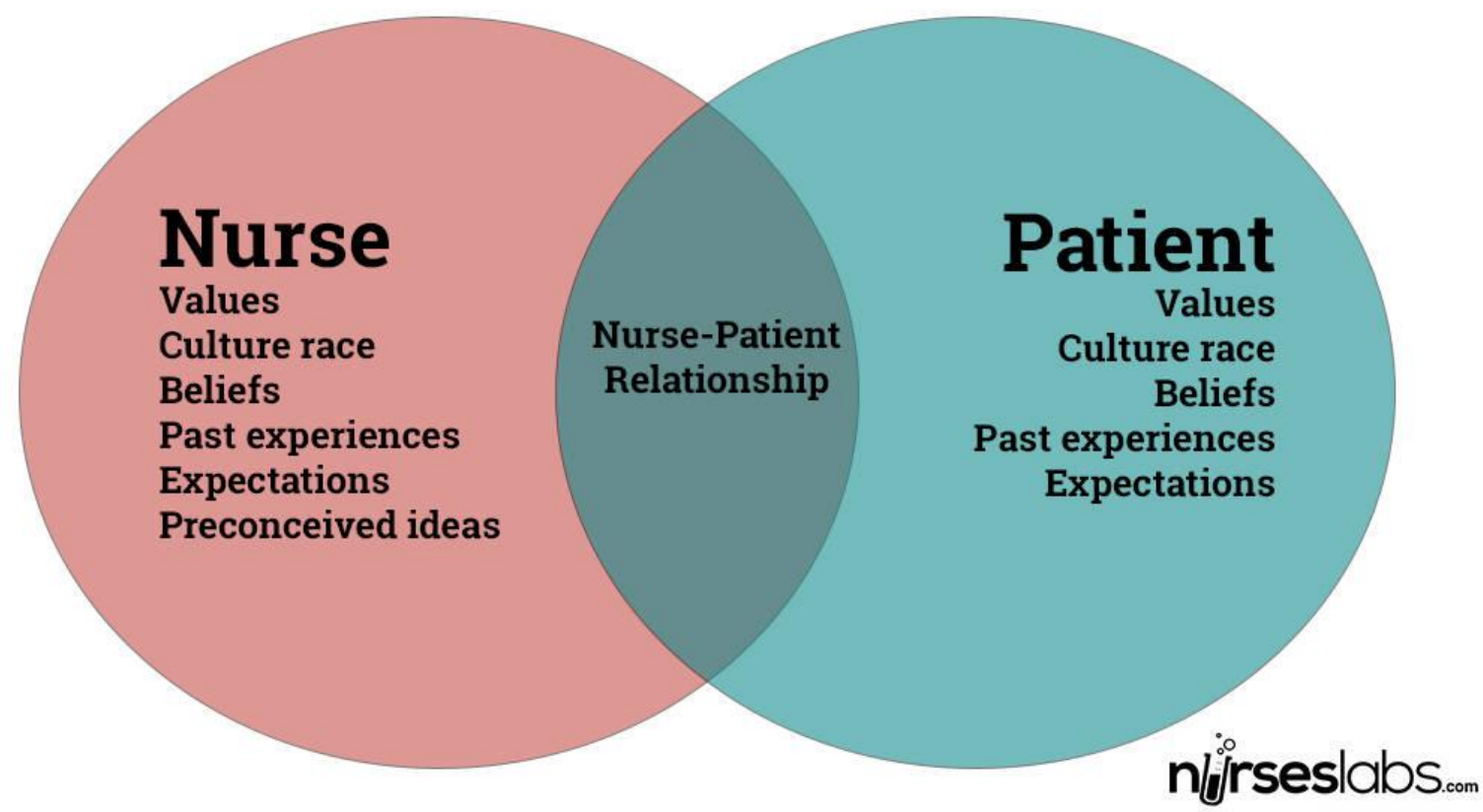

Figure 1. Peplau's Theory of Interpersonal Relationships.

Peplau's Theory of Interpersonal Relationships helps to guide the topic of examining the effects of anxiety during anesthesia in children. Peplau based her nursing theory on Sullivan's theory, the Interpersonal Theory of Psychiatry. Using Sullivan's concept of degree of anxiety, Paplau developed four levels of anxiety (McEwen \& Willis, 2014). The anxiety levels experienced by patients are mild, moderate, severe, and panic. Peplau believed that nurses could help ease patients' anxiety levels. The theory focused on nursing as a "healing art" and the benefits of therapeutic patient-nurse relationships. 
Concepts and principles that support relationships in nursing practice establish care through learning and personal growth (Gurgel, Tourinho, \& Monterio, 2014). Peplau emphasized the nurse-client relationship as a foundation of nursing practice (Peplau,1997).

Peplau's theory is a middle range descriptive classification. The Theory of Interpersonal Relations is also referred to as psychodynamic nursing, which is the understanding of one's behavior. The theory focuses on the patient's feelings, needs, behavior and problems (McEwen \& Willis, 2014). This nursing model identifies four sequential phases in the interpersonal relationship: orientation; identification; exploitation; and resolution. The orientation phase is when the patient and nurse first become acquainted with each other. It is important for a professional relationship to be established that is ultimately patient-centered. Trust begins to develop at this time and the nurse begins to think of the patient as a unique individual (Clarke, 1999). The patient feels the nurse genuinely cares. Identification is the second phase when the patient feels supported and a decrease in hopelessness. The patient expresses their feelings and feels secure. Next is exploitation, when the nurse assists the patient. Interview techniques are used in this phase to understand, explore, and competently deal with the issue. The nurse supports and assists with the needs of the patient. Lastly, is resolution, which is the final phase, when the patient/client no longer needs professional nursing services. It is also known as termination on the nurse-patient relationship (Peplau,1997).

According to Peplau, theories of interpersonal relations are particularly relevant for healthcare workers. She found that the interaction phenomena which occurs between a care provider and a patient have a qualitative impact on patient outcomes (Nystrom, 
2007). Peplau's model describes the importance of nurse-patient relationships and how the two are linked together for ideal patient outcomes. Peplau's Theory of Interpersonal Relationships provides an excellent framework to ensure the patient's needs are being fulfilled and carried out for optimal health care and reduction of anxiety. The scope of the theory is relatively broad but narrowed down with the use of the four levels used to address anxiety. This theory is useful and can reflect real-life situations of patient's experiences to preoperative anxiety and how positive nurse-patient relationships may have a positive impact on patient outcomes.

Next, study methods will be reviewed. 


\section{Method}

\section{Purpose}

The purpose of this paper was to explore the impact of parental presence on pediatric patients' anxiety during the operative experience.

\section{Design}

The type of design selected for this project was an integrative review. An integrative review was chosen to summarize the past empirical and theoretical literature to provide a more comprehensive understanding of the particular phenomenon or healthcare problem (Whittemore \& Knafl, 2005). Whittemore and Knafl's article, "The Integrative Review: Updated Methodology" was be used to guide this integrative review.

\section{Inclusion/Exclusion Criteria}

Inclusion criteria for this integrative review involved (a) subjects ages 2-18; (b) surgical patients who have undergone major or minor surgeries, inpatient or outpatient, emergency and non-emergency surgeries; (c) studies that measured anxiety by physiological or psychological factors; (d) must include parental presence during anesthesia (PPIA); (e) quantitative studies conducted in preoperative, postoperative and perioperative settings; (f) studies and evidence-based reviews written in English; and (g) within the last 8 years: from 2010 to 2018 .

Articles that were excluded from this review included: (a) ages greater than 18; (b) settings other than the preoperative, postoperative and perioperative setting; (c) literature greater than eight years; (e) articles in foreign languages. 


\section{Search Strategy}

A comprehensive literature review was accomplished by utilizing the internet and searching databases such as Cumulative Index to Nursing and Allied Health Literature (CINAHL) and PubMed. The ancestry approach was used with various articles to develop the search. A generalized examination was done using the keyword "parental presence' and then a narrowed search using additional key words such as 'preoperative anxiety'. The following keywords were used to search for articles: anxiety; preoperative; children; pediatrics; anesthesia; parental presence; PPIA; and distraction. A final advanced search was incorporated with the inclusion and exclusion criteria and references from 2010-2018. Any duplicate studies were removed and articles were screened again for eligibility.

The PRISMA flow diagram (Moher, Liberati, Tetzlaff, \& Atman; 2009) was used in the search strategy when conducting this integrative review to document the retrieval and selection process. The PRISMA flow diagram (Figure 2) was also used to show the actual search path and illustrates the final selection of articles for inclusion. 


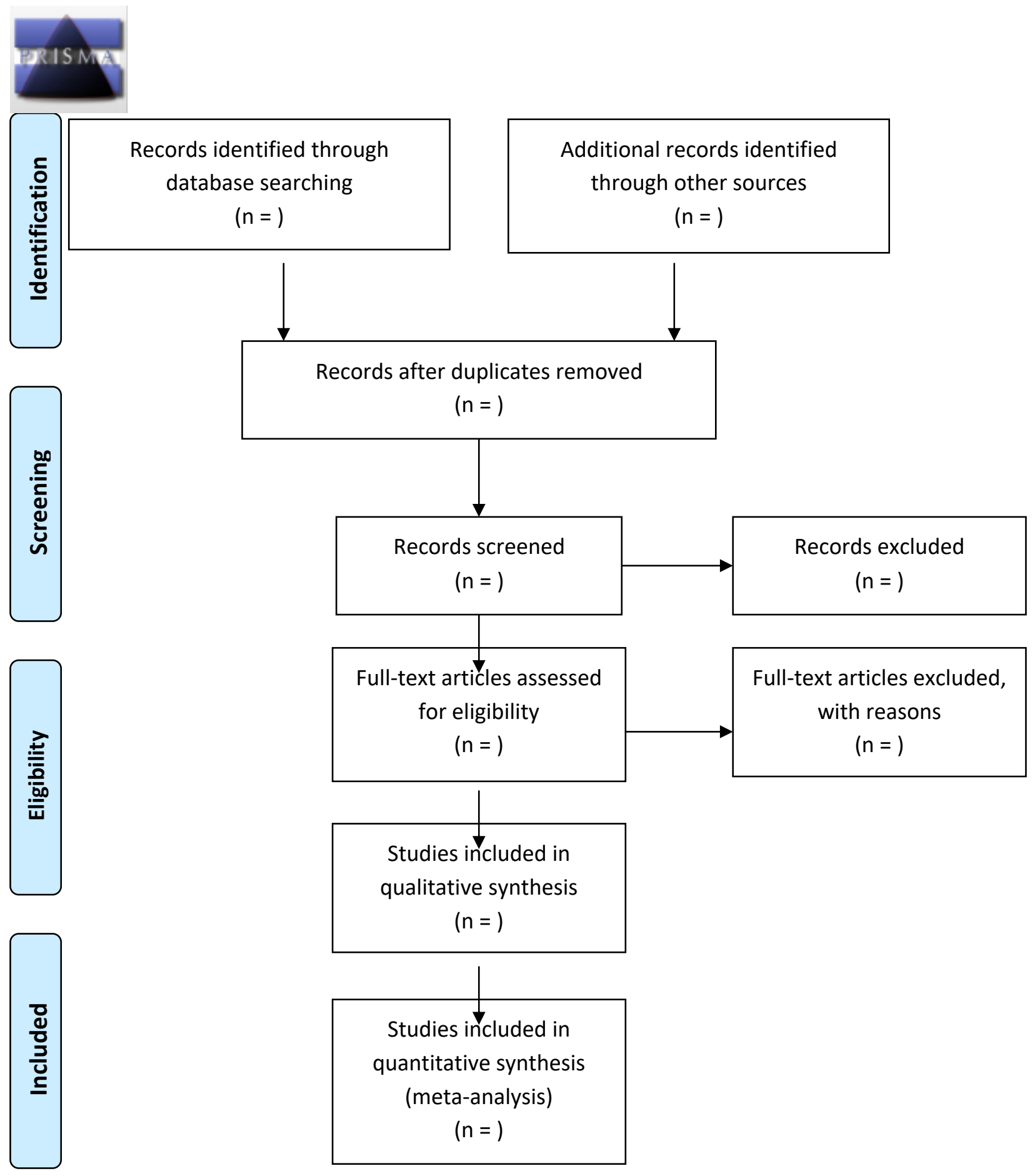

Figure 2. PRISMA Flow Diagram. 


\section{Data Collection Plan and Critical Appraisal}

Polit and Beck's (2017) guide to an overall critique of qualitative and quantitative research was used to critically evaluate articles in the integrative review and assess the quality. Using the Polit and Beck guide to critique quantitative articles, questions were used that include the title, abstract, introduction, method, and discussion. The method section of the articles were appraised by investigating protection of human subjects' rights, sample and population, research design, measurement and data collection, interventions, data analysis, and findings. Within the discussion section, the findings and implications were analyzed and reviewed. Qualitative research was not included in this integrative review. The Polit and Beck (2017) guideline for a literature review was also used in this integrative review. In keeping within the guidelines, the literature review was critiqued in sections which included whether or not the review was though, if it relied on primary source research articles, if it was critically appraised and compared key studies, if it was well organized, if it used appropriate language, and if it was part of a research report for a new study.

\section{Cross-Study Analysis}

A cross-study analysis was performed to examine the reviewed literature for common themes. Comparisons were conducted to examine the key findings and recommendations across the studies that are included in this integrative review.

Next, the results will be discussed 


\section{Results}

After duplicates were removed, 144 articles were found to be worthy for further review based on database searching. One hundred and four records were screened after excluding articles/studies based on inclusion and exclusion criteria. Apprasial led to a full text review of 14 articles. Eight studies were excluded for reasons such as not being pediatric studies that focused specifically to a childs' anxiety during induction of anesthesia. Six articles met inclusion criteria and were included in this integrative review. The flow path is illustrated on the next page (Figure 3). 

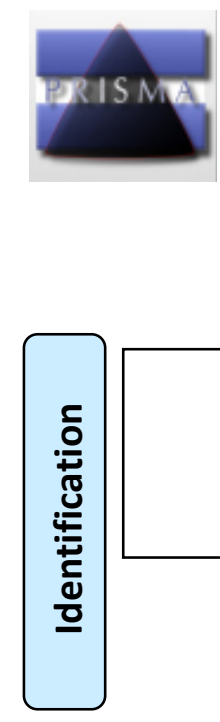

$$
\text { Records identified through }
$$
database searching

$$
\text { ( } n=158)
$$

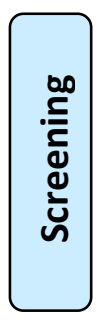

Records after duplicates removed
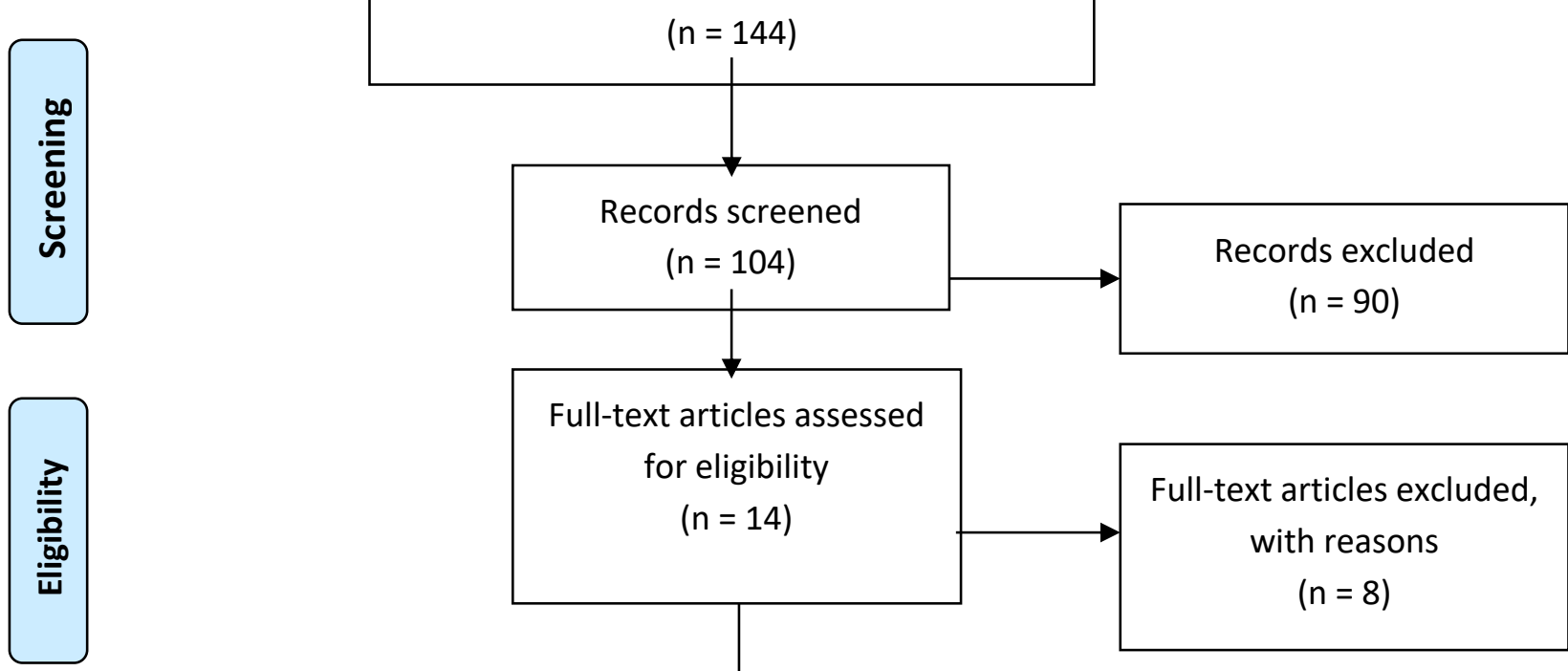

Studies included in integrative review

$$
(n=6)
$$

Figure 3. PRISMA Flow Diagram. 
Chundamala Wright, and Kemp (2008) (Appendix A-1) conducted an evidencebased review that examined the effects of parental presence during the induction of anesthesia (PPIA) on parents' and children's anxiety. Fourteen studies were included that consisted of one retrospective comparative study, four prospective comparative studies, and nine randomized control trials (RCTs). The years of publication of articles ranged from 1988 to 2006 . Ten studies analyzed the parents' anxiety and did not show parental presence to be any more beneficial than not having parental presence, using midazolam alone, parental presence plus a video game, or parental presence plus midazolam. Three studies evaluated parental presence during anesthesia induction in relation to parents' anxiety. One of those studies measured parents' anxiety using the visual analogue scale (VAS) while two of the studies had children placed in either a treatment group that provided parents at induction of anesthesia or the control group which did not have a parent present. They both assessed parental anxiety using the State Trait Anxiety Inventory (STAI). Both studies did not show a significant difference between the treatment and control groups.

Eleven studies explored by Chundamala et al (2008), focused on childrens' anxiety during the induction of anesthesia. Nine studies compared parental presence to no parental presence. Five studies found no difference between the two; two studies showed parental presence had better results but one of the studies relied on the parents' reports on the child's anxiety which could sway the results and cause bias. Two studies showed mixed results. One study compared parental presence alone to parental presence with a handheld video game which the distraction of the video game showed to lessen the child's anxiety. Several studies also compared parental presence to premedication 
midazolam which had mixed results. Three studies compared parental presence alone to parental presence with premedication midazolam. One study showed no difference between the two groups, one showed mixed results and the third found superior results in the parental presence plus midazolam when compared to parental presence alone.

Next, ten studies evaluated parents' anxiety, nine of those studies compared no parental presence (comparison) to parental presence (intervention). Six studies showed no difference between the two groups. Two studies found mixed results while one study found parental presence had more positive outcomes than without parental presence. Many of the studies examined parents' anxiety by comparing parental presence to premedication with the sedative midazolam. Two studies showed mixed results while another study showed parental presence plus midazolam compared to midazolam alone had better outcomes.

Many of the studies compared sedative premedication of midazolam with parental presence in correspondence to childrens' anxiety. Most of the studies showed mixed results while others found midazolam plus parental presence showed better results than parental presence alone. Another study found that parental presence plus a hand-held video game lessened the child's anxiety. In conclusion, contrary to popular belief, in most cases parental presence did not appear to benefit the childs'or the parents' anxiety. Premedicating children with midazolam has been a viable alternative and distraction tools such as video games can be an appropriate alternative.

A prospective study conducted by Vagnoli et al. (2010) compared the effectiveness of using PPIA, therapeutic clowns, or sedative premedication to reduce 
preoperative anxiety in children (Appendix A-2). Seventy-five subjects were randomly assigned to one of three groups. The first group was accompanied in the preoperative room by two clowns and a parent. The clowns used various methods to entertain the child, including magic tricks, gags, music, games, puppets, word games, and soap bubbles. The children interacted with the clowns before entering the operating room and the clowns and parent stayed with them throughout the anesthesia induction. The second group of children were premedicated with $0.5 \mathrm{mg} / \mathrm{kg}$ of oral midazolam at least 45 minutes before the surgical procedure began. They too had a parent present in the operating room. The third group was the control group in which the children were accompanied in the operating room by one parent, without any clowns, pre-medications, or other distractions. The m-YPAS was used to evaluate the childrens' behavior in the waiting room and at induction of anesthesia in the operating room. Parental anxiety was assessed using the STAI; potential scores ranged from 20 to 80, with the higher scores indicating greater anxiety. Group differences were analyzed using a one-way analysis of variance (ANOVA) and pair wise multiple comparisons were performed with the Scheffe test. Pearson's correlation coefficient was used to evaluate any possible relationship between demographic characteristics and the child's age, anxiety, and parental anxiety. Each group showed increased anxiety during the induction of anesthesia $\left(F_{(2,72)}=12.994\right.$; $P=0.001)$; however post hoc Scheffe test identified a significant reduction in the anxiety of the clown group compared to the premedication group $(P=0.015)$ as well as the control group $(P=0.000)$. The authors concluded that using clowns and PPIA as interventions to reduce anxiety were more effective than PPIA alone, or PPIA with oral midazolam (Vagnoli et al., 2010). 
The results are consistent with those of other studies comparing the use of midazolam to alternative interventions such as music therapy (Kain et al., 2004). No significant differences in anxiety scores were found between the parents attending the induction of anesthesia, possibly indicating that the clown intervention had no effect on parental anxiety. Furthermore, the correlations between the anxiety level of the children and that of the parents were not significant. Teasing apart the interacting variables contributing to parental and child preoperative anxiety would be beneficial to identifying effective interventions (Kain et al., 2004).

A study conducted by Rasti, Jahanpour, \& Motamed (2014) (Appendix A-3) examined the effect of parental presence on anxiety levels during the induction of anesthesia. The clinical trial examined 60 children aged 2-11 years old who were assigned randomly to an experimental group or a control group. Childrens' anxiety was measured using the m-YPAS scale, the data collected was analyzed using descriptive statistics and chi-square test, paired t-tests, and Fisher's exact test. There was no significant difference between the Chi-square test and Fisher's exact between the experimental and control group in terms of age $(\mathrm{P}=0.2)$ birth order $(\mathrm{P}=0.3)$ the attendant parent $(\mathrm{P}=0.2)$, mothers' education level $(\mathrm{P}=0.5)$, fathers' education level $(\mathrm{P}=0.9)$, type of surgery $(\mathrm{P}=0.5)$, and place of residence $(\mathrm{P}=0.054)$. The two groups were different in terms of irritation or anxiety $(\mathrm{P}=0.03)$ and dependence on parents $(\mathrm{P}=0.03)$.

The Chi-test did not show a significant difference between expression of emotions $(\mathrm{P}=0.6)$, activity $(\mathrm{P}=0.6)$, and tone of voice $(\mathrm{P}=0.6)$. The $\mathrm{t}$ test showed no difference between control $(70.39 \pm 20.93)$ and environmental groups $(67.83 \pm 16.78)$ or mean total score for children's anxiety before the operation $(\mathrm{P}>0.05)$. The results showed no 
statistically significant difference between children's anxiety scores in the experimental group (-8.39 \pm 22.95$)$ and in the control group $(-3 \pm 16.45)$. Parents accompanying their child during induction of anesthesia did not have any effect on the anxiety in children in the control and experimental groups. The authors stated that further studies may enhance validity of the obtained results and more effective interventions should be used to reduce anxiety in children undergoing surgical procedures (Rasti et al., 2014).

A study conducted by Jahanpour, Rasi-Emad-Abadi, Naboureh, Nasiri, and Motamed (2017) (Appendix A-4) investigated the effects of PPIA on preoperative anxiety in children as well as their parents. Sixty children participated in the clinical trial, including children aged 2-10 years who underwent minor-medium elective surgeries requiring general anesthesia and their parents. Researchers contacted parents if their child met the inclusion criteria. Children were randomly assigned groups based on type of surgery and age group; groups included the parent absent group $(\mathrm{n}=30)$ or the parent present group $(\mathrm{n}=30)$. The control group was taken to the operating room alone while the intervention group was accompanied by a parent.

The Modified-Yale Preoperative Anxiety Scale (M-YPAS) was used to measure the childrens' preoperative anxiety. The scale has good reliability and validity for measuring anxiety in children during the preoperative phase. The parents' anxiety was assessed using the Spielberg State-Trait Anxiety Inventory (STAI).

Children in the control group and intervention group were aged $5.81 \pm 2.32$ and $5.11 \pm 2.30$ years respectively and were similar in their baseline characteristics and age. A Chi-square test indicated no significant difference between the groups in vocalization 
$(\mathrm{P}=0.632)$, activity $(\mathrm{P}=0.601)$, and emotional expression $(\mathrm{P}=0.612)$. Differences were observed between the two groups in use of parents $(\mathrm{P}=0.056)$ and state of arousal $(\mathrm{P}=$ 0.033). Results showed no significant difference between the control and intervention group regarding trait $(\mathrm{P}=0.826)$, state $(\mathrm{P}=0.056)$, and total $(\mathrm{P}=0.208)$ anxiety in parents. It also did not show a significant difference in the parents' anxiety between the intervention group (79.23) and the control group (85.86). The mean score of parents' and childrens' anxiety was not different between the two groups.

Sadeghi, Khaleghnejad, Mahdavi, Salarian, and Sajjad (2016) conducted a randomized control trial in pediatric patients aged 4-10 years who underwent minor surgery (Appendix A-5). The sample size was calculated based on the results of a pilot study of 30 patients, similar studies, and a sample size formula $(\alpha=0.05, \mathrm{P}=0.5, d=0.1)$, which specified that at least 96 pediatric patients were needed. Randomization was used to allocate the selected participants into the control and PPIA groups. Patients in the control group received $0.5 \mathrm{mg} / \mathrm{kg}$ oral midazolam 20 minutes prior to surgery; patients in the PPIA group received $0.5 \mathrm{mg} / \mathrm{kg}$ oral midazolam and PPIA and anxiety in children was assessed using the modified Yale Preoperative Anxiety Scale (mYPAS) and cooperation with the anesthesiologist was assessed using the Induction Compliance Checklist (ICC). Parental satisfaction was assessed using the visual analog scale (VAS), parental anxiety was assessed using the State and Trait Anxiety Inventory (STAI) tool, and the Induction Compliance Checklist (ICC)

The results showed there was no significant difference in the mean state anxiety scores between the PPIA and control groups at T0 (33.4 \pm 13.6 vs $37.9 \pm 17.4 ; \mathrm{P}=0.162)$ and T1 (41.01 \pm 18.5 vs $44.2 \pm 17.4 ; \mathrm{P}=0.412)$. Significant differences were detected at $\mathrm{T} 2$ 
( $35.5 \pm 16.6$ vs $59.8 \pm 22 ; \mathrm{P}<0.001$. There was no difference in the number of anxious (mYPAS $>40$ ) patients in the PPIA and control groups at T0 (14 vs $18 ; \mathrm{P}=0.52)$ and $\mathrm{T} 1$ (27 vs 33; $\mathrm{P}=0.29$ ). The PPIA group showed lower scores when compared to the control group (18 vs 40; $\mathrm{P}<0.001)$. ICC scores revealed scores that were significantly different in the PPIA and control groups ( $66.6 \%$ vs $6.3 \%$; $\mathrm{P}<0.01)$. The STAI scores of parents did not differ in TO, T1, and T2. Parental satisfaction was higher in the PPIA group than the control group ( $7.6 \pm 7.0$ vs $5.8 \pm 6.1 ; \mathrm{P}<0.01)$.In conclusion, PPIA may reduce preoperative state anxiety in children and improve quality of induction of anesthesia based on ICC scores and greater parental satisfaction, although it did not impact parental state anxiety in this study (Sadeghi et al., 2016).

Sun, Qi, Dong, An, and Yuan (2007) (Appendix A-6) examined the effect of parental presence on perioperative anxiety of Chinese children aged four to six years old and their parents. One-hundred seventy-two children who suffered facial trauma and underwent facial debridement and soft tissue reconstruction with local anesthesia were recruited. Children were divided into two groups: the research group and the control group. Eighty-eight children and their parents were placed in the research group where a parent was allowed in the operating room to use conventional methods to relax the child. The control group consisted of 84 children and their parents; parents were not allowed to accompany the child in the operating room in this group. The visual analogue scale (VAS) for anxiety was adopted to measure the preoperative anxiety level of children and their parents.

Results showed preoperative and postoperative anxiety in children in the research group were statistically lower than the control group. The average preoperative anxiety in 
the research group $(67.13 \pm 11.320)$ was lower than the control group $(76.33 \pm 14.227)(\mathrm{p}<$ 0.05). The postoperative anxiety of the research group was different than the control group. The average anxiety of the research group $(56.96 \pm 11.35)$ was lower than the control group $(69.03 \pm 7.14)(\mathrm{p}<0.05)$. There was not significant statistical difference in the preoperative anxiety of both children and their parents between the two groups (Sun et al., 2017).

In conclusion, the use of parental presence did not always produce a decrease in childrens' anxiety in the operating room. Children may benefit from conventional methods of psychological interventions such as telling a story or distraction. These interventions are cost effective and may reduce the perioperative anxiety of children and their parents along with parental presence.

\section{Cross Study Analysis}

Appendix $\mathrm{C}$ provides a summary of key findings, recommendations, and limitations derived from each study. A study conducted by Chundamala et al. (2008) examined the effect of parental presence on both parents' and childrens' anxiety.

Fourteen studies were included in the study. Ten studies evaluated parents' anxiety; most of these studies did not find parental presence to be more effective than no parental presence. Six studies found no difference between parental presence and no parental presence. One study showed parental presence fared better than no parental presence, and the remaining studies showed mixed results (Chundamala et al., 2008). Eleven of the studies examined childrens' anxiety and most did not find parental presence to be more effective than no parental presence. (Chundamala et al.). Five studies found no 
difference, two studies determined that parental presence did have better outcomes than no parental presence, and the remaining studies showed mixed results (Chundamala et al.). Two studies did show parental presence with an adjunct such as distraction or premedication had superior results (Chundamala et al.).

The methods were compared across each study included in this integrative review. Vagnoli et al. (2010) evaluated patients' anxiety with parental presence, distraction, and premedication. Various methods were used to entertain the child including magic tricks, puppets, and games (Vagnoli et al.). Parental presence during induction of anesthesia and clown interventions were more effective in reducing childrens' anxiety than PPIA or PPIA and oral midazolam (Vagnoli et al.). Rasti et al. (2014), Jahanpour et al. (2017), and Sadeghi et al. (2017) examined the effects of PPIA on preoperative anxiety while other studies examined anxiety at times other than induction of anesthesia. Results showed no statistically significant difference between changes in the childrens' anxiety total scores. Sun et al. (2017) examined the effects of parental presence. The results showed preoperative and postoperative anxiety in children in the research group was significantly lower than the control group. All the studies differed in many ways including the number of subjects, which anxiety scales were used for measurement, the amount of time spent with the patients, the outcomes, and if distraction or premedication was used amongst the studies.

There were variations in the ways each study measured anxiety, including use of questionnaires, staff observations, and parent reports. There were reports by authors related to difficulty evaluating anxiety: a parents' reports may be different and inaccurate due to having unrealistic perception of the effect of their presence on their child 
(Chundamala et al,.2008). All reported decreases in anxiety were measured by an anxiety scale, though the actual scale varied. The visual analog scale (VAS) is a reliable and valid tool used to measure subjective data and the State Trait Anxiety Scale is a self-reported instrument designed to assess anxiety using a likert scale. Vagnoli et al., (2010) measured anxiety using the m-YPAS to evaluate the childrens' behavior in the waiting room and at induction of anesthesia in the operating room. The parents' anxiety was assessed using the Spielberg State-Trait Anxiety Inventory (STAI) and cooperation with the anesthesiologist was assessed using the Induction Compliance Checklist (ICC). Parental satisfaction was assessed using the VAS by Jahanpour et al. (2017), Rasti et al. (2014), and Sadeghi et al. (2017).

Finally, a lack of research of the effects of parental presence on pediatric anxiety was reported by Chundamala et al. (2008), Jahanpour et al (2017), Sadeghi et al. (2017) Vagnoli et al. (2010). Many of the authors suggested the need to clarify the effects of parental presence on anxiety levels due to mixed results. Chundamala et al. (2008) suggested that further exploration into the relationship/interaction between the childrens' anxiety and impact on the effectiveness of parental presence is needed. More studies about this phenomenon are necessary to determine the most useful intervention to lessen childrens' anxiety during anesthesia.

Next, the summary and conclusions will be presented. 


\section{Summary and Conclusions}

The hospital setting is particularly anxiety-provoking to children due to the unfamiliar environment, procedures, and people. An integrative review was conducted to explore the impact of parental presence on pediatric patients' anxiety during the operative experience. The Cumulative Index to Nursing and Allied Health Literature (CINAHL) and PubMed databases were searched and a comprehensive literature review was conducted to examine the impact of parental presence on pediatric patients' anxiety during the operative experience. Anxiety was measured using scales such as the VAS, STAI, and M-YPAS. Many of the studies examined the use of distraction and premedication along with parental presence. Inclusion and exclusion criteria were developed, studies were reviewed for eligibility, and results were charted in the PRISMA flowchart. Peplau's Theory of Interpersonal Relationships was used as a framework to guide this project. The Integrative Review: Updated Methodology by Whittemore and Knafl was used to guide this integrative review while summarizing the literature to provide a more comprehensive understanding. Polit and Beck's guides to an overall critique of qualitative and quantitative research were used to critically evaluate each article. Cross study analyses were then conducted to examine for common themes.

Many of the studies showed mixed results related to parental presence and reduction of anxiety. Chundamala et al. (2008) examined 11 studies which analyzed childrens' anxiety; five of the studies did not find parental presence to be more effective than no parental presence. Vagnoli et al. (2010) reported PPIA and clown interventions were more effective in reducing childrens' anxiety than PPIA or oral midazolam and PPIA. Rasti et al. (2014) and Jahanpour et al. (2017) showed no significant difference 
between changes in the childrens' anxiety with or without parental presence. Sadeghi et al. (2017) found no significant decrease in anxiety with the mYPAS scale and STAI scores showed no differences in childrens' anxiety during induction of anesthesia. Lastly, Sun et al. (2017) showed preoperative and postoperative anxiety in children was significantly lower in the group that allowed the parents to accompany the child in the operating room.

There were limitations to this integrative review. Many of the studies had a small sample size and a few studies may have had bias due to parents filling out questionnaires. The time of surgery may have also influenced the results due to the duration of NPO status or the amount of people/staff present at induction.

Many parents choose to be present during the induction of anesthesia to ease the induction process for both the child and the anesthesia provider. Findings suggest that parental presence can ease anxiety and fears in children. Surgery can be very stressful and separation from patients can cause anxiety in children. The goal is to reduce anxiety for children with non- pharmacological measures and techniques. Parental presence during the induction of anesthesia is becoming a common practice.

In conclusion, the literature within the integrative review supported parental presence as one tool to be used in reduction anxiety in pediatric children requiring anesthesia, although it did not always yield a decrease in the childrens' anxiety. Providing children and their families with low cost interventions such as parental presence and the use of distraction can be beneficial. The use of parental presence should be further studied and practiced. 
Recommendations and implications for advanced nursing practice will be discussed in the next section. 


\section{Recommendations and Implications for Advanced Nursing Practice}

The purpose of this integrative review was to examine parental presence and its' effects on anxiety in a clinical setting. Comparing findings from the selected studies can be used to better understand and incorporate parental presence into daily anesthesia practice. Application of parental presence in the hospital setting can be beneficial and existing knowledge of simple interventions could lead to better treatment to reduce anxiety during anesthesia.

The goal of a Certified Registered Nurse Anesthetist (CRNA) is to provide each patient with safe care that decreases potential negative outcomes while incorporating upto-date research through evidence-based practice. Pediatric patients can experience anxiety during anesthesia due to unfamiliarity of the environment. The negative effects of anxiety include increases in vital signs as well as increased anesthetic requirements and delayed wound healing (Manjunatha et al., 2017). If anxiety is untreated, it may lead to detrimental postoperative outcomes. Certified Registered Nurse Anesthetists can play a role in minimizing anxiety and providing the patient and family with non-invasive techniques to alleviate adverse effects. Certified Registered Nurse Anesthetists are able to advocate for their patients and eliminate potential side effects with cost effective, noninvasive techniques. While it is not yet clear that parental presence is more effective than premedication or distractions such as video games and/or clown therapy, it may be beneficial as an adjuvant.

Although parental presence may not be beneficial to all pediatric patients, it is useful to do a thorough screening to evaluate which patients and/or families would potentially benefit. Individualized preoperative evaluations help determine which 
anesthesia goals are in the best interest of the child. Supporting and implementing parental presence requires collaboration between healthcare providers. Certified Registered Nurse Anesthetists work closely with anesthesiologists and operating room nurses; together they can assess anxiety levels and provide individualized care aimed at reducing anxiety. A thorough health history and input from previous anesthesia records may provide the anesthesia team with considerations and recommendations for the tailored case.

The establishment of protocols, such as PPIA and distraction techniques, could reduce anxiety and negative outcomes if used with proper training and continuing education. Nurse anesthetists are highly educated providers who have the ability to create guidelines and provide resources to ensure exceptional anesthesia care to pediatric patients and their families with minimal impact on the flow of a busy operating room. Staff should be educated on techniques to make for a smoother induction, less fearful environment, and a more positive experience during the surgery or procedure. Studies are needed on this topic to assess the value of parental presence and which adjuncts should be used for better outcomes and to relieve anxiety in the pediatric population. Parental presence has been demonstrated to improve satisfaction scores and decrease overall anxiety. Research on the use of parental presence in the clinical setting has the potential to improve patient outcomes, guide practice, and assist advanced practitioners in providing safe, high quality care. Further study is needed, including study of the impact of parental presence in diverse samples. 


\section{References}

Al-Yateem, N., Brenner, M., Shorrab, A. A., \& Docherty, C. (2016). Play distraction versus pharmacological treatment to reduce anxiety levels in children undergoing day surgery: a randomized controlled non-inferiority trial. Child: Care, Health And Development, 42 (4), 572-581. Doi: 10.1111/cch.12343.

American Academy of Pediatrics (n.d.). Understanding childhood fears and anxieties. Retrieved from https://www.aap.org/.

American Psychiatric Association (2013). Diagnostic and statistical manual of mental disorders (5 $5^{\text {th }}$ ed.). Arlington, VA: American Psychiatric Publishing; 2013.

Banchs, R.J., \& Lerman, J. (2014). Preoperative anxiety management, emergence delirium, and postoperative behavior. Anesthesiology Clinics, 32(1), 1-23. doi:10.1016/j.anclin.2013.10.011

Bevan, J.C., Johnston, C., Haig, M.J., Tousignant, G., Lucy, S., Kirnon, V., Assimes, I.K., \& Carranza, R., (1990). Preoperative parental anxiety predicts behavioral and emotional responses to induction of anesthesia in children. Canadian Journal of Anesthesia, 37, 177-182.

Brayfield, A. (2014, January). "Clonidine”. Martindale: The complete drug reference. London, UK: Pharmaceutical Press.

Brazelton, T. B. (2006). Touchpoints birth to 3: your childs emotional and behavioral Development ( $2^{\text {nd }}$ ed.). Cambridge, MA: Da Capo Lifelong Books.

Centers for Disease Control and Prevention. (2013). Morbidity and mortality weekly report: Mental health surveillance among children--United States, 2005-2011.

Retrieved from https://www.cdc.gov/mmwr/preview/mmwrhtml/su6202a1.htm

Charana, A., Tripsianis, G., Matziou, V., Vaos, G., Iatrou, C., \& Chloropoulou, P. (2018). 
Preoperative anxiety in Greek children and their parents when presenting for routine surgery. Anesthesiology Research and Practice, 2018(2), 1-6. doi: $10.1155 / 2018 / 5135203$

Chow, C. H., Nejati, N., Poole, K. L., Van Lieshout, R. J., Buckley, N., \& Schmidt, L.A. (2017). Children's shyness in a surgical setting. Journal of the Canadian Academy of Child and Adolescent Psychiatry, 26(3), 100-107.

Chundamala, J., Wright, J. G., \& Kemp, S. M. (2008). An evidence-based review of parental presence during anesthesia induction and parent/child anxiety.Canadian Journal of Anesthesia/Journal Canadien Danesthésie,56(1), 57-70. doi:10.1007/s12630-008-9008-3

Clarke, A. R. (2009). Remembering Hildegard E. Peplau. Perspectives in Psychiatric Care, 35(3), 4-4. doi: 10.1111/j.1744-6163.1999.tb00578.x

Clinchy, M., Schulkin, J., Zanette, L. Y., Sheriff, M. J., Mcgowan, P. O., \& Boonstra, R. (2011). The neurological ecology of fear: insights neuroscientists and ecologists have to offer one another. Frontiers in Behavioral Neuroscience, 4.doi:10.3389/fnbeh.2011.00021

Eckenhoff, J.E. (1958). Relationship of anesthesia to postoperative personality changes in children. American Journal Dis Child, 86, 587-591.

Edelston, H. (1943). Separation anxiety in young children; a study of hospital cases. Genetic Psychology Monographs, 28, 3-95.

Flood, P., Rathmell, J. P., \& Shafer, S. (2015). Stoelting's pharmacology \& physiology in anesthetic practice (5th ed.). Philadelphia, PA: Wolters Kluwer Health.

Fortier, M., Del Rosario, A., Martin, S., and Kain, Z. (2010). Perioperative anxiety in 
children. Pediatric Anesthesia, 20, 318-322.

Fortier, M. A., \& Kain, Z. N. (2015). Treating perioperative anxiety and pain in children: a tailored and innovative approach. Pediatric Anesthesia, 25(1), 27-35. doi: 10.1111/pan. 12546

Fortier, M., Martin, S., Chorney, J., Mayes, L., \& Kain, Z. (2011). Preoperative anxiety in adolescents undergoing surgery: a pilot study. Pediatric Anesthesia 21, 969973.

Fox, N., Shaonkoff, J. (2011). How persistent fear and anxiety can affect young childrens' learning, behavior and health. Early Childhood Matters (116): 8-14.

Gurgel, P., Tourinho, F., \& Monterio, A. (2014). Collective consultation of growth and development of the child the light of theory of Peplau. Esc. Anna Nery, 18 (3). $539-543$

Huether, S.E. \& McCance, K.L. (2017). Understanding pathophysiolog $\left(6^{\text {th }}\right.$ ed.). St. Louis, MO: Elsevier

Jahanpour, F., Rasti-Emad-Abadi, R., Naboureh, A., Nasiri, M., \& Motamed, N. (2017). The effects of preanesthetic parental presence on preoperative anxiety of children and their parents: A randomized clinical trial study in Iran. Iranian Journal of Nursing and Midwifery Research,22(1), 72. doi:10.4103/ijnmr.ijnmr_178_14

Kahveci, K., Orrnek, D., Doger, C., Aydin, G.B., Aksoy, M., Emre, C., Deveci, A., Bozkurt, M., Ozgun, G. (2014). The effect of anesthesia type on stress hormone response: Comparison of general versus epidural anesthesia. Nigerian Journal of Clinical Practice, 17(4), 523-527.

Kain, Z.N., Caldwell-Andrews, A.A., Krivutza, D.M., Weinberg, M.E., Wang, S.M., \& 
Gaal, D. (2004). Trends in the practice of parental presence during induction of anesthesia and the use of preoperative sedative premedication in the United States, 1995-2002: results of a follow-up national survey. Anesthesia and Analgesia, 99(3), 1252-1259. doi: 10.1213/01.ane.0000111183.38618.d8

Kain, Z. N., Caldwell-Andrews, A. A., Mayes, L. C., Weinberg, M. E., Wang, S. M., MacLaren, J. E., \& Blount, R. (2007). Family-centered preparation for surgery improves perioperative outcomes in children: A randomized controlled trial. Anesthesiology, 98, 65-74.

Kain, Z.N., Mayes, L.C., Caldwell-Andrews, A.A., Karas, D.E., \& McClain, B.C. (2006). Preoperative anxiety, postoperative pain, and behavioral recovery in young children undergoing surgery. Pediatrics, 118(2), 651-658.

Kain, Z.N., Mayes, L.C., O’Connor, T.Z., \& Cicchetti, D.V. (1996). Preoperative anxiety in children. Predictors and outcomes. Archives of Pediatric and Adolescent Medicine, 150(12), 1238-1245.

Kain, Z.N., Wang, S.M., Mayes, L.C., Caramico, L.A., \& Hofstadter, M.B. (1999). Distress during the induction of anesthesia and postoperative behavioral outcomes. Anesth Analg, 88(5), 1042-1047.

Kruger, P., \& Rosen, D. (2016). Parental presence at induction of anesthesia is feasible with minimal preparation and resources. Canadian Journal of Anesthesia,63(10), 1207-1208. doi: 10.1007/s12630-016-0707-x

Kumari, S., Agrawal, N., Usha, G., Talwar, V., \& Gupta, P. (2017). Comparison of oral clonidine, oral dexmedetomidine, and oral midazolam for premedication in pediatric patients undergoing elective surgery. Anesthesia Essays and 
Researches, 11, 185-191. doi:10.4103/0259 1162.194586

Kurdi, M., \& Muthukala, S. (2016). A comparison of the effect of two doses of oral melatonin with oral midazolam and placebo on pre-operative anxiety, cognition and psychomotor function in children: A randomized double-blind study. Indian Journal of Anaesthesia,60(10), 744. doi: 10.4103/0019-5049.191688

Lerwick, J. L. (2016). Minimizing pediatric healthcare-induced anxiety and trauma. World Journal of Clinical Pediatrics, 5(2), 143-150. doi.org/10.5409/wjcp.v5.i2.143

Manjunatha S M., Hazra, R., Das, A., Chakraborty, S., Bose, R., Garain, S., \& Purkait, D., (2017). Effect of pre-anesthetic anxiety and heart rate on propofol dose requirement for induction: A correlation study.Asian Journal of Medical Sciences, 8(2), 64. doi:10.3126/ajms.v8i2.15451

Matziou, V., Chrysostomou, A., Vlahioti, E., \& Perdikaris, P. (2013). Parental presence and distraction during painful childhood procedures.British Journal of Nursing, 22(8), 470-475. doi:10.12968/bjon.2013.22.8.470

McCann, M.E. \& Kain, Z.N. (2001). The management of preoperative anxiety in children: an update. Anesth Analog, 93(1), 98-105.

McEwen, M., \& Willis, E. (2014). Theoretical basis for nursing (4th ed.). Philadelphia, PA: Lippincott Williams \& Wilkins.

Merikangas K.R., He J.P., Burstein M., Swanson S.A., Avenevoli S., Cui L., Benjet C., Georgiades K., \& Swendsen J. (2010). Lifetime prevalence of mental disorders in U.S. adolescents: results from the National Comorbidity Survey Replication-- 
Adolescent Supplement (NCS-A). J Am Acad Child Adolesc Psychiatry, 49(10), 980-989.

Miller, S.A., Church, E.B., \& Poole, C. (2018). Ages and stages: How children manage their fears. Retrieved from https://www.scholastic.com/teachers/articles/teachingcontent/ages-stages-how-children-manage-their-fears/.

Moher D, Liberati A, Tetzlaff J, Altman DG, the PRISMA Group (2009). Preferred Reporting Items for Systematic Reviews and Meta-Analyses: The PRISMA Statement. PLoS Med 6(6): e1000097. doi: 10.1371/journal.pmed1000097

Nagelhout, J. J., \& Plaus, K. L. (2015). Nurse anesthesia. St. Louis, MO: Elsevier/Saunders.

Nystrom, M. (2007). A patient-oriented perspective in existential issues: a theoretical argument for applying Peplau's interpersonal relation model in healthcare science and practice. Scandinavian Journal of Caring Sciences, 21(2), 282-288.

Paolo, A., Carlo, L., Cinzia, D., Valter, P., Pierluigi, N., \& Liliana, S. (2015). Stress response to surgery, anesthetics role and impact on cognition. Journal of Anesthesia \& Clinical Research, 6, 539. doi:10.4172/2155-6148.1000539

Peplau, H. E. (1997). Peplau's theory of interpersonal relations. Nursing Science Quarterly, 10(4), 162-167. doi: 10.1177/089431849701000407

Polit, D. F., \& Beck, C. T. (2017). Resource manual for nursing research: generating and assessing evidence for nursing practice. Philadelphia: Wolters Kluwer.

Purper-Ouakil, D. \& Franc, N. (2010). Separation anxiety in children. La Revue du Praticien, 60(6), 783-787.

Rasti, R., Jahanpour, F., \&Motamed, N. (2014). The effect of parental presence on 
anxiety during anesthesia induction in children 2 to 11 years of age undergoing surgery. Journal of Jahrom University of Medical Sciences, 12(1), 9-17. doi:10.29252/jmj.12.1.9

Sadeghi, A., Khaleghnejad Tabari, A., Mahdavi, A., Salarian, S., \& Sajjad Razavi, S. (2017). Impact of parental presence during induction of anesthesia on anxiety level among pediatric patients and their parents: A randomized clinical trial. Neuropsychiatric Disease and Treatment, 12, 3237-3241. doi:10.2147/NDT.S119208

Schulman, J.L., Foley, J.M., Vernon, D.T., \& Allan, D. (1967). A study of the effect of the mother's presence during anesthesia induction. Pediatrics, 39(1), 111-114. Scully, S.M. (2012). Parental presence during pediatric anesthesia induction. AORN Journal, 96(1), 26-33. doi:10.1016/j.aorn.2011.07.020

Seiden, S.C., Mcmullan, S., Sequera-Ramos, L., Oliveira, G.S., Roth, A., Rosenblatt, A., Jesdale, B.M., \& Suresh, S. (2014). Tablet-based interactive distraction (TBID) vs. oral midazolam to minimize perioperative anxiety in pediatric patients: A noninferiority randomized trial. Pediatric Anesthesia, 24(12), 1217-1223. doi:10.1111/pan.12475

Stone, L.L., Otten, R., Soenens, B., Engels, R.E., and Janssens, J.M. (2015). Relations between parental and child separation anxiety: The role of dependency-oriented psychological control. Journal of Child and Family Studies, 24(11), 3192-3199. doi:10.1007/s10826-015-0122-x

Sun, Y., Qi, S., Dong, X., An, J., \& Yuan, H. (2017). The effect of parental presence to perioperative anxiety of Chinese children and their parents. Biomedical 
Research,28(17), 7519-7522.

Vagnoli, L., Caprilli, S., \& Messeri, A. (2010). Parental presence, clowns or sedative premedication to treat preoperative anxiety in children: what could be the most promising option. Pediatric Anesthesia, 20, 937-943.

Watson, A.T., \& Visram, A. (2003). Children's preoperative anxiety and postoperative behavior. Paediatric Anaesthesia, 13, 188-204.`11

Weinberger, D.A., Schwartz, G.E., \& Davidson, R.J. (1979). Low-anxious, highanxious, and repressive coping styles: Psychometric patterns and behavioral and physiological responses to stress. Journal of Abnormal Psychology, 88(4), 369380.

Weiss, A.J. \& Elixhauser, A. (2014, October). Overview of hospital stays in the United States, 2012 (HCUP Statistical Brief No. 180). Retrieved from http://hcupus.ahrq.gov/reports/statbriefs/sb180-Hospitalizations-United -States-2012.pdf

Wittemore, R., \& Knafl, K. (2005). The integrative review: updated methodology. Journal of Advanced Nursing, 52(5), 546-553.

Wollin, S.R., Plummer, J.L., Owen, H., Hawkins, R.M., \& Materazzo, F. (2003). Predictors of preoperative anxiety in children. Anaesth Intensive Care, 31(1), 6974.

Wright, K.D., Stewart, S.H., Finley, G.A., \& Buffett-Jerrott, S.E. (2007). Prevention and intervention strategies to alleviate preoperative anxiety in children: a critical review. BehavModif, 31(1), 52-79. 


\section{Appendix A-1}

Chundamala, J., Wright, J. G., \& Kemp, S. M. (2008). An evidence-based review of

parental presence during anesthesia induction and parent/child anxiety. Canadian

Journal of Anesthesia/Journal Canadien Danesthésie,56(1), 57-70.

doi:10.1007/s12630-008-9008-3

\begin{tabular}{|c|c|}
\hline Critiquing Questions & Critique Responses \\
\hline $\begin{array}{l}\text { 1. Is the review thorough-does it } \\
\text { include all major studies on the } \\
\text { topic? Does it include recent } \\
\text { research (studies published within } \\
\text { previous 2-3 years)? Are studies } \\
\text { from other related disciplines } \\
\text { included, if appropriate? }\end{array}$ & $\begin{array}{l}\text { The researchers did a thorough literature } \\
\text { review which included all major studies on the } \\
\text { topic. The review included recent research as } \\
\text { well studies dated back as early as } 1988 \text {. No } \\
\text { studies from other related disciplines were } \\
\text { included in this review. }\end{array}$ \\
\hline $\begin{array}{l}\text { 2. Does the review rely mainly on } \\
\text { primary source research articles? } \\
\text { Are the articles from peer-reviewed } \\
\text { journals? }\end{array}$ & $\begin{array}{l}\text { The literature review relied mainly on primary } \\
\text { sources that were related to the research } \\
\text { articles. The articles included in this review } \\
\text { were from peer reviewed journals. }\end{array}$ \\
\hline $\begin{array}{l}\text { 3. Is the review merely a summary of } \\
\text { existing work, or does it critically } \\
\text { appraise and compare key studies? } \\
\text { Does the review identify important } \\
\text { gaps in the literature? }\end{array}$ & $\begin{array}{l}\text { The review critically appraised and compared } \\
\text { key studies. It did identify important gaps in } \\
\text { the literature. }\end{array}$ \\
\hline $\begin{array}{l}\text { Is the review well organized? Is the } \\
\text { development of ideas clear? }\end{array}$ & $\begin{array}{l}\text { The review was well organized and the } \\
\text { development of ideas was clearly written } \\
\text { throughout. }\end{array}$ \\
\hline $\begin{array}{l}\text { 5. Does the review use appropriate } \\
\text { language, suggesting the } \\
\text { tentativeness of prior findings? Is } \\
\text { the review objective? Does the } \\
\text { author paraphrase, or is there an } \\
\text { overreliance on quotes from original } \\
\text { sources? }\end{array}$ & $\begin{array}{l}\text { The literature review consisted of appropriate } \\
\text { language and suggested tentativeness of prior } \\
\text { findings. The review was based on objective } \\
\text { findings. The authors do paraphrase throughout } \\
\text { but there is not overreliance on quotes from } \\
\text { original work. }\end{array}$ \\
\hline $\begin{array}{l}\text { 6. If the review is part of a research } \\
\text { report for a new study, does the } \\
\text { review support the need for the } \\
\text { study? }\end{array}$ & $\begin{array}{l}\text { The literature review was not part of a research } \\
\text { report for a new study but provides a strong } \\
\text { basis for the need for a new study. }\end{array}$ \\
\hline $\begin{array}{l}\text { 7. If it is a review designed to } \\
\text { summarize evidence for clinical } \\
\text { practice, does the review draw } \\
\text { reasonable conclusions about } \\
\text { practice implications? }\end{array}$ & $\begin{array}{l}\text { The researchers discussed the implications } \\
\text { of the study in clinical practice and } \\
\text { summarized the evidence. The review drew } \\
\text { reasonable conclusions about practice } \\
\text { implications. }\end{array}$ \\
\hline
\end{tabular}




\section{Appendix A-2}

Vagnoli, L., Caprilli, S., and Messeri, A. (2010). Parental presence, clowns or sedative premedication to treat preoperative anxiety in children: what could be the most promising option. Pediatric Anesthesia, 20, 937-943.

\begin{tabular}{|c|c|c|}
\hline $\begin{array}{l}\text { Aspect of the } \\
\text { Report }\end{array}$ & Critiquing Questions & $\begin{array}{l}\text { Detailed } \\
\text { Critiquing } \\
\text { Guidelines }\end{array}$ \\
\hline Title & $\begin{array}{l}\text { - Is the title a good one, succinctly } \\
\text { suggesting key variables and the } \\
\text { study population? }\end{array}$ & $\begin{array}{l}\text { The title clearly } \\
\text { identified the key } \\
\text { variables, the } \\
\text { intervention, and } \\
\text { the study } \\
\text { population. }\end{array}$ \\
\hline Abstract & $\begin{array}{l}\text { Did the abstract clearly and } \\
\text { concisely summarize the main } \\
\text { features of the report (problem, } \\
\text { methods, results, conclusions)? }\end{array}$ & $\begin{array}{l}\text { The abstract } \\
\text { clearly and } \\
\text { concisely outlined } \\
\text { all the components } \\
\text { of the study. }\end{array}$ \\
\hline $\begin{array}{l}\text { Introduction } \\
\text { Statement of the } \\
\text { problem }\end{array}$ & $\begin{array}{l}\text { - Was the problem stated } \\
\text { unambiguously, and was it easy to } \\
\text { identify? } \\
\text { - Is the problem statement build a } \\
\text { persuasive argument for the new } \\
\text { study? } \\
\text { - Was there a good match between } \\
\text { the research problem and the } \\
\text { methods used -that is, was a } \\
\text { quantitative approach appropriate? }\end{array}$ & $\begin{array}{l}\text { The problem was } \\
\text { clearly stated and } \\
\text { the researchers } \\
\text { built a persuasive } \\
\text { argument for the } \\
\text { need of a new } \\
\text { study. } \\
\text { They used a } \\
\text { quantitative } \\
\text { approach, which } \\
\text { was appropriate } \\
\text { for the study. }\end{array}$ \\
\hline $\begin{array}{l}\text { Hypotheses or } \\
\text { research questions }\end{array}$ & $\begin{array}{l}\text { Were research questions and/or } \\
\text { hypotheses explicitly stated? If not, } \\
\text { was their absence justified? } \\
\text { Were questions and hypotheses } \\
\text { appropriately worded, with clear } \\
\text { specification of key variables and } \\
\text { the study population? } \\
\text { - Were the questions/hypotheses } \\
\text { consistent with existing } \\
\text { knowledge? }\end{array}$ & $\begin{array}{l}\text { The aim of the } \\
\text { study was clearly } \\
\text { stated as well as } \\
\text { the hypothesis. The } \\
\text { hypothesis was } \\
\text { clearly worded and } \\
\text { included the study } \\
\text { population and the } \\
\text { key variables. } \\
\text { The hypothesis } \\
\text { was consistent } \\
\text { with existing } \\
\text { knowledge. }\end{array}$ \\
\hline
\end{tabular}




\begin{tabular}{|c|c|c|}
\hline Aspect of the Report & Critiquing Questions & $\begin{array}{l}\text { Detailed } \\
\text { Critiquing } \\
\text { Guidelines }\end{array}$ \\
\hline Literature review & $\begin{array}{l}\text { Was the literature review up-to- } \\
\text { date and based mainly on primary } \\
\text { sources? } \\
\text { - Did the review provide a state-of- } \\
\text { the-art synthesis of evidence on } \\
\text { the problem? } \\
\text { - Did the literature review provide } \\
\text { a strong basis for the new study? }\end{array}$ & $\begin{array}{l}\text { The literature } \\
\text { review was brief, } \\
\text { but provided a } \\
\text { good synthesis of } \\
\text { evidence on the } \\
\text { problem and } \\
\text { strong basis for a } \\
\text { new study. } \\
\text { The literature } \\
\text { review provided } \\
\text { up-to-date and } \\
\text { mainly primary } \\
\text { sources. }\end{array}$ \\
\hline $\begin{array}{l}\text { Conceptual/theoretical } \\
\text { framework }\end{array}$ & $\begin{array}{l}\text { Were key concepts adequately } \\
\text { defined conceptually? } \\
\text { - Was a conceptual/theoretical } \\
\text { framework articulated-and, if so, } \\
\text { was it appropriate? If not, is the } \\
\text { absence of a framework justified? } \\
\text { - Were the questions/hypotheses } \\
\text { consistent with the framework? }\end{array}$ & $\begin{array}{l}\text { There was no } \\
\text { theoretical } \\
\text { framework } \\
\text { articulated. } \\
\text { Concepts were } \\
\text { adequately and } \\
\text { thoroughly defined. }\end{array}$ \\
\hline $\begin{array}{l}\text { Method } \\
\text { Protection of human } \\
\text { rights }\end{array}$ & $\begin{array}{l}\text { - Were appropriate procedures } \\
\text { used to safe-guard the rights of } \\
\text { study participants? } \\
\text { - Was the study externally } \\
\text { reviewed by an IRB/ethics review } \\
\text { board? } \\
\text { - Was the study designed to } \\
\text { minimize risks and maximize } \\
\text { benefits to participants? }\end{array}$ & $\begin{array}{l}\text { Appropriate } \\
\text { procedures were } \\
\text { used to safeguard } \\
\text { rights of patients. } \\
\text { The study was } \\
\text { approved by } \\
\text { ethical committee } \\
\text { and informed } \\
\text { consent was } \\
\text { obtained from all } \\
\text { participants. }\end{array}$ \\
\hline Research design & $\begin{array}{l}\text { Was the most rigorous design } \\
\text { used, given the study purpose? } \\
\text { Were appropriate comparisons } \\
\text { made to enhance interpretability } \\
\text { of the findings? } \\
\text { - Was the number of data collection } \\
\text { points appropriate? } \\
\text { Did the design minimize biases } \\
\text { and threats to the internal, } \\
\text { construct, and external validity of } \\
\text { the study (e.g., was blinding used, } \\
\text { was attrition minimized)? }\end{array}$ & $\begin{array}{l}\text { The study design } \\
\text { was a randomized } \\
\text { prospective study. } \\
\text { The design used } \\
\text { was consistent } \\
\text { with study goals } \\
\text { and purpose. } \\
\text { External validity } \\
\text { was limited } \\
\text { because it was a } \\
\text { single hospital } \\
\text { study. }\end{array}$ \\
\hline
\end{tabular}




\begin{tabular}{|c|c|c|}
\hline Aspect of the Report & Critiquing Questions & $\begin{array}{c}\text { Detailed Critiquing } \\
\text { Guidelines }\end{array}$ \\
\hline $\begin{array}{l}\text { Population and } \\
\text { sample }\end{array}$ & $\begin{array}{l}\text { Was the population identified? } \\
\text { Was the sample described in } \\
\text { sufficient detail? } \\
\text { Was the best possible sampling } \\
\text { design used to enhance the } \\
\text { sample's representativeness? } \\
\text { Were sampling biases minimized? } \\
\text { Was the sample size based on a } \\
\text { power analysis? }\end{array}$ & $\begin{array}{l}\text { The population was } \\
\text { identified. It } \\
\text { consisted of } \\
\text { children aged five to } \\
\text { twelve, scheduled to } \\
\text { undergo minor } \\
\text { surgery in Florence } \\
\text { or in the close } \\
\text { surroundings of the } \\
\text { city. }\end{array}$ \\
\hline $\begin{array}{l}\text { Data collection and } \\
\text { measurement }\end{array}$ & $\begin{array}{l}\text { Were the operational and } \\
\text { conceptual definitions congruent? } \\
\text { Were key variables measured } \\
\text { using an appropriate method } \\
\text { (e.g., interviews, observations, } \\
\text { and so on)? } \\
\text { - Were specific instruments } \\
\text { adequately described and were } \\
\text { they good choices, given the study } \\
\text { population and the variables } \\
\text { being studied? } \\
\text { Did the report provide evidence } \\
\text { that the data collection methods } \\
\text { yielded data that were reliable, } \\
\text { valid and responsive? }\end{array}$ & $\begin{array}{l}\text { The authors } \\
\text { performed the study } \\
\text { how they } \\
\text { conceptualized it. } \\
\text { Children were } \\
\text { assigned to one of } \\
\text { the three groups by } \\
\text { using compute- } \\
\text { generated list } \\
\text { random assignment. } \\
\text { The Modified Yale } \\
\text { Preoperative } \\
\text { Anxiety Scale (m- } \\
\text { YPAS) and the State- } \\
\text { Trait Anxiety } \\
\text { Inventory were } \\
\text { used for } \\
\text { measurement tools } \\
\text { These methods } \\
\text { were appropriate } \\
\text { for this research } \\
\text { design. }\end{array}$ \\
\hline Procedures & $\begin{array}{l}\text { If there was an intervention, was } \\
\text { it adequately described, and was } \\
\text { it rigorously developed and } \\
\text { implemented? Did most } \\
\text { participants allocated to the } \\
\text { intervention group actually } \\
\text { receive it? Was there evidence of } \\
\text { intervention fidelity? } \\
\text { - Were data collected in a manner } \\
\text { that minimized bias? Were the } \\
\text { staff who collected data } \\
\text { appropriately trained? }\end{array}$ & $\begin{array}{l}\text { The intervention } \\
\text { was described } \\
\text { adequately. } \\
\text { All interventions } \\
\text { were administered } \\
\text { as intended. } \\
\text { Date were collected } \\
\text { in a manor with } \\
\text { minimal bias. The } \\
\text { managing } \\
\text { anesthesiologist, the } \\
\text { parents, and the } \\
\text { other observers } \\
\text { were kept blinded } \\
\text { to the purpose of } \\
\text { the study and the }\end{array}$ \\
\hline
\end{tabular}




\begin{tabular}{|c|c|c|}
\hline Aspect of the Report & Critiquing Questions & $\begin{array}{c}\text { Detailed Critiquing } \\
\text { Guidelines }\end{array}$ \\
\hline Cont'd & & $\begin{array}{l}\text { groups involved, but } \\
\text { it was impossible to } \\
\text { be blind entirely to } \\
\text { assignment in the } \\
\text { control group due to } \\
\text { the parents of the } \\
\text { premedication } \\
\text { group were } \\
\text { informed their child } \\
\text { was receiving } \\
\text { medication. }\end{array}$ \\
\hline Data Analysis & $\begin{array}{l}\text { Were analyses undertaken to } \\
\text { address each research question } \\
\text { or test each hypothesis? } \\
\text { Were appropriate statistical } \\
\text { methods used, given the level of } \\
\text { measurement of the variables, } \\
\text { number of groups being } \\
\text { compared, and assumptions of } \\
\text { the texts? } \\
\text { - Was a powerful analytic method } \\
\text { used? (e.g., did the analysis help } \\
\text { to control for confounding } \\
\text { variables)? } \\
\text { Were type I and Type II errors } \\
\text { avoided or minimized? } \\
\text { In intervention studies, was an } \\
\text { intention-to-treat analysis } \\
\text { performed? }\end{array}$ & $\begin{array}{l}\text { The data were } \\
\text { appropriately } \\
\text { analyzed to address } \\
\text { the research } \\
\text { question. } \\
\text { Appropriate } \\
\text { statistical methods } \\
\text { were used. } \\
\text { Descriptive } \\
\text { statistics provided } \\
\text { an overview of the } \\
\text { relationships } \\
\text { between child and } \\
\text { parent variables, as } \\
\text { well as anxiety } \\
\text { levels in child and } \\
\text { parent. Data were } \\
\text { presented as mean } \pm \\
\text { sD. Data of m-YPAS } \\
\text { was verified } \\
\text { through Cohen's } k \\
\text { calculation. } \\
\text { Differenced } \\
\text { between groups } \\
\text { were examined } \\
\text { using the Scheffé } \\
\text { test. }\end{array}$ \\
\hline $\begin{array}{l}\text { Data Analysis } \\
\text { (continued) }\end{array}$ & $\begin{array}{l}\text { - Were problems of missing values } \\
\text { evaluated and adequately } \\
\text { addressed? }\end{array}$ & \\
\hline
\end{tabular}




\begin{tabular}{|c|c|c|}
\hline Aspect of the Report & Critiquing Questions & $\begin{array}{c}\text { Detailed Critiquing } \\
\text { Guidelines }\end{array}$ \\
\hline Findings & $\begin{array}{l}\text { Was information about statistical } \\
\text { significance presented? Was } \\
\text { information about effect size and } \\
\text { precision of estimates } \\
\text { (confidence intervals) presented? } \\
\text { - Were the findings adequately } \\
\text { summarized, with good use of } \\
\text { tables and figures? } \\
\text { - Were findings reported in a } \\
\text { manner that facilitates a meta- } \\
\text { analysis, and with sufficient } \\
\text { information needed for EBP? }\end{array}$ & $\begin{array}{l}\text { The results showed } \\
\text { no significant } \\
\text { differences between } \\
\text { the parents } \\
\text { attending the } \\
\text { induction of } \\
\text { anesthesia. The } \\
\text { correlations } \\
\text { between the anxiety } \\
\text { level of the child and } \\
\text { that of the parents } \\
\text { and between the } \\
\text { anxiety of the } \\
\text { parents and } \\
\text { demographic } \\
\text { characteristics were } \\
\text { not significant. } \\
\text { There was a } \\
\text { significant } \\
\text { correlation between } \\
\text { state anxiety (STAI- } \\
\text { Y-1) and trait } \\
\text { anxiety (STAI Y-2) } \\
\text { (r=0.23; P }<0.05 \text { ). } \\
\text { PPIA and clown } \\
\text { interventions were } \\
\text { more effective in } \\
\text { reducing children's } \\
\text { anxiety than PPIA or } \\
\text { PPIA and oral } \\
\text { midazolam. } \\
\text { There was good use } \\
\text { of tables. }\end{array}$ \\
\hline $\begin{array}{l}\text { Discussion } \\
\text { Interpretation of the } \\
\text { findings }\end{array}$ & $\begin{array}{l}\text { Were all major findings } \\
\text { interpreted and discussed within } \\
\text { the context of prior research } \\
\text { and/or the study's conceptual } \\
\text { framework? } \\
\text { - Were casual inferences, if any, } \\
\text { justified? } \\
\text { - Was the issue of clinical } \\
\text { significance discussed? } \\
\text { - Were interpretations well- } \\
\text { founded and consistent with the } \\
\text { study's limitations? }\end{array}$ & $\begin{array}{l}\text { The findings were } \\
\text { discussed within } \\
\text { content of previous } \\
\text { research, and the } \\
\text { clinical significance } \\
\text { was discussed. The } \\
\text { study was limited } \\
\text { because it was a } \\
\text { single hospital } \\
\text { setting, and blinding } \\
\text { was not possible. } \\
\text { The study did not } \\
\text { attempt to } \\
\text { generalize. The } \\
\text { study stated that the }\end{array}$ \\
\hline
\end{tabular}




\begin{tabular}{|c|c|c|}
\hline Aspect of the Report & Critiquing Questions & $\begin{array}{c}\text { Detailed Critiquing } \\
\text { Guidelines }\end{array}$ \\
\hline Cont'd & $\begin{array}{l}\text { - Did the report address the issue } \\
\text { of the generalizability of the } \\
\text { findings? }\end{array}$ & $\begin{array}{l}\text { findings may } \\
\text { provide a basis for } \\
\text { future studies } \\
\text { regarding PPIA, } \\
\text { professional clown } \\
\text { doctors, or } \\
\text { premedication in } \\
\text { reducing the child's } \\
\text { anxiety. }\end{array}$ \\
\hline $\begin{array}{l}\text { Implications/ } \\
\text { recommendations }\end{array}$ & $\begin{array}{l}\text { Did the researchers discuss the } \\
\text { implications of the study for } \\
\text { clinical practice or further } \\
\text { research-and were those } \\
\text { implications reasonable and } \\
\text { complete? }\end{array}$ & $\begin{array}{l}\text { The researchers } \\
\text { discussed the } \\
\text { implications of the } \\
\text { study in clinical } \\
\text { practice. They } \\
\text { suggested } \\
\text { encouraging non- } \\
\text { pharmacological } \\
\text { methods such as } \\
\text { having the presence } \\
\text { of clown doctors for } \\
\text { managing the child's } \\
\text { anxiety during } \\
\text { anesthesia and } \\
\text { surgery. }\end{array}$ \\
\hline $\begin{array}{l}\text { General Issues } \\
\text { Presentation }\end{array}$ & $\begin{array}{l}\text { Was the report well-written, } \\
\text { organized, and sufficiently } \\
\text { detailed for critical analysis? } \\
\text { In intervention studies, was a } \\
\text { CONSORT flowchart provided to } \\
\text { show the flow of participants in } \\
\text { the study? } \\
\text { Was the report written in a } \\
\text { manner that makes the findings } \\
\text { accessible to practicing nurses? }\end{array}$ & $\begin{array}{l}\text { The report was } \\
\text { written and } \\
\text { organized well and } \\
\text { allowed for critical } \\
\text { analysis. } \\
\text { CONSORT flow chart } \\
\text { was not used. }\end{array}$ \\
\hline Researcher credibility & $\begin{array}{l}\text { Do the researchers' clinical, } \\
\text { substantive, or methodologic } \\
\text { qualifications and experience } \\
\text { enhance confidence in the } \\
\text { findings and their interpretation? }\end{array}$ & $\begin{array}{l}\text { The study was } \\
\text { published in a peer } \\
\text { reviewed academic } \\
\text { journal. Many of the } \\
\text { researchers have } \\
\text { advanced medical } \\
\text { degrees and are } \\
\text { affiliated with Anna } \\
\text { Meyer Children's } \\
\text { Hospital in Florence, } \\
\text { Italy. }\end{array}$ \\
\hline
\end{tabular}




\begin{tabular}{|l|c|l|}
\hline Aspect of the Report & \multicolumn{1}{c|}{ Critiquing Questions } & $\begin{array}{l}\text { Detailed Critiquing } \\
\text { Guidelines }\end{array}$ \\
\hline Summary assessment & $\begin{array}{l}\text { Despite any limitations, do the } \\
\text { study findings appear to be } \\
\text { valid-do you have confidence in } \\
\text { the truth value of the results? } \\
\text { Does the study contribute any } \\
\text { meaningful evidence that can be } \\
\text { used in nursing practice or that is } \\
\text { useful to the nursing discipline? }\end{array}$ & $\begin{array}{l}\text { The findings do } \\
\text { appear to valid } \\
\text { despite it's } \\
\text { limitations. }\end{array}$ \\
\hline
\end{tabular}

*Reprinted with permission from the editor of D. Polit and C. Beck (2017). Nursing Research. Generating and assessing evidence for nursing practice $\left(10^{\text {th }} \mathrm{ed}\right.$.). Wolters Kluwer 


\section{Appendix A-3}

Rasti, R., Jahanpour, F., \& Motamed, N. (2014). The effect of parental presence on anxiety during anesthesia induction in children 2 to 11 years of age undergoing surgery. Journal of Jahrom University of Medical Sciences, 12(1), 9-17. doi:10.29252/jmj.12.1.

\begin{tabular}{|c|c|c|}
\hline $\begin{array}{l}\text { Aspect of the } \\
\text { Report }\end{array}$ & Critiquing Questions & $\begin{array}{l}\text { Detailed } \\
\text { Critiquing } \\
\text { Guidelines }\end{array}$ \\
\hline Title & 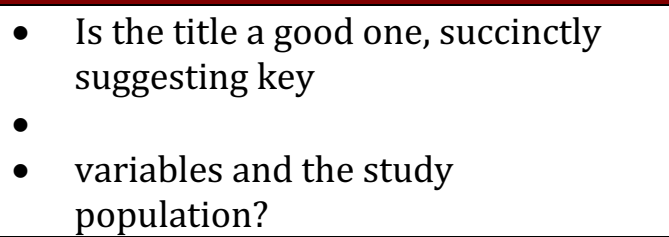 & $\begin{array}{l}\text { The title clearly } \\
\text { identified the } \\
\text { intervention and } \\
\text { the study } \\
\text { population. }\end{array}$ \\
\hline Abstract & $\begin{array}{l}\text { Did the abstract clearly and } \\
\text { concisely summarize the main } \\
\text { features of the report (problem, } \\
\text { methods, results, conclusions)? }\end{array}$ & $\begin{array}{l}\text { The abstract was } \\
\text { descriptive and } \\
\text { included an } \\
\text { introduction, } \\
\text { methods, results, } \\
\text { and conclusions. }\end{array}$ \\
\hline $\begin{array}{l}\text { Introduction } \\
\text { Statement of } \\
\text { the problem }\end{array}$ & $\begin{array}{l}\text { - Was the problem stated } \\
\text { unambiguously, and was it easy to } \\
\text { identify? } \\
\text { - Is the problem statement build a } \\
\text { persuasive argument for the new } \\
\text { study? } \\
\text { - Was there a good match between } \\
\text { the research problem and the } \\
\text { methods used -that is, was a } \\
\text { quantitative approach appropriate? }\end{array}$ & $\begin{array}{l}\text { The problem was } \\
\text { easy to identify } \\
\text { and suggested a } \\
\text { need for study. } \\
\text { The authors built } \\
\text { a persuasive } \\
\text { argument on } \\
\text { conducting a new } \\
\text { study to } \\
\text { investigate the } \\
\text { effect of parental } \\
\text { presence on } \\
\text { anxiety during } \\
\text { anesthesia } \\
\text { induction. }\end{array}$ \\
\hline $\begin{array}{l}\text { Hypotheses or } \\
\text { research } \\
\text { questions }\end{array}$ & $\begin{array}{l}\text { Were research questions and/or } \\
\text { hypotheses explicitly stated? If not, } \\
\text { was their absence justified? } \\
\text { Were questions and hypotheses } \\
\text { appropriately worded, with clear } \\
\text { specification of key variables and } \\
\text { the study population? }\end{array}$ & $\begin{array}{l}\text { The aim of the } \\
\text { study was clearly } \\
\text { stated in the } \\
\text { abstract, which } \\
\text { was to examine } \\
\text { the effect of } \\
\text { parental presence } \\
\text { on anxiety during }\end{array}$ \\
\hline
\end{tabular}




\begin{tabular}{|c|c|c|}
\hline Aspect of the Report & Critiquing Questions & $\begin{array}{c}\text { Detailed } \\
\text { Critiquing } \\
\text { Guidelines } \\
\end{array}$ \\
\hline Cont'd & $\begin{array}{l}\text { Were the } \\
\text { questions/hypotheses } \\
\text { consistent with existing } \\
\text { knowledge? }\end{array}$ & $\begin{array}{l}\text { anesthesia } \\
\text { induction in } \\
\text { children } 2 \text { to } 11 \\
\text { years of age } \\
\text { undergoing } \\
\text { surgery. } \\
\text { However, the } \\
\text { research } \\
\text { question was } \\
\text { not stated nor } \\
\text { was a } \\
\text { hypothesis. }\end{array}$ \\
\hline Literature review & $\begin{array}{l}\text { Was the literature review up- } \\
\text { to-date and based mainly on } \\
\text { primary sources? } \\
\text { - } \quad \text { Did the review provide a } \\
\text { state-of-the-art synthesis of } \\
\text { evidence on the problem? } \\
\text { - Did the literature review } \\
\text { provide a strong basis for the } \\
\text { new study? }\end{array}$ & $\begin{array}{l}\text { The study had a } \\
\text { brief literature } \\
\text { review that } \\
\text { discussed } \\
\text { previous } \\
\text { studies. } \\
\text { The literature } \\
\text { review was } \\
\text { thorough and } \\
\text { provided a } \\
\text { strong basis for } \\
\text { the new study. } \\
\text { The study did } \\
\text { not provide an } \\
\text { up-to-date } \\
\text { synthesis of } \\
\text { evidence on the } \\
\text { problem. }\end{array}$ \\
\hline $\begin{array}{l}\text { Conceptual/theoretical } \\
\text { framework }\end{array}$ & $\begin{array}{l}\text { - Were key concepts adequately } \\
\text { defined conceptually? } \\
\text { - Was a conceptual/theoretical } \\
\text { framework articulated-and, } \\
\text { if so, was it appropriate? If } \\
\text { not, is the absence of a } \\
\text { framework justified? } \\
\text { - Were the } \\
\text { questions/hypotheses } \\
\text { consistent with the } \\
\text { framework? }\end{array}$ & $\begin{array}{l}\text { No conceptual } \\
\text { framework was } \\
\text { articulated. }\end{array}$ \\
\hline
\end{tabular}




\begin{tabular}{|c|c|c|}
\hline Aspect of the Report & Critiquing Questions & $\begin{array}{c}\text { Detailed } \\
\text { Critiquing } \\
\text { Guidelines }\end{array}$ \\
\hline $\begin{array}{l}\text { Method } \\
\text { Protection of human } \\
\text { rights }\end{array}$ & $\begin{array}{l}\text { Were appropriate procedures } \\
\text { used to safe-guard the rights } \\
\text { of study participants? } \\
\text { - Was the study externally } \\
\text { reviewed by an IRB/ethics } \\
\text { review board? } \\
\text { - Was the study designed to } \\
\text { minimize risks and maximize } \\
\text { benefits to participants? }\end{array}$ & $\begin{array}{l}\text { Appropriate } \\
\text { procedures } \\
\text { were used to } \\
\text { safeguard the } \\
\text { rights of study } \\
\text { participants. } \\
\text { The study was } \\
\text { performed with } \\
\text { approval from } \\
\text { the ethics } \\
\text { committee and } \\
\text { informed } \\
\text { consent from the } \\
\text { parents of the } \\
\text { participating } \\
\text { children. }\end{array}$ \\
\hline Research design & $\begin{array}{l}\text { Was the most rigorous design } \\
\text { used, given the study } \\
\text { purpose? } \\
\text { - Were appropriate } \\
\text { comparisons made to enhance } \\
\text { interpretability of the } \\
\text { findings? } \\
\text { - Was the number of data } \\
\text { collection points appropriate? } \\
\text { Did the design minimize } \\
\text { biases and threats to the } \\
\text { internal, construct, and } \\
\text { external validity of the study } \\
\text { (e.g., was blinding used, was } \\
\text { attrition minimized)? }\end{array}$ & $\begin{array}{l}\text { A randomized } \\
\text { clinical trial } \\
\text { design was } \\
\text { used. } \\
\text { Participants } \\
\text { were randomly } \\
\text { divided into } \\
\text { control and case } \\
\text { groups. } \\
\text { The dependent } \\
\text { categorical } \\
\text { variable and } \\
\text { independent } \\
\text { variable were } \\
\text { anxiety and } \\
\text { parental } \\
\text { presence, } \\
\text { respectively. }\end{array}$ \\
\hline $\begin{array}{l}\text { Population and } \\
\text { sample }\end{array}$ & $\begin{array}{l}\text { Was the population } \\
\text { identified? Was the sample } \\
\text { described in sufficient detail? } \\
\text { Was the best possible } \\
\text { sampling design used to } \\
\text { enhance the sample's } \\
\text { representativeness? Were } \\
\text { sampling biases minimized? } \\
\text { Was the sample size } \\
\text { based on power } \\
\text { analysis? }\end{array}$ & $\begin{array}{l}\text { The study } \\
\text { population was } \\
\text { identified. } \\
\text { The study } \\
\text { consisted of } \\
\text { children aged 2- } \\
11 \text { years old } \\
\text { treated with } \\
\text { surgery. } \\
\text { Sample size was } \\
\text { based on power } \\
\text { analysis. }\end{array}$ \\
\hline
\end{tabular}




\begin{tabular}{|c|c|c|}
\hline Aspect of the Report & Critiquing Questions & $\begin{array}{l}\text { Detailed } \\
\text { Critiquing } \\
\text { Guidelines }\end{array}$ \\
\hline $\begin{array}{l}\text { Data collection and } \\
\text { measurement }\end{array}$ & $\begin{array}{l}\text { Were the operational and } \\
\text { conceptual definitions congruent? } \\
\text { Were key variables measured } \\
\text { using an appropriate method } \\
\text { (e.g., interviews, observations, } \\
\text { and so on)? } \\
\text { - Were specific instruments } \\
\text { adequately described and were } \\
\text { they good choices, given the study } \\
\text { population and the variables } \\
\text { being studied? } \\
\text { Did the report provide evidence } \\
\text { that the data collection methods } \\
\text { yielded data that were reliable, } \\
\text { valid and responsive? }\end{array}$ & $\begin{array}{l}\text { The data were } \\
\text { appropriately } \\
\text { analyzed and key } \\
\text { variables were } \\
\text { measured } \\
\text { appropriately by } \\
\text { m-YPAS scale. } \\
\text { The report } \\
\text { provided did show } \\
\text { evidence that the } \\
\text { data collection } \\
\text { methods yielded } \\
\text { data that was } \\
\text { reliable, valid, and } \\
\text { responsive. }\end{array}$ \\
\hline Procedures & $\begin{array}{l}\text { - If there was an intervention, was } \\
\text { it adequately described, and was } \\
\text { it rigorously developed and } \\
\text { implemented? Did most } \\
\text { participants allocated to the } \\
\text { intervention group actually } \\
\text { receive it? Was there evidence of } \\
\text { intervention fidelity? } \\
\text { - Were data collected in a manner } \\
\text { that minimized bias? Were the } \\
\text { staff who collected data } \\
\text { appropriately trained? }\end{array}$ & $\begin{array}{l}\text { The intervention } \\
\text { was adequately } \\
\text { described and } \\
\text { rigorously } \\
\text { developed and } \\
\text { implemented. A } \\
\text { total of } 60 \text { children } \\
\text { were included in } \\
\text { the study. } \\
\text { Data were } \\
\text { collected in a } \\
\text { manner that } \\
\text { minimized bias. } \\
\text { The researcher } \\
\text { provided } \\
\text { participants with } \\
\text { information on } \\
\text { methods of } \\
\text { research, } \\
\text { confidentiality of } \\
\text { the information, } \\
\text { and completion of } \\
\text { the questionnaire. }\end{array}$ \\
\hline Data Analysis & $\begin{array}{l}\text { Were analyses undertaken to } \\
\text { address each research question } \\
\text { or test each hypothesis? } \\
\text { Were appropriate statistical } \\
\text { methods used, given the level of } \\
\text { measurement of the variables, } \\
\text { number of groups being }\end{array}$ & $\begin{array}{l}\text { Appropriate } \\
\text { statistical methods } \\
\text { were used and } \\
\text { detailed analysis of } \\
\text { outcome variables } \\
\text { were conducted. } \\
\text { Data were analyzed } \\
\text { by descriptive }\end{array}$ \\
\hline
\end{tabular}




\begin{tabular}{|c|c|c|}
\hline Aspect of the Report & Critiquing Questions & $\begin{array}{c}\text { Detailed Critiquing } \\
\text { Guidelines }\end{array}$ \\
\hline $\begin{array}{l}\text { Data Analysis } \\
\text { (continued) }\end{array}$ & $\begin{array}{l}\text { - } \quad \text { compared, and assumptions of } \\
\text { the texts? } \\
\text { - Was a powerful analytic method } \\
\text { used? (e.g., did the analysis help } \\
\text { to control for confounding } \\
\text { variables)? } \\
\text { - Were type I and Type II errors } \\
\text { avoided or minimized? } \\
\text { - In intervention studies, was an } \\
\text { intention-to-treat analysis } \\
\text { performed? } \\
\text { Were problems of missing values } \\
\text { evaluated and adequately } \\
\text { addressed? }\end{array}$ & $\begin{array}{l}\text { statistics and chi- } \\
\text { square test, Fisher's } \\
\text { exact test, } t \text { and } \\
\text { paired-t tests by } \\
\text { using SPSS } 18 \\
\text { software. } \\
\text { No missing values } \\
\text { were identified. }\end{array}$ \\
\hline Findings & $\begin{array}{l}\text { - Was information about } \\
\text { statistical significance } \\
\text { presented? Was information } \\
\text { about effect size and precision of } \\
\text { estimates (confidence intervals) } \\
\text { presented? } \\
\text { - Were the findings adequately } \\
\text { summarized, with good use of } \\
\text { tables and figures? } \\
\text { Were findings reported in a } \\
\text { manner that facilitates a meta- } \\
\text { analysis, and with sufficient } \\
\text { information needed for EBP? }\end{array}$ & $\begin{array}{l}\text { Information about } \\
\text { statistical tests were } \\
\text { presented. The } \\
\text { findings were } \\
\text { accurately } \\
\text { summarized in } \\
\text { three charts. } \\
\text { The mean total } \\
\text { score of childrens' } \\
\text { anxiety in the } \\
\text { control group } \\
\text { (70.39 } \pm 20.93 \text { ) and } \\
\text { the experimental } \\
\text { group } \\
\text { (67.83 } \pm 16.78) \text { prior } \\
\text { to surgery (p>0.05) } \\
\text { were reported. No } \\
\text { significant } \\
\text { difference was } \\
\text { detected between } \\
\text { changes in the } \\
\text { childs' anxiety total } \\
\text { score in the control } \\
\text { group ( }-3 \pm 16.45 \text { ) } \\
\text { and experimental } \\
\text { group ( } 8.39 \pm 22.95 \text { ) } \\
\text { prior and after } \\
\text { surgery (p }>0.05 \text { ) }\end{array}$ \\
\hline
\end{tabular}




\begin{tabular}{|c|c|c|}
\hline Aspect of the Report & Critiquing Questions & $\begin{array}{c}\text { Detailed Critiquing } \\
\text { Guidelines }\end{array}$ \\
\hline $\begin{array}{l}\text { Discussion } \\
\text { Interpretation of the } \\
\text { findings }\end{array}$ & $\begin{array}{l}\text { Were all major findings } \\
\text { interpreted and discussed within } \\
\text { the context of prior research } \\
\text { and/or the study's conceptual } \\
\text { framework? } \\
\text { - Were casual inferences, if any, } \\
\text { justified? } \\
\text { - Was the issue of clinical } \\
\text { significance discussed? } \\
\text { Were interpretations well- } \\
\text { founded and consistent with the } \\
\text { study's limitations? } \\
\text { Did the report address the issue } \\
\text { of the generalizability of the } \\
\text { findings? }\end{array}$ & $\begin{array}{l}\text { The findings were } \\
\text { discussed within the } \\
\text { context of prior } \\
\text { research and clinical } \\
\text { significance was } \\
\text { discussed. } \\
\text { It appears that } \\
\text { parental presence } \\
\text { had no significant } \\
\text { effect on childrens' } \\
\text { anxiety while } \\
\text { undergoing surgery. } \\
\text { The authors } \\
\text { recommended that } \\
\text { in order to reduce } \\
\text { complications due } \\
\text { to surgical anxiety, } \\
\text { other interventions } \\
\text { should be explored. }\end{array}$ \\
\hline $\begin{array}{l}\text { Implications/ } \\
\text { recommendations }\end{array}$ & $\begin{array}{l}\text { Did the researchers discuss the } \\
\text { implications of the study for } \\
\text { clinical practice or further } \\
\text { research-and were those } \\
\text { implications reasonable and } \\
\text { complete? }\end{array}$ & $\begin{array}{l}\text { The researchers } \\
\text { identified the need } \\
\text { for future studies to } \\
\text { evaluate the effect } \\
\text { of parental presence } \\
\text { on anxiety during } \\
\text { anesthesia } \\
\text { induction in } \\
\text { children. }\end{array}$ \\
\hline $\begin{array}{l}\text { General Issues } \\
\text { Presentation }\end{array}$ & $\begin{array}{l}\text { Was the report well-written, } \\
\text { organized, and sufficiently } \\
\text { detailed for critical analysis? } \\
\text { In intervention studies, was a } \\
\text { CONSORT flowchart provided to } \\
\text { show the flow of participants in } \\
\text { the study? } \\
\text { Was the report written in a } \\
\text { manner that makes the findings } \\
\text { accessible to practicing nurses? }\end{array}$ & $\begin{array}{l}\text { The report was well } \\
\text { written, organized, } \\
\text { and sufficiently } \\
\text { detailed. } \\
\text { It was written in a } \\
\text { manner that made } \\
\text { the findings } \\
\text { accessible to } \\
\text { practicing nurses. }\end{array}$ \\
\hline Researcher credibility & $\begin{array}{l}\text { Do the researchers' clinical, } \\
\text { substantive, or methodologic } \\
\text { qualifications and experience } \\
\text { enhance confidence in the } \\
\text { findings and their } \\
\text { interpretation? }\end{array}$ & $\begin{array}{l}\text { The study was } \\
\text { published in an } \\
\text { academic journal. } \\
\text { There was } \\
\text { information on } \\
\text { qualifications within } \\
\text { the first and last } \\
\text { page of the article. }\end{array}$ \\
\hline
\end{tabular}




\begin{tabular}{|c|c|c|}
\hline Aspect of the Report & Critiquing Questions & $\begin{array}{c}\text { Detailed Critiquing } \\
\text { Guidelines }\end{array}$ \\
\hline Summary assessment & $\begin{array}{l}\text { Despite any limitations, do the } \\
\text { study findings appear to be } \\
\text { valid-do you have confidence } \\
\text { in the truth value of the results? } \\
\text { - Does the study contribute any } \\
\text { meaningful evidence that can be } \\
\text { used in nursing practice or that } \\
\text { is useful to the nursing } \\
\text { discipline? }\end{array}$ & $\begin{array}{l}\text { The study findings } \\
\text { appeared to be valid } \\
\text { and to afford truth } \\
\text { value to the results. } \\
\text { The study identified } \\
\text { a problem and } \\
\text { demonstrated that } \\
\text { effective } \\
\text { interventions } \\
\text { should be } \\
\text { conducted to } \\
\text { prevent childrens' } \\
\text { anxiety during } \\
\text { surgical operations. }\end{array}$ \\
\hline
\end{tabular}




\section{Appendix A-4}

Jahanpour, F., Rasti-Emad-Abadi, R., Naboureh, A., Nasiri, M., \& Motamed, N. (2017).

The effects of preanesthetic parental presence on preoperative anxiety of children and their parents: A randomized clinical trial study in Iran. Iranian Journal of

Nursing and Midwifery Research,22(1), 72. doi:10.4103/ijnmr.ijnmr_178_14

\begin{tabular}{|c|c|c|}
\hline Aspect of the Report & Critiquing Questions & $\begin{array}{l}\text { Detailed } \\
\text { Critiquing } \\
\text { Guidelines }\end{array}$ \\
\hline Title & $\begin{array}{l}\text { Is the title a good one, succinctly } \\
\text { suggesting key variables and the } \\
\text { study population? }\end{array}$ & $\begin{array}{l}\text { The title clearly } \\
\text { identified the key } \\
\text { variables, subject, } \\
\text { and time frame of } \\
\text { the study. }\end{array}$ \\
\hline Abstract & $\begin{array}{l}\text { Did the abstract clearly and } \\
\text { concisely summarize the main } \\
\text { features of the report (problem, } \\
\text { methods, results, conclusions)? }\end{array}$ & $\begin{array}{l}\text { The abstract was } \\
\text { descriptive and } \\
\text { included an } \\
\text { introduction, } \\
\text { methods, results, } \\
\text { and conclusions. }\end{array}$ \\
\hline $\begin{array}{l}\text { Introduction } \\
\text { Statement of the } \\
\text { problem }\end{array}$ & $\begin{array}{l}\text { - Was the problem stated } \\
\text { unambiguously, and was it easy } \\
\text { to identify? } \\
\text { - Is the problem statement build a } \\
\text { persuasive argument for the new } \\
\text { study? } \\
\text { - Was there a good match between } \\
\text { the research problem and the } \\
\text { methods used -that is, was a } \\
\text { quantitative approach } \\
\text { appropriate? }\end{array}$ & $\begin{array}{l}\text { The problem was } \\
\text { easily identified. } \\
\text { The authors built a } \\
\text { persuasive } \\
\text { argument for a new } \\
\text { study. The aim of } \\
\text { the study was to } \\
\text { investigate the } \\
\text { effects of parental } \\
\text { presence during } \\
\text { induction of } \\
\text { anesthesia PPIA on } \\
\text { preoperative } \\
\text { anxiety of children } \\
\text { as well as their } \\
\text { parents. There was } \\
\text { a good match } \\
\text { between the } \\
\text { research problem } \\
\text { and the methods } \\
\text { used in the study. }\end{array}$ \\
\hline
\end{tabular}




\begin{tabular}{|c|c|c|}
\hline Aspect of the Report & Critiquing Questions & $\begin{array}{l}\text { Detailed } \\
\text { Critiquing } \\
\text { Guidelines }\end{array}$ \\
\hline $\begin{array}{l}\text { Hypotheses or } \\
\text { research questions }\end{array}$ & $\begin{array}{l}\text { Were research questions and/or } \\
\text { hypotheses explicitly stated? If } \\
\text { not, was their absence justified? } \\
\text { Were questions and hypotheses } \\
\text { appropriately worded, with clear } \\
\text { specification of key variables and } \\
\text { the study population? } \\
\text { - Were the questions/hypotheses } \\
\text { consistent with existing } \\
\text { knowledge? }\end{array}$ & $\begin{array}{l}\text { The research } \\
\text { question was not } \\
\text { stated. However, } \\
\text { the aim of the } \\
\text { study was stated in } \\
\text { the abstract of the } \\
\text { article. } \\
\text { The hypothesis } \\
\text { was appropriately } \\
\text { worded and clearly } \\
\text { stated with } \\
\text { specification of key } \\
\text { variables and the } \\
\text { study population. } \\
\text { The hypothesis } \\
\text { was consistent } \\
\text { with existing } \\
\text { knowledge. }\end{array}$ \\
\hline Literature review & $\begin{array}{l}\text { Was the literature review up-to- } \\
\text { date and based mainly on } \\
\text { primary sources? } \\
\text { Did the review provide a state-of- } \\
\text { the-art synthesis of evidence on } \\
\text { the problem? } \\
\text { Did the literature review provide } \\
\text { a strong basis for the new study? }\end{array}$ & $\begin{array}{l}\text { The literature } \\
\text { review was up-to- } \\
\text { date and was based } \\
\text { mainly on primary } \\
\text { sources that } \\
\text { provided a strong } \\
\text { basis for a new } \\
\text { study. The } \\
\text { literature review } \\
\text { was thorough and } \\
\text { provided a good } \\
\text { synthesis of } \\
\text { evidence on the } \\
\text { problem }\end{array}$ \\
\hline $\begin{array}{l}\text { Conceptual/theoretical } \\
\text { framework }\end{array}$ & $\begin{array}{l}\text { - Were key concepts adequately } \\
\text { defined conceptually? } \\
\text { - Was a conceptual/theoretical } \\
\text { framework articulated-and, if } \\
\text { so, was it appropriate? If not, is } \\
\text { the absence of a framework } \\
\text { justified? } \\
\text { - Were the questions/hypotheses } \\
\text { consistent with the framework? }\end{array}$ & $\begin{array}{l}\text { There was no } \\
\text { theoretical } \\
\text { framework } \\
\text { identified. } \\
\text { Concepts were } \\
\text { defined and } \\
\text { thorough. }\end{array}$ \\
\hline
\end{tabular}




\begin{tabular}{|c|c|c|}
\hline Aspect of the Report & Critiquing Questions & $\begin{array}{l}\text { Detailed } \\
\text { Critiquing } \\
\text { Guidelines }\end{array}$ \\
\hline $\begin{array}{l}\text { Method } \\
\text { Protection of human } \\
\text { rights }\end{array}$ & $\begin{array}{l}\text { Were appropriate procedures } \\
\text { used to safe-guard the rights of } \\
\text { study participants? } \\
\text { - Was the study externally } \\
\text { reviewed by an IRB/ethics review } \\
\text { board? } \\
\text { - Was the study designed to } \\
\text { minimize risks and maximize } \\
\text { benefits to participants? }\end{array}$ & $\begin{array}{l}\text { No information } \\
\text { was given } \\
\text { regarding the } \\
\text { safeguarding the } \\
\text { rights of study } \\
\text { participants. The } \\
\text { authors did state } \\
\text { the study was } \\
\text { performed upon } \\
\text { approval by the } \\
\text { ethics board at } \\
\text { Busheher } \\
\text { University of } \\
\text { Medical sciences } \\
\text { and written } \\
\text { informed consents } \\
\text { were obtained } \\
\text { from all } \\
\text { participants. }\end{array}$ \\
\hline Research design & $\begin{array}{l}\text { Was the most rigorous design } \\
\text { used, given the study purpose? } \\
\text { - Were appropriate comparisons } \\
\text { made to enhance interpretability } \\
\text { of the findings? } \\
\text { - Was the number of data collection } \\
\text { points appropriate? } \\
\text { Did the design minimize biases } \\
\text { and threats to the internal, } \\
\text { construct, and external validity of } \\
\text { the study (e.g., was blinding used, } \\
\text { was attrition minimized)? }\end{array}$ & $\begin{array}{l}\text { This was a } \\
\text { randomized clinical } \\
\text { trial and was } \\
\text { registered on the } \\
\text { Iranian Registry of } \\
\text { Clinical Trials } \\
\text { (IRCT). } \\
\text { An appropriate } \\
\text { design for the } \\
\text { intent of the study } \\
\text { was employed. }\end{array}$ \\
\hline Population and sample & $\begin{array}{l}\text { Was the population identified? } \\
\text { Was the sample described in } \\
\text { sufficient detail? } \\
\text { - Was the best possible sampling } \\
\text { design used to enhance the } \\
\text { sample's representativeness? } \\
\text { Were sampling biases minimized? } \\
\text { - Was the sample size based on a } \\
\text { power analysis? }\end{array}$ & $\begin{array}{l}\text { The population } \\
\text { was identified as } \\
\text { children } 2 \text { to } 10 \\
\text { years of age, who } \\
\text { underwent minor- } \\
\text { medium elective } \\
\text { surgical } \\
\text { procedures with an } \\
\text { indication of } \\
\text { general anesthesia. } \\
\text { Sixty children } \\
\text { participated in this } \\
\text { study. } \\
\text { Sampling bias was } \\
\text { minimized. }\end{array}$ \\
\hline
\end{tabular}




\begin{tabular}{|c|c|c|}
\hline Aspect of the Report & Critiquing Questions & $\begin{array}{l}\text { Detailed } \\
\text { Critiquing } \\
\text { Guidelines }\end{array}$ \\
\hline $\begin{array}{l}\text { Data collection and } \\
\text { measurement }\end{array}$ & $\begin{array}{l}\text { - Were the operational and } \\
\text { conceptual definitions congruent? } \\
\text { Were key variables measured } \\
\text { using an appropriate method (e.g., } \\
\text { interviews, observations, and so } \\
\text { on)? } \\
\text { - Were specific instruments } \\
\text { adequately described and were } \\
\text { they good choices, given the study } \\
\text { population and the variables being } \\
\text { studied? } \\
\text { Did the report provide evidence } \\
\text { that the data collection methods } \\
\text { yielded data that were reliable, } \\
\text { valid and responsive? }\end{array}$ & $\begin{array}{l}\text { The authors } \\
\text { performed the } \\
\text { study how they } \\
\text { conceptualized it. } \\
\text { The method was } \\
\text { described } \\
\text { adequately. Key } \\
\text { variables were } \\
\text { measured using a } \\
\text { demographic } \\
\text { specification } \\
\text { questionnaire and } \\
\text { modified-Yale } \\
\text { preoperative } \\
\text { anxiety scale. } \\
\text { The report } \\
\text { provided evidence } \\
\text { that methods were } \\
\text { highly valid and } \\
\text { reliable. }\end{array}$ \\
\hline Procedures & $\begin{array}{l}\text { - If there was an intervention, was it } \\
\text { adequately described, and was it } \\
\text { rigorously developed and } \\
\text { implemented? Did most } \\
\text { participants allocated to the } \\
\text { intervention group actually } \\
\text { receive it? Was there evidence of } \\
\text { intervention fidelity? } \\
\text { - Were data collected in a manner } \\
\text { that minimized bias? Were the } \\
\text { staff who collected data } \\
\text { appropriately trained? }\end{array}$ & $\begin{array}{l}\text { Intervention was } \\
\text { adequately } \\
\text { described and } \\
\text { rigorously } \\
\text { developed and } \\
\text { implemented. } \\
\text { The children were } \\
\text { randomly divided } \\
\text { into case and } \\
\text { control groups. The } \\
\text { researcher } \\
\text { provided } \\
\text { participants with } \\
\text { necessary } \\
\text { information on the } \\
\text { method of the } \\
\text { research, } \\
\text { completion of the } \\
\text { questionnaire, and } \\
\text { confidentiality of } \\
\text { the information. } \\
\text { It was not noted if } \\
\text { the staff were } \\
\text { trained. }\end{array}$ \\
\hline
\end{tabular}




\begin{tabular}{|c|c|c|}
\hline Aspect of the Report & Critiquing Questions & $\begin{array}{l}\text { Detailed } \\
\text { Critiquing } \\
\text { Guidelines }\end{array}$ \\
\hline Data Analysis & $\begin{array}{l}\text { Were analyses undertaken to } \\
\text { address each research question or } \\
\text { test each hypothesis? } \\
\text { - Were appropriate statistical } \\
\text { methods used, given the level of } \\
\text { measurement of the variables, } \\
\text { number of groups being compared, } \\
\text { and assumptions of the texts? } \\
\text { - Was a powerful analytic method } \\
\text { used? (e.g., did the analysis help to } \\
\text { control for confounding } \\
\text { variables)? } \\
\text { Were type I and Type II errors } \\
\text { avoided or minimized? } \\
\text { In intervention studies, was an } \\
\text { intention-to-treat analysis } \\
\text { performed? } \\
\text { Were problems of missing values } \\
\text { evaluated and adequately } \\
\text { addressed? }\end{array}$ & $\begin{array}{l}\text { The data were } \\
\text { appropriately } \\
\text { analyzed to } \\
\text { address the } \\
\text { research question. } \\
\text { The statistical } \\
\text { method was } \\
\text { appropriate. } \\
\text { Results were } \\
\text { presented as } \\
\text { percentages, which } \\
\text { were appropriate } \\
\text { for the study. }\end{array}$ \\
\hline Findings & $\begin{array}{l}\text { Was information about statistical } \\
\text { significance presented? Was } \\
\text { information about effect size and } \\
\text { precision of estimates (confidence } \\
\text { intervals) presented? } \\
\text { - Were the findings adequately } \\
\text { summarized, with good use of } \\
\text { tables and figures? } \\
\text { Were findings reported in a } \\
\text { manner that facilitates a meta- } \\
\text { analysis, and with sufficient } \\
\text { information needed for EBP? }\end{array}$ & $\begin{array}{l}\text { The data were } \\
\text { presented in a } \\
\text { narrative with } \\
\text { percentages and } \\
\text { graphs in the form } \\
\text { of charts which } \\
\text { were summarized } \\
\text { within the study. } \\
\text { The results showed } \\
\text { the parental } \\
\text { presence had no } \\
\text { useful and } \\
\text { significant effect on } \\
\text { childrens' anxiety } \\
\text { undergoing } \\
\text { surgery. }\end{array}$ \\
\hline
\end{tabular}




\begin{tabular}{|c|c|c|}
\hline Aspect of the Report & Critiquing Questions & $\begin{array}{l}\text { Detailed } \\
\text { Critiquing } \\
\text { Guidelines }\end{array}$ \\
\hline $\begin{array}{l}\text { qDiscussion } \\
\text { Interpretation of the } \\
\text { findings }\end{array}$ & $\begin{array}{l}\text { M,ML Were all major findings } \\
\text { interpreted and discussed within } \\
\text { the context of prior research } \\
\text { and/or the study's conceptual } \\
\text { framework? } \\
\text { - Were casual inferences, if any, } \\
\text { justified? } \\
\text { - Was the issue of clinical } \\
\text { significance discussed? } \\
\text { - Were interpretations well-founded } \\
\text { and consistent with the study's } \\
\text { limitations? } \\
\text { Did the report address the issue of } \\
\text { the generalizability of the } \\
\text { findings? }\end{array}$ & $\begin{array}{l}\text { The findings were } \\
\text { discussed in the } \\
\text { context of the } \\
\text { research question. } \\
\text { Clinical significance } \\
\text { was discussed and } \\
\text { interpretations } \\
\text { were appropriate. } \\
\text { The interpretations } \\
\text { of the authors were } \\
\text { consistent with } \\
\text { limitations. } \\
\text { The study did not } \\
\text { attempt to } \\
\text { generalize results. }\end{array}$ \\
\hline $\begin{array}{l}\text { Implications/ } \\
\text { recommendations }\end{array}$ & $\begin{array}{l}\text { Did the researchers discuss the } \\
\text { implications of the study for } \\
\text { clinical practice or further } \\
\text { research-and were those } \\
\text { implications reasonable and } \\
\text { complete? }\end{array}$ & $\begin{array}{l}\text { The researchers } \\
\text { discussed the } \\
\text { implications of the } \\
\text { study for clinical } \\
\text { practice, as well as } \\
\text { further research. } \\
\text { Implications were } \\
\text { reasonable and } \\
\text { complete. }\end{array}$ \\
\hline $\begin{array}{l}\text { General Issues } \\
\text { Presentation }\end{array}$ & $\begin{array}{l}\text { Was the report well-written, } \\
\text { organized, and sufficiently detailed } \\
\text { for critical analysis? } \\
\text { In intervention studies, was a } \\
\text { CONSORT flowchart provided to } \\
\text { show the flow of participants in } \\
\text { the study? } \\
\text { Was the report written in a } \\
\text { manner that makes the findings } \\
\text { accessible to practicing nurses? }\end{array}$ & $\begin{array}{l}\text { The report was } \\
\text { well-written, } \\
\text { organized, and } \\
\text { detailed for critical } \\
\text { analysis. } \\
\text { CONSORT flow } \\
\text { chart was not used. }\end{array}$ \\
\hline Researcher credibility & $\begin{array}{l}\text { Do the researchers' clinical, } \\
\text { substantive, or methodologic } \\
\text { qualifications and experience } \\
\text { enhance confidence in the findings } \\
\text { and their interpretation? }\end{array}$ & $\begin{array}{l}\text { The study was } \\
\text { published in an } \\
\text { academic journal } \\
\text { and has been peer } \\
\text { reviewed. }\end{array}$ \\
\hline
\end{tabular}




\begin{tabular}{|c|c|c|}
\hline Aspect of the Report & Critiquing Questions & $\begin{array}{l}\text { Detailed } \\
\text { Critiquing } \\
\text { Guidelines }\end{array}$ \\
\hline Summary assessment & $\begin{array}{l}\text { Despite any limitations, do the } \\
\text { study findings appear to be valid- } \\
\text { do you have confidence in the } \\
\text { truth value of the results? } \\
\text { - Does the study contribute any } \\
\text { meaningful evidence that can be } \\
\text { used in nursing practice or that is } \\
\text { useful to the nursing discipline? }\end{array}$ & $\begin{array}{l}\text { The study findings } \\
\text { appear to be valid. }\end{array}$ \\
\hline
\end{tabular}

*Reprinted with permission from the editor of D. Polit and C. Beck (2017). Nursing Research. Generating and assessing evidence for nursing practice $\left(10^{\text {th }} \mathrm{ed}\right.$.). Wolters Kluwer. 


\section{Appendix A-5}

Sadeghi, A., Khaleghnejad Tabari, A., Mahdavi, A., Salarian, S., \& Sajjad Razavi, S. (2017). Impact of parental presence during induction of anesthesia on anxiety level among pediatric patients and their parents: A randomized clinical trial. Neuropsychiatric Disease and Treatment, 12, 3237-3241.

doi:10.2147/NDT.S119208

\begin{tabular}{|c|c|c|}
\hline Aspect of the Report & Critiquing Questions & $\begin{array}{l}\text { Detailed } \\
\text { Critiquing } \\
\text { Guidelines }\end{array}$ \\
\hline Title & $\begin{array}{l}\text { Is the title a good one, succinctly } \\
\text { suggesting key variables and the } \\
\text { study population? }\end{array}$ & $\begin{array}{l}\text { The title did clearly } \\
\text { indicate the key } \\
\text { variables, } \\
\text { intervention, and } \\
\text { the study } \\
\text { population. }\end{array}$ \\
\hline Abstract & $\begin{array}{l}\text { Did the abstract clearly and } \\
\text { concisely summarize the main } \\
\text { features of the report (problem, } \\
\text { methods, results, conclusions)? }\end{array}$ & $\begin{array}{l}\text { The abstract } \\
\text { clearly and } \\
\text { concisely outlined } \\
\text { all the components } \\
\text { of the study. }\end{array}$ \\
\hline $\begin{array}{l}\text { Introduction } \\
\text { Statement of the } \\
\text { problem }\end{array}$ & $\begin{array}{l}\text { - Was the problem stated } \\
\text { unambiguously, and was it easy } \\
\text { to identify? } \\
\text { - Is the problem statement build a } \\
\text { persuasive argument for the new } \\
\text { study? } \\
\text { - Was there a good match between } \\
\text { the research problem and the } \\
\text { methods used -that is, was a } \\
\text { quantitative approach } \\
\text { appropriate? }\end{array}$ & $\begin{array}{l}\text { The problem was } \\
\text { identified, clear, } \\
\text { and suggested a } \\
\text { need for further } \\
\text { study. } \\
\text { A randomized } \\
\text { controlled trial was } \\
\text { performed to } \\
\text { assess the impact } \\
\text { of parental } \\
\text { presence during } \\
\text { induction of } \\
\text { anesthesia (PPIA) } \\
\text { on preoperative } \\
\text { anxiety of pediatric } \\
\text { patients and their } \\
\text { parents. }\end{array}$ \\
\hline $\begin{array}{l}\text { Hypotheses or } \\
\text { research questions }\end{array}$ & $\begin{array}{l}\text { - Were research questions and/or } \\
\text { hypotheses explicitly stated? If } \\
\text { not, was their absence justified? } \\
\text { - Were questions and hypotheses } \\
\text { appropriately worded, with clear }\end{array}$ & $\begin{array}{l}\text { There was a } \\
\text { hypothesis that } \\
\text { was explicitly } \\
\text { stated. } \\
\text { The aim and } \\
\text { objective of the }\end{array}$ \\
\hline
\end{tabular}




\begin{tabular}{|c|c|c|}
\hline Aspect of the Report & Critiquing Questions & $\begin{array}{l}\text { Detailed } \\
\text { Critiquing } \\
\text { Guidelines }\end{array}$ \\
\hline Cont'd & $\begin{array}{l}\text { - } \quad \text { specification of key variables and } \\
\text { the study population? } \\
\text { - Were the questions/hypotheses } \\
\text { consistent with existing } \\
\text { knowledge? }\end{array}$ & $\begin{array}{l}\text { study was clearly } \\
\text { stated in the } \\
\text { abstract and } \\
\text { introduction. }\end{array}$ \\
\hline Literature review & $\begin{array}{l}\text { Was the literature review up-to- } \\
\text { date and based mainly on } \\
\text { primary sources? } \\
\text { Did the review provide a state-of- } \\
\text { the-art synthesis of evidence on } \\
\text { the problem? } \\
\text { Did the literature review provide } \\
\text { a strong basis for the new study? }\end{array}$ & $\begin{array}{l}\text { The literature } \\
\text { review was limited, } \\
\text { but it was based on } \\
\text { primary sources. } \\
\text { The literature } \\
\text { review provided a } \\
\text { strong basis for a } \\
\text { new study. }\end{array}$ \\
\hline $\begin{array}{l}\text { Conceptual/theoretical } \\
\text { framework }\end{array}$ & $\begin{array}{l}\text { - Were key concepts adequately } \\
\text { defined conceptually? } \\
\text { - Was a conceptual/theoretical } \\
\text { framework articulated-and, if } \\
\text { so, was it appropriate? If not, is } \\
\text { the absence of a framework } \\
\text { justified? } \\
\text { - Were the questions/hypotheses } \\
\text { consistent with the framework? }\end{array}$ & $\begin{array}{l}\text { There was no } \\
\text { theoretical } \\
\text { framework } \\
\text { articulated. } \\
\text { Concepts were } \\
\text { adequately defined. }\end{array}$ \\
\hline $\begin{array}{l}\text { Method } \\
\text { Protection of human } \\
\text { rights }\end{array}$ & $\begin{array}{l}\text { Were appropriate procedures } \\
\text { used to safe-guard the rights of } \\
\text { study participants? } \\
\text { - Was the study externally } \\
\text { reviewed by an IRB/ethics review } \\
\text { board? } \\
\text { - Was the study designed to } \\
\text { minimize risks and maximize } \\
\text { benefits to participants? }\end{array}$ & $\begin{array}{l}\text { Appropriate } \\
\text { procedures were } \\
\text { used to safeguard } \\
\text { rights of patients. } \\
\text { The study protocol } \\
\text { was approved by } \\
\text { the Research Ethics } \\
\text { Committee of } \\
\text { Shahid Beheshti } \\
\text { University of } \\
\text { Medical Sciences, } \\
\text { and all parents } \\
\text { provided informed } \\
\text { consent. }\end{array}$ \\
\hline Research design & $\begin{array}{l}\text { Was the most rigorous design } \\
\text { used, given the study purpose? } \\
\text { Were appropriate comparisons } \\
\text { made to enhance interpretability } \\
\text { of the findings? } \\
\text { - Was the number of data collection } \\
\text { points appropriate? } \\
\text { Did the design minimize biases } \\
\text { and threats to the internal, } \\
\text { construct, and external validity of }\end{array}$ & $\begin{array}{l}\text { The study design, a } \\
\text { randomized } \\
\text { control trial, was } \\
\text { consistent with the } \\
\text { study purpose. } \\
\text { Eligible patients } \\
\text { were randomly } \\
\text { assigned to one of } \\
\text { the two groups. }\end{array}$ \\
\hline
\end{tabular}




\begin{tabular}{|c|c|c|}
\hline Aspect of the Report & Critiquing Questions & $\begin{array}{l}\text { Detailed } \\
\text { Critiquing } \\
\text { Guidelines }\end{array}$ \\
\hline Cont'd & $\begin{array}{l}\text { - the study (e.g., was blinding used, } \\
\text { was attrition minimized)? }\end{array}$ & $\begin{array}{l}\text { External validity } \\
\text { was limited } \\
\text { because it was a } \\
\text { single center study. }\end{array}$ \\
\hline Population and sample & $\begin{array}{l}\text { Was the population identified? } \\
\text { Was the sample described in } \\
\text { sufficient detail? } \\
\text { - Was the best possible sampling } \\
\text { design used to enhance the } \\
\text { sample's representativeness? } \\
\text { Were sampling biases minimized? } \\
\text { Was the sample size based on a } \\
\text { power analysis? }\end{array}$ & $\begin{array}{l}\text { The population } \\
\text { was identified. It } \\
\text { consisted of } 96 \\
\text { pediatric patients } \\
\text { undergoing } \\
\text { elective minor } \\
\text { surgery randomly } \\
\text { divided into two } \\
\text { groups. } \\
\text { The sample size } \\
\text { was based on } \\
\text { power analysis. }\end{array}$ \\
\hline $\begin{array}{l}\text { Data collection and } \\
\text { measurement }\end{array}$ & $\begin{array}{l}\text { Were the operational and } \\
\text { conceptual definitions congruent? } \\
\text { Were key variables measured } \\
\text { using an appropriate method } \\
\text { (e.g., interviews, observations, } \\
\text { and so on)? } \\
\text { - Were specific instruments } \\
\text { adequately described and were } \\
\text { they good choices, given the study } \\
\text { population and the variables } \\
\text { being studied? } \\
\text { Did the report provide evidence } \\
\text { that the data collection methods } \\
\text { yielded data that were reliable, } \\
\text { valid and responsive? }\end{array}$ & $\begin{array}{l}\text { The authors } \\
\text { performed the } \\
\text { study as they } \\
\text { conceptualized it. } \\
\text { Key variables were } \\
\text { measured } \\
\text { appropriately. The } \\
\text { modified Yale } \\
\text { preoperative } \\
\text { Anxiety Scale } \\
\text { (mYPAS) was used } \\
\text { to measure } \\
\text { patients' anxiety; } \\
\text { parents were } \\
\text { measured using the } \\
\text { State and Trait } \\
\text { Anxiety Inventory } \\
\text { (STAI), the } \\
\text { Induction } \\
\text { Compliance } \\
\text { Checklist (ICC), and } \\
\text { parental } \\
\text { satisfaction was } \\
\text { measured by using } \\
\text { the Visual Analog } \\
\text { Scale (VAS). }\end{array}$ \\
\hline
\end{tabular}




\begin{tabular}{|c|c|c|}
\hline Aspect of the Report & Critiquing Questions & $\begin{array}{l}\text { Detailed } \\
\text { Critiquing } \\
\text { Guidelines }\end{array}$ \\
\hline Procedures & $\begin{array}{l}\text { - If there was an intervention, was } \\
\text { it adequately described, and was } \\
\text { it rigorously developed and } \\
\text { implemented? Did most } \\
\text { participants allocated to the } \\
\text { intervention group actually } \\
\text { receive it? Was there evidence of } \\
\text { intervention fidelity? } \\
\text { - Were data collected in a manner } \\
\text { that minimized bias? Were the } \\
\text { staff who collected data } \\
\text { appropriately trained? }\end{array}$ & $\begin{array}{l}\text { Intervention was } \\
\text { described in detail } \\
\text { and adequately in } \\
\text { the study. } \\
\text { All patients who } \\
\text { had inclusion } \\
\text { criteria were } \\
\text { selected. } \\
\text { Randomization } \\
\text { was used to } \\
\text { allocate the } \\
\text { selected } \\
\text { participants into } \\
\text { the control or PPIA } \\
\text { group. } \\
\text { Patients in the } \\
\text { control group } \\
\text { received } 0.5 \mathrm{mg} / \mathrm{kg} \\
\text { oral midazolam, } \\
\text { and patients in the } \\
\text { PPIA group } \\
\text { received 0.5 mg/kg } \\
\text { oral midazolam } \\
\text { and PPIA. } \\
\text { The data collection } \\
\text { method did } \\
\text { minimize bias. }\end{array}$ \\
\hline Data Analysis & $\begin{array}{l}\text { Were analyses undertaken to } \\
\text { address each research question } \\
\text { or test each hypothesis? } \\
\text { - Were appropriate statistical } \\
\text { methods used, given the level of } \\
\text { measurement of the variables, } \\
\text { number of groups being } \\
\text { compared, and assumptions of } \\
\text { the texts? } \\
\text { - Was a powerful analytic method } \\
\text { used? (e.g., did the analysis help } \\
\text { to control for confounding } \\
\text { variables)? } \\
\text { - Were type I and Type II errors } \\
\text { avoided or minimized? } \\
\text { In intervention studies, was an } \\
\text { intention-to-treat analysis } \\
\text { performed? }\end{array}$ & $\begin{array}{l}\text { The data were } \\
\text { analyzed to } \\
\text { address the } \\
\text { research question. } \\
\text { The statistical } \\
\text { method was } \\
\text { appropriate. } \\
\text { Mann-Whitney and } \\
\text { dependent sample } \\
\text {-test were used to } \\
\text { compare the means } \\
\text { of quantitative } \\
\text { variables between } \\
\text { the control and } \\
\text { PPIA groups. } \\
\text { Fisher's exact } t \text {-test } \\
\text { was used to } \\
\text { compare } \\
\text { quantitative }\end{array}$ \\
\hline
\end{tabular}




\begin{tabular}{|c|c|c|}
\hline Aspect of the Report & Critiquing Questions & $\begin{array}{c}\text { Detailed Critiquing } \\
\text { Guidelines }\end{array}$ \\
\hline $\begin{array}{l}\text { Data Analysis } \\
\text { (continued) }\end{array}$ & $\begin{array}{l}\text { - Were problems of missing values } \\
\text { evaluated and adequately } \\
\text { addressed? }\end{array}$ & $\begin{array}{l}\text { variables between } \\
\text { the two groups. }\end{array}$ \\
\hline Findings & $\begin{array}{l}\text { Was information about } \\
\text { statistical significance } \\
\text { presented? Was information } \\
\text { about effect size and precision of } \\
\text { estimates (confidence intervals) } \\
\text { presented? } \\
\text { - Were the findings adequately } \\
\text { summarized, with good use of } \\
\text { tables and figures? } \\
\text { Were findings reported in a } \\
\text { manner that facilitates a meta- } \\
\text { analysis, and with sufficient } \\
\text { information needed for EBP? }\end{array}$ & $\begin{array}{l}\text { Information } \\
\text { regarding statistical } \\
\text { significance was } \\
\text { presented. } \\
\text { The findings were } \\
\text { well summarized } \\
\text { including in five } \\
\text { tables. } \\
\text { The findings } \\
\text { included no } \\
\text { significant } \\
\text { difference in the } \\
\text { mean anxiety scores } \\
\text { (mYPAS). }\end{array}$ \\
\hline $\begin{array}{l}\text { Discussion } \\
\text { Interpretation of the } \\
\text { findings }\end{array}$ & $\begin{array}{l}\text { Were all major findings } \\
\text { interpreted and discussed within } \\
\text { the context of prior research } \\
\text { and/or the study's conceptual } \\
\text { framework? } \\
\text { - Were casual inferences, if any, } \\
\text { justified? } \\
\text { - Was the issue of clinical } \\
\text { significance discussed? } \\
\text { Were interpretations well- } \\
\text { founded and consistent with the } \\
\text { study's limitations? } \\
\text { Did the report address the issue } \\
\text { of the generalizability of the } \\
\text { findings? }\end{array}$ & $\begin{array}{l}\text { The findings were } \\
\text { discussed within the } \\
\text { context of the } \\
\text { research question. } \\
\text { Clinical significance } \\
\text { was discussed and } \\
\text { interpretations } \\
\text { were appropriate. } \\
\text { The authors did not } \\
\text { attempt to } \\
\text { generalize. The } \\
\text { authors stated that } \\
\text { PPIA in addition to } \\
\text { oral midazolam in } \\
\text { pediatric patients } \\
\text { can decrease } \\
\text { preoperative } \\
\text { anxiety which can } \\
\text { provide better } \\
\text { satisfaction in } \\
\text { parents and better } \\
\text { cooperation with } \\
\text { anesthesiologist at } \\
\text { induction of } \\
\text { anesthesia. }\end{array}$ \\
\hline
\end{tabular}




\begin{tabular}{|c|c|c|}
\hline Aspect of the Report & Critiquing Questions & $\begin{array}{c}\text { Detailed Critiquing } \\
\text { Guidelines }\end{array}$ \\
\hline $\begin{array}{l}\text { Implications/ } \\
\text { recommendations }\end{array}$ & $\begin{array}{l}\text { Did the researchers discuss the } \\
\text { implications of the study for } \\
\text { clinical practice or further } \\
\text { research-and were those } \\
\text { implications reasonable and } \\
\text { complete? }\end{array}$ & $\begin{array}{l}\text { The authors } \\
\text { identified the need } \\
\text { for future studies to } \\
\text { evaluate the effects } \\
\text { of parental presence } \\
\text { during the induction } \\
\text { of anesthesia on } \\
\text { anxiety levels } \\
\text { among pediatric } \\
\text { patients. }\end{array}$ \\
\hline $\begin{array}{l}\text { General Issues } \\
\text { Presentation }\end{array}$ & $\begin{array}{l}\text { Was the report well-written, } \\
\text { organized, and sufficiently } \\
\text { detailed for critical analysis? } \\
\text { In intervention studies, was a } \\
\text { CONSORT flowchart provided to } \\
\text { show the flow of participants in } \\
\text { the study? } \\
\text { Was the report written in a } \\
\text { manner that makes the findings } \\
\text { accessible to practicing nurses? }\end{array}$ & $\begin{array}{l}\text { The report was easy } \\
\text { to follow, well } \\
\text { organized and } \\
\text { detailed } \\
\text { CONSORT flow chart } \\
\text { was not used. }\end{array}$ \\
\hline Researcher credibility & $\begin{array}{l}\text { Do the researchers' clinical, } \\
\text { substantive, or methodologic } \\
\text { qualifications and experience } \\
\text { enhance confidence in the } \\
\text { findings and their } \\
\text { interpretation? }\end{array}$ & $\begin{array}{l}\text { The study was } \\
\text { published in a peer } \\
\text { reviewed academic } \\
\text { journal. } \\
\text { There was } \\
\text { information about } \\
\text { the authors' } \\
\text { qualifications and } \\
\text { experience on the } \\
\text { first page as well as } \\
\text { the last page. }\end{array}$ \\
\hline Summary assessment & $\begin{array}{l}\text { Despite any limitations, do the } \\
\text { study findings appear to be } \\
\text { valid-do you have confidence } \\
\text { in the truth value of the results? } \\
\text { - Does the study contribute any } \\
\text { meaningful evidence that can be } \\
\text { used in nursing practice or that } \\
\text { is useful to the nursing } \\
\text { discipline? }\end{array}$ & $\begin{array}{l}\text { The study findings } \\
\text { appear to be valid } \\
\text { and results } \\
\text { appeared to have } \\
\text { truth value. }\end{array}$ \\
\hline
\end{tabular}




\section{Appendix A-6}

Sun, Y., Qi, S., Dong, X., An, J., \& Yuan, H. (2017). The effect of parental presence to perioperative anxiety of Chinese children and their parents. Biomedical Research,28(17), 7519-7522.

\begin{tabular}{|c|c|c|}
\hline Aspect of the Report & Critiquing Questions & $\begin{array}{l}\text { Detailed } \\
\text { Critiquing } \\
\text { Guidelines }\end{array}$ \\
\hline Title & $\begin{array}{l}\text { Is the title a good one, succinctly } \\
\text { suggesting key variables and the } \\
\text { study population? }\end{array}$ & $\begin{array}{l}\text { The title clearly } \\
\text { identified the } \\
\text { intervention and } \\
\text { the study } \\
\text { population }\end{array}$ \\
\hline Abstract & $\begin{array}{l}\text { Did the abstract clearly and } \\
\text { concisely summarize the main } \\
\text { features of the report (problem, } \\
\text { methods, results, conclusions)? }\end{array}$ & $\begin{array}{l}\text { The abstract } \\
\text { clearly and } \\
\text { concisely } \\
\text { summarized the } \\
\text { components of the } \\
\text { study and included } \\
\text { the object, method, } \\
\text { result, and } \\
\text { conclusion. }\end{array}$ \\
\hline $\begin{array}{l}\text { Introduction } \\
\text { Statement of the } \\
\text { problem }\end{array}$ & $\begin{array}{l}\text { Was the problem stated } \\
\text { unambiguously, and was it easy } \\
\text { to identify? } \\
\text { - Is the problem statement build a } \\
\text { persuasive argument for the new } \\
\text { study? } \\
\text { Was there a good match between } \\
\text { the research problem and the } \\
\text { methods used -that is, was a } \\
\text { quantitative approach } \\
\text { appropriate? }\end{array}$ & $\begin{array}{l}\text { The problem was } \\
\text { easily identified, } \\
\text { clear, and suggests } \\
\text { a need for study. } \\
\text { Introduction } \\
\text { suggested benefits } \\
\text { of parental } \\
\text { presence and its' } \\
\text { anxiolytic effects } \\
\text { during induction of } \\
\text { anesthesia and } \\
\text { built a persuasive } \\
\text { argument. }\end{array}$ \\
\hline $\begin{array}{l}\text { Hypotheses or } \\
\text { research questions }\end{array}$ & $\begin{array}{l}\text { Were research questions and/or } \\
\text { hypotheses explicitly stated? If } \\
\text { not, was their absence justified? } \\
\text { Were questions and hypotheses } \\
\text { appropriately worded, with clear } \\
\text { specification of key variables and } \\
\text { the study population? }\end{array}$ & $\begin{array}{l}\text { No hypothesis was } \\
\text { presented or } \\
\text { explicitly stated. } \\
\text { The objective of the } \\
\text { study were clearly } \\
\text { identified and key } \\
\text { variables were } \\
\text { included. }\end{array}$ \\
\hline
\end{tabular}




\begin{tabular}{|c|c|c|}
\hline Aspect of the Report & Critiquing Questions & $\begin{array}{l}\text { Detailed } \\
\text { Critiquing } \\
\text { Guidelines }\end{array}$ \\
\hline & $\begin{array}{l}\text { - Were the questions/hypotheses } \\
\text { consistent with existing } \\
\text { knowledge? }\end{array}$ & $\begin{array}{l}\text { The research } \\
\text { problem was } \\
\text { consistent with } \\
\text { existing } \\
\text { knowledge. }\end{array}$ \\
\hline Literature review & $\begin{array}{l}\text { Was the literature review up-to- } \\
\text { date and based mainly on } \\
\text { primary sources? } \\
\text { Did the review provide a state-of- } \\
\text { the-art synthesis of evidence on } \\
\text { the problem? } \\
\text { - Did the literature review provide } \\
\text { a strong basis for the new study? }\end{array}$ & $\begin{array}{l}\text { The study had a } \\
\text { brief literature } \\
\text { review and mainly } \\
\text { used up-to-date } \\
\text { primary sources. } \\
\text { It provided a good } \\
\text { summary of the } \\
\text { current evidence } \\
\text { and a strong basis } \\
\text { for a new study. } \\
\end{array}$ \\
\hline $\begin{array}{l}\text { Conceptual/theoretical } \\
\text { framework }\end{array}$ & $\begin{array}{l}\text { Were key concepts adequately } \\
\text { defined conceptually? } \\
\text { - Was a conceptual/theoretical } \\
\text { framework articulated-and, if so, } \\
\text { was it appropriate? If not, is the } \\
\text { absence of a framework justified? } \\
\text { - Were the questions/hypotheses } \\
\text { consistent with the framework? }\end{array}$ & $\begin{array}{l}\text { No conceptual } \\
\text { framework was } \\
\text { articulated. }\end{array}$ \\
\hline $\begin{array}{l}\text { Method } \\
\text { Protection of human } \\
\text { rights }\end{array}$ & $\begin{array}{l}\text { Were appropriate procedures } \\
\text { used to safe-guard the rights of } \\
\text { study participants? } \\
\text { - Was the study externally } \\
\text { reviewed by an IRB/ethics review } \\
\text { board? } \\
\text { - Was the study designed to } \\
\text { minimize risks and maximize } \\
\text { benefits to participants? }\end{array}$ & $\begin{array}{l}\text { The study was } \\
\text { approved by } \\
\text { IRB/ethics board. } \\
\text { Informed consent } \\
\text { was obtained prior } \\
\text { to the study. }\end{array}$ \\
\hline Research design & $\begin{array}{l}\text { Was the most rigorous design } \\
\text { used, given the study purpose? } \\
\text { Were appropriate comparisons } \\
\text { made to enhance interpretability } \\
\text { of the findings? } \\
\text { - Was the number of data collection } \\
\text { points appropriate? } \\
\text { Did the design minimize biases } \\
\text { and threats to the internal, } \\
\text { construct, and external validity of } \\
\text { the study (e.g., was blinding used, } \\
\text { was attrition minimized)? }\end{array}$ & $\begin{array}{l}\text { The study design } \\
\text { was a Randomized } \\
\text { Control Trial } \\
\text { (RCT). Blinding } \\
\text { was not possible } \\
\text { because of the } \\
\text { nature of the } \\
\text { intervention. } \\
\text { External validity } \\
\text { was limited } \\
\text { because it was a } \\
\text { single center study. }\end{array}$ \\
\hline
\end{tabular}




\begin{tabular}{|c|c|c|}
\hline Aspect of the Report & Critiquing Questions & $\begin{array}{c}\text { Detailed Critiquing } \\
\text { Guidelines }\end{array}$ \\
\hline $\begin{array}{l}\text { Population and } \\
\text { sample }\end{array}$ & $\begin{array}{l}\text { Was the population identified? Was the } \\
\text { sample described in sufficient detail? } \\
\text { Was the best possible sampling design } \\
\text { used to enhance the sample's } \\
\text { representativeness? Were sampling } \\
\text { biases minimized? } \\
\text { Was the sample size based on a power } \\
\text { analysis? }\end{array}$ & $\begin{array}{l}\text { The population was } \\
\text { identified and } \\
\text { described in detail. } \\
\text { The study had } 172 \\
\text { Chinese } 4-6 \text { years old } \\
\text { children who suffered } \\
\text { facial trauma and } \\
\text { underwent facial } \\
\text { debridement and soft } \\
\text { tissue reconstruction. }\end{array}$ \\
\hline $\begin{array}{l}\text { Data collection and } \\
\text { measurement }\end{array}$ & $\begin{array}{l}\text { Were the operational and } \\
\text { conceptual definitions congruent? } \\
\text { Were key variables measured } \\
\text { using an appropriate method (e.g., } \\
\text { interviews, observations, and so } \\
\text { on)? } \\
\text { Were specific instruments } \\
\text { adequately described and were } \\
\text { they good choices, given the study } \\
\text { population and the variables being } \\
\text { studied? } \\
\text { Did the report provide evidence } \\
\text { that the data collection methods } \\
\text { yielded data that were reliable, } \\
\text { valid and responsive? }\end{array}$ & $\begin{array}{l}\text { The authors } \\
\text { performed the study } \\
\text { how they } \\
\text { conceptualized it. } \\
\text { The key variables } \\
\text { were adequately } \\
\text { described. } \\
\text { The outcome measure } \\
\text { was the Visual } \\
\text { Analogue Scale for } \\
\text { Anxiety (VAS-A), used } \\
\text { to quantify the } \\
\text { perioperative anxiety } \\
\text { of both children and } \\
\text { their parents. }\end{array}$ \\
\hline Procedures & $\begin{array}{l}\text { - If there was an intervention, was it } \\
\text { adequately described, and was it } \\
\text { rigorously developed and } \\
\text { implemented? Did most } \\
\text { participants allocated to the } \\
\text { intervention group actually } \\
\text { receive it? Was there evidence of } \\
\text { intervention fidelity? } \\
\text { Were data collected in a manner } \\
\text { that minimized bias? Were the } \\
\text { staff who collected data } \\
\text { appropriately trained? }\end{array}$ & $\begin{array}{l}\text { The intervention was } \\
\text { described adequately. } \\
\text { There were } 88 \mathrm{t} \\
\text { children and their } \\
\text { parents in the } \\
\text { research group and } \\
\text { the parents were able } \\
\text { to accompany the } \\
\text { child in the operating } \\
\text { room. Eighty-four } \\
\text { children and their } \\
\text { parents in the control } \\
\text { group were not } \\
\text { allowed in the } \\
\text { operating room. }\end{array}$ \\
\hline
\end{tabular}




\begin{tabular}{|c|c|c|}
\hline Aspect of the Report & Critiquing Questions & $\begin{array}{c}\text { Detailed Critiquing } \\
\text { Guidelines }\end{array}$ \\
\hline Data Analysis & $\begin{array}{l}\text { Were analyses undertaken to } \\
\text { address each research question or } \\
\text { test each hypothesis? } \\
\text { Were appropriate statistical } \\
\text { methods used, given the level of } \\
\text { measurement of the variables, } \\
\text { number of groups being compared, } \\
\text { and assumptions of the texts? } \\
\text { - Was a powerful analytic method } \\
\text { used? (e.g., did the analysis help to } \\
\text { control for confounding } \\
\text { variables)? } \\
\text { Were type I and Type II errors } \\
\text { avoided or minimized? } \\
\text { In intervention studies, was an } \\
\text { intention-to-treat analysis } \\
\text { performed? } \\
\text { Were problems of missing values } \\
\text { evaluated and adequately } \\
\text { addressed? }\end{array}$ & $\begin{array}{l}\text { The data were well } \\
\text { analyzed to address } \\
\text { the research question. } \\
\text { The statistical } \\
\text { method was } \\
\text { appropriate. } \\
\text { Both groups were } \\
\text { examined by SPSS } \\
13.0 \text { through table } \\
\text { analysis and } \\
\text { independent t test to } \\
\text { ensure veracity of } \\
\text { the study. } \\
\text { Preoperative and } \\
\text { postoperative anxiety } \\
\text { of both groups were } \\
\text { analyzed through } \\
\text { independent test to } \\
\text { determine whether } \\
\text { parental presence } \\
\text { will affect the } \\
\text { childrens' } \\
\text { perioperative anxiety. } \\
\text { Lastly, preoperative } \\
\text { and postoperative } \\
\text { anxiety of the parents } \\
\text { examined whether } \\
\text { parental presence } \\
\text { effected the parents' } \\
\text { perioperative anxiety. }\end{array}$ \\
\hline Findings & $\begin{array}{l}\text { Was information about statistical } \\
\text { significance presented? Was } \\
\text { information about effect size and } \\
\text { precision of estimates (confidence } \\
\text { intervals) presented? } \\
\text { - Were the findings adequately } \\
\text { summarized, with good use of } \\
\text { tables and figures? } \\
\text { Were findings reported in a } \\
\text { manner that facilitates a meta- } \\
\text { analysis, and with sufficient } \\
\text { information needed for EBP? }\end{array}$ & $\begin{array}{l}\text { Findings were } \\
\text { summarized in three } \\
\text { tables. } \\
\text { The results showed } \\
\text { significant statistical } \\
\text { difference in } \\
\text { postoperative anxiety } \\
\text { between the two } \\
\text { groups. The average } \\
\text { anxiety of research } \\
\text { group was } \\
67.13 \pm 11.320 \text { which } \\
\text { was lower than that } \\
\text { of control group } \\
\text { which was } \\
76.33 \pm 14.227\end{array}$ \\
\hline
\end{tabular}




\begin{tabular}{|c|c|c|}
\hline Aspect of the Report & Critiquing Questions & $\begin{array}{c}\text { Detailed Critiquing } \\
\text { Guidelines }\end{array}$ \\
\hline Cont'd & & $\begin{array}{l}(\mathrm{P}<0.0 .5) \text {. There was } \\
\text { not a significant } \\
\text { statistical difference } \\
\text { in preoperative } \\
\text { anxiety of both } \\
\text { children and parents } \\
\text { between the two } \\
\text { groups. }\end{array}$ \\
\hline $\begin{array}{l}\text { Discussion } \\
\text { Interpretation of the } \\
\text { findings }\end{array}$ & $\begin{array}{l}\text { - Were all major findings } \\
\text { interpreted and discussed within } \\
\text { the context of prior research } \\
\text { and/or the study's conceptual } \\
\text { framework? } \\
\text { - Were casual inferences, if any, } \\
\text { justified? } \\
\text { - Was the issue of clinical } \\
\text { significance discussed? } \\
\text { Were interpretations well-founded } \\
\text { and consistent with the study's } \\
\text { limitations? } \\
\text { Did the report address the issue of } \\
\text { the generalizability of the } \\
\text { findings? }\end{array}$ & $\begin{array}{l}\text { The findings were } \\
\text { discussed in the } \\
\text { content of the } \\
\text { research question. } \\
\text { Findings were } \\
\text { discussed within } \\
\text { context of previous } \\
\text { research. } \\
\text { Clinical significance } \\
\text { and generalizability } \\
\text { were discussed }\end{array}$ \\
\hline $\begin{array}{l}\text { Implications/ } \\
\text { recommendations }\end{array}$ & $\begin{array}{l}\text { Did the researchers discuss the } \\
\text { implications of the study for } \\
\text { clinical practice or further } \\
\text { research-and were those } \\
\text { implications reasonable and } \\
\text { complete? }\end{array}$ & $\begin{array}{l}\text { The researchers } \\
\text { discussed the } \\
\text { implications of the } \\
\text { study although they } \\
\text { did not discuss the } \\
\text { need for further } \\
\text { studies. } \\
\text { The implications } \\
\text { made were } \\
\text { reasonable and } \\
\text { complete. }\end{array}$ \\
\hline $\begin{array}{l}\text { General Issues } \\
\text { Presentation }\end{array}$ & $\begin{array}{l}\text { Was the report well-written, } \\
\text { organized, and sufficiently detailed } \\
\text { for critical analysis? } \\
\text { In intervention studies, was a } \\
\text { CONSORT flowchart provided to } \\
\text { show the flow of participants in } \\
\text { the study? }\end{array}$ & $\begin{array}{l}\text { The report was well- } \\
\text { written, easy to } \\
\text { follow, and organized. } \\
\text { The report was } \\
\text { written in a manner } \\
\text { that was accessible } \\
\text { for practicing nurses. } \\
\text { CONSORT flow chart } \\
\text { was not used. }\end{array}$ \\
\hline
\end{tabular}




\begin{tabular}{|l|l|l|}
\hline Aspect of the Report & \multicolumn{1}{|c|}{ Critiquing Questions } & \multicolumn{1}{c|}{$\begin{array}{c}\text { Detailed } \\
\text { Critiquing } \\
\text { Guidelines }\end{array}$} \\
\hline $\begin{array}{l}\text { General Issues } \\
\text { Presentation } \\
\text { (continued) }\end{array}$ & $\begin{array}{l}\text { Was the report written in a } \\
\text { manner that makes the findings } \\
\text { accessible to practicing nurses? }\end{array}$ & \\
\hline Researcher credibility & $\begin{array}{l}\text { Do the researchers' clinical, } \\
\text { substantive, or methodologic } \\
\text { qualifications and experience } \\
\text { enhance confidence in the findings } \\
\text { and their interpretation? }\end{array}$ & $\begin{array}{l}\text { There was } \\
\text { information about } \\
\text { the authors on the } \\
\text { first page although, } \\
\text { it did not describe } \\
\text { their qualifications } \\
\text { or experience. }\end{array}$ \\
\hline Summary assessment & $\begin{array}{l}\text { Despite any limitations, do the } \\
\text { study findings appear to be valid- } \\
\text { do you have confidence in the } \\
\text { truth value of the results? } \\
\text { Does the study contribute any } \\
\text { meaningful evidence that can be } \\
\text { used in nursing practice or that is } \\
\text { useful to the nursing discipline? }\end{array}$ & $\begin{array}{l}\text { The study findings } \\
\text { do appear to be } \\
\text { valid and hold true } \\
\text { value. }\end{array}$ \\
\hline & \begin{tabular}{l} 
\\
\hline
\end{tabular} & \\
\hline
\end{tabular}

*Reprinted with permission from the editor of D. Polit and C. Beck (2017). Nursing Research. Generating and assessing evidence for nursing practice $\left(10^{\text {th }} \mathrm{ed}\right.$.). Wolters Kluwer. 


\section{Appendix B-1}

Chundamala, J., Wright, J. G., \& Kemp, S. M. (2008). An evidence-based review of parental presence during anesthesia induction and parent/child anxiety. Canadian Journal of Anesthesia/Journal Canadien Danesthésie,56(1), 57-70.

\begin{tabular}{|c|c|c|c|}
\hline Purpose & Findings & $\begin{array}{l}\text { Limitations to the } \\
\text { study }\end{array}$ & $\begin{array}{l}\text { Suggestions or } \\
\text { interventions to } \\
\text { improve }\end{array}$ \\
\hline $\begin{array}{l}\text { To examine the } \\
\text { effect of parental } \\
\text { presence during } \\
\text { anesthesia } \\
\text { induction on } \\
\text { parents' and } \\
\text { childrens' anxiety. }\end{array}$ & $\begin{array}{l}\text { Fourteen studies } \\
\text { were included. Of } \\
\text { the } 10 \text { studies that } \\
\text { evaluated parents' } \\
\text { anxiety, } 6 \text { studies } \\
\text { did not show } \\
\text { parental presence } \\
\text { to be more } \\
\text { effective than no } \\
\text { parental presence, } \\
\text { midazolam, or } \\
\text { midazolam with } \\
\text { parental presence. } \\
\text { Of } 11 \text { studies that } \\
\text { examined } \\
\text { childrens' anxiety, } \\
5 \text { of the studies did } \\
\text { not find parental } \\
\text { presence to be } \\
\text { more effective } \\
\text { than no parental } \\
\text { presence, } \\
\text { midazolam, } \\
\text { midazolam with } \\
\text { parental presence, } \\
\text { or parental } \\
\text { presence with the } \\
\text { use of a video } \\
\text { game. }\end{array}$ & $\begin{array}{l}\text { There were } \\
\text { variations in the } \\
\text { ways that studies } \\
\text { measured anxiety. } \\
\text { For example, } \\
\text { parent reports, staff } \\
\text { observations, pulse } \\
\text { rates, standardized } \\
\text { questionnaires, and } \\
\text { study specific } \\
\text { questionnaires were } \\
\text { all used to measure } \\
\text { anxiety in the } \\
\text { studies. } \\
\text { There were } \\
\text { variations in the } \\
\text { times that the } \\
\text { studies measured } \\
\text { anxiety. For } \\
\text { example, anxiety } \\
\text { was measured at } \\
\text { various time points, } \\
\text { including } \\
\text { preoperatively, } \\
\text { during induction, } \\
\text { and following } \\
\text { separation. } \\
\text { The quality of the } \\
\text { studies reviewed } \\
\text { was a limitation: } \\
\text { Many were RCTs, } \\
\text { but none of them } \\
\text { were double blind. }\end{array}$ & $\begin{array}{l}\text { Authors suggested that } \\
\text { there are a number of } \\
\text { areas that would be of } \\
\text { interest for future } \\
\text { research into parental } \\
\text { presence. They } \\
\text { suggested that further } \\
\text { exploration into the } \\
\text { relationship/interaction } \\
\text { between the state of } \\
\text { childrens' and parents' } \\
\text { anxiety and impact on } \\
\text { the effectiveness of } \\
\text { parental presence was } \\
\text { indicated. } \\
\text { Randomized trial are } \\
\text { needed with sufficient } \\
\text { power to evaluate each } \\
\text { subgroup and that } \\
\text { subjectively and } \\
\text { objectively measure } \\
\text { childrens' and parents' } \\
\text { anxiety. }\end{array}$ \\
\hline
\end{tabular}




\section{Appendix B-2}

Vagnoli, L., Caprilli, S., and Messeri, A. (2010). Parental presence, clowns or sedative premedication to treat preoperative anxiety in children: what could be the most promising option. Pediatric Anesthesia, 20, 937-943.

\begin{tabular}{|c|c|c|c|}
\hline Purpose & Findings & $\begin{array}{l}\text { Limitations to the } \\
\text { study }\end{array}$ & $\begin{array}{l}\text { Suggestions or } \\
\text { interventions to } \\
\text { improve }\end{array}$ \\
\hline $\begin{array}{l}\text { To investigate } \\
\text { which intervention, } \\
\text { parental presence, } \\
\text { clowns or sedative } \\
\text { premedications, was } \\
\text { best in reducing } \\
\text { preoperative } \\
\text { anxiety. }\end{array}$ & $\begin{array}{l}\text { The results showed } \\
\text { no significant } \\
\text { differences between } \\
\text { the premedication } \\
\text { group and the } \\
\text { control group. The } \\
\text { clown group was } \\
\text { significantly less } \\
\text { anxious during the } \\
\text { induction of } \\
\text { anesthesia } \\
\text { compared with the } \\
\text { control group and } \\
\text { premedication } \\
\text { group. There was a } \\
\text { significant } \\
\text { correlation between } \\
\text { state anxiety } \\
\text { (STAI-Y-1) and } \\
\text { trait anxiety (STAI } \\
\text { Y-2) (r=0.23: P < } \\
\text { 0.05). } \\
\text { PPIA and clown } \\
\text { interventions were } \\
\text { more effective in } \\
\text { reducing children's } \\
\text { anxiety than PPIA } \\
\text { or PPIA and oral } \\
\text { midazolam. }\end{array}$ & $\begin{array}{l}\text { Study limitations } \\
\text { included lack of } \\
\text { data on time of } \\
\text { induction, small } \\
\text { sample size } \\
(\mathrm{N}=30) \text {, and any } \\
\text { differences in } \\
\text { adverse behavioral } \\
\text { responses in each } \\
\text { group post- } \\
\text { discharge. }\end{array}$ & $\begin{array}{l}\text { The authors } \\
\text { suggested future } \\
\text { studies to compare } \\
\text { clown intervention } \\
\text { alone with PPIA } \\
\text { and with } \\
\text { midazolam to } \\
\text { determine which } \\
\text { lessens the } \\
\text { childrens' anxiety } \\
\text { the most. }\end{array}$ \\
\hline
\end{tabular}




\section{Appendix B-3}

Rasti, R., Jahanpour, F., \& Motamed, N. (2014). The effect of parental presence on anxiety during anesthesia induction in children 2 to 11 years of age undergoing surgery. Journal of Jahrom University of Medical Sciences, 12(1), 9-17. doi:10.29252/jmj.12.1.

\begin{tabular}{|c|c|c|c|}
\hline Purpose & Findings & $\begin{array}{l}\text { Limitations to the } \\
\text { study }\end{array}$ & $\begin{array}{l}\text { Suggestions or } \\
\text { interventions to } \\
\text { improve }\end{array}$ \\
\hline $\begin{array}{l}\text { To examine the } \\
\text { effect of parental } \\
\text { presence on anxiety } \\
\text { during anesthesia } \\
\text { induction in } \\
\text { children } 2 \text { to } 11 \\
\text { years of age } \\
\text { undergoing } \\
\text { surgery. }\end{array}$ & $\begin{array}{l}\text { The results showed } \\
\text { no significant } \\
\text { difference between } \\
\text { the mean total score } \\
\text { of the childrens' } \\
\text { anxiety in the } \\
\text { control group } \\
\text { ( } 70.39 \pm 20.93 \text { ) and } \\
\text { the experimental } \\
\text { group } \\
\text { (67.83 } \pm 16.78) \\
\text { before surgery } \\
\text { (p }>0.05) \text {. Results } \\
\text { showed no } \\
\text { statistically } \\
\text { significant } \\
\text { difference between } \\
\text { changes in the } \\
\text { childrens' anxiety } \\
\text { total score in the } \\
\text { control group } \\
(-3 \pm 16.45 \text { ) and the } \\
\text { experimental group } \\
(-8.39 \pm 22.95 \text { ) } \\
\text { before and after } \\
\text { surgery ( }>0.05 \text { ). }\end{array}$ & $\begin{array}{l}\text { The sample size } \\
\text { was small }(\mathrm{N}=60) \text {. } \\
\text { Participants were } \\
\text { from teaching } \\
\text { medical centers in } \\
\text { Boushehr. The } \\
\text { study population } \\
\text { included aged 2-11 } \\
\text { years old and were } \\
\text { mostly male } \\
\text { participants } \\
(73.3 \%) \text {. }\end{array}$ & $\begin{array}{l}\text { Authors suggested } \\
\text { that more effective } \\
\text { interventions should } \\
\text { be conducted in } \\
\text { order to prepare } \\
\text { children undergoing } \\
\text { surgical procedures } \\
\text { to reduce their } \\
\text { anxiety. }\end{array}$ \\
\hline
\end{tabular}




\section{Appendix B-4}

Jahanpour, F., Rasti-Emad-Abadi, R., Naboureh, A., Nasiri, M., \& Motamed, N. (2017).

The effects of preanesthetic parental presence on preoperative anxiety of children and their parents: A randomized clinical trial study in Iran. Iranian Journal of Nursing and Midwifery Research,22(1), 72.

\begin{tabular}{|c|c|c|c|}
\hline Purpose & Findings & $\begin{array}{l}\text { Limitations to the } \\
\text { study }\end{array}$ & $\begin{array}{l}\text { Suggestions or } \\
\text { interventions to } \\
\text { improve }\end{array}$ \\
\hline $\begin{array}{l}\text { To examine the } \\
\text { effects of PPIA on } \\
\text { preoperative } \\
\text { anxiety of children } \\
\text { as well as their } \\
\text { parents. }\end{array}$ & $\begin{array}{l}\text { The results showed } \\
\text { no significant } \\
\text { difference between } \\
\text { childrens' anxiety } \\
\text { in the control group } \\
\text { (70.39) and } \\
\text { intervention group } \\
\text { (70.83) during the } \\
\text { preanesthetic } \\
\text { period. } \\
\text { There was no } \\
\text { significant } \\
\text { difference between } \\
\text { the control group } \\
\text { (85.86) and the } \\
\text { intervention group } \\
\text { (79.23) regarding } \\
\text { parents' anxiety. }\end{array}$ & $\begin{array}{l}\text { The study had } \\
\text { limitations that may } \\
\text { have impacted the } \\
\text { results such as the } \\
\text { amount of time the } \\
\text { health care } \\
\text { providers spent } \\
\text { preparing each } \\
\text { family. Also, all } \\
\text { parents in the study } \\
\text { were given the } \\
\text { option to be present } \\
\text { during the } \\
\text { induction of } \\
\text { anesthesia } \\
\text { regardless of how } \\
\text { anxious their child } \\
\text { was. }\end{array}$ & $\begin{array}{l}\text { Authors suggested } \\
\text { that future studies } \\
\text { in this area are } \\
\text { needed to clarify } \\
\text { the effects of PPIA } \\
\text { on preoperative } \\
\text { anxiety. }\end{array}$ \\
\hline
\end{tabular}




\section{Appendix B-5}

Sadeghi, A., Khaleghnejad Tabari, A., Mahdavi, A., Salarian, S., \& Sajjad Razavi, S. (2017). Impact of parental presence during induction of anesthesia on anxiety level among pediatric patients and their parents: A randomized clinical trial. Neuropsychiatric Disease

and Treatment, 12, 3237-3241.

\begin{tabular}{|c|c|c|c|}
\hline Purpose & Findings & $\begin{array}{l}\text { Limitations to } \\
\text { the study }\end{array}$ & $\begin{array}{l}\text { Suggestions or } \\
\text { interventions to } \\
\text { improve }\end{array}$ \\
\hline $\begin{array}{l}\text { To assess the } \\
\text { impact of parental } \\
\text { presence during } \\
\text { induction of } \\
\text { anesthesia and } \\
\text { preoperative } \\
\text { anxiety of } \\
\text { pediatric patients. }\end{array}$ & $\begin{array}{l}\text { The results showed } \\
\text { no significant } \\
\text { difference in the } \\
\text { mYPAS of } \\
\text { participants in the } \\
\text { PPIA and control } \\
\text { groups at T0 } \\
(33.4 \pm 13.6 \text { vs } \\
37.9 \pm 17.4 ; \mathrm{P}=0.162) \\
\text { and T1 (41.01 } \pm 18.5 \\
\text { vs } 44.2 \pm 17.4 ; \\
\mathrm{P}=0.42) \text {. However, } \\
\text { the mean mYPAS } \\
\text { score was different at } \\
\text { the time of induction } \\
\text { of anesthesia T2 } \\
(35.5 \pm 16.6 \text { vs } \\
59.8 \pm 22.4 \text {; }<0.001) \text {. } \\
\text { The STAI scores of } \\
\text { the parents showed } \\
\text { no difference in the } \\
\text { T0, T1, and T2. The } \\
\text { mean parental } \\
\text { satisfaction score was } \\
\text { higher in the PPIA } \\
\text { group than the } \\
\text { control group. } \\
(7.6 \pm 7.0 \text { vs } 5.8 \pm 6.1 ; \\
\text { P }<0.01) \text {. }\end{array}$ & $\begin{array}{l}\text { Limitations } \\
\text { included the } \\
\text { inability to } \\
\text { perform all } \\
\text { morning surgeries } \\
\text { which influenced } \\
\text { the waiting time } \\
\text { and NPO status } \\
\text { which may have } \\
\text { impacted stress } \\
\text { and anxiety of the } \\
\text { participants. }\end{array}$ & $\begin{array}{l}\text { The authors } \\
\text { suggested that } \\
\text { studies on pediatric } \\
\text { patients should be } \\
\text { conducted at the } \\
\text { earliest time on the } \\
\text { operating room } \\
\text { schedule. }\end{array}$ \\
\hline
\end{tabular}




\section{Appendix B-6}

Sun, Y., Qi, S., Dong, X., An, J., \& Yuan, H. (2017). The effect of parental presence to perioperative anxiety of Chinese children and their parents. Biomedical Research,28(17), 7519-7522.

\begin{tabular}{|c|c|c|c|}
\hline Purpose & Findings & $\begin{array}{l}\text { Limitations to the } \\
\text { study }\end{array}$ & $\begin{array}{l}\text { Suggestions or } \\
\text { interventions to } \\
\text { improve }\end{array}$ \\
\hline $\begin{array}{l}\text { To examine the } \\
\text { effect of parental } \\
\text { presence to } \\
\text { perioperative } \\
\text { anxiety of Chinese } \\
\text { children and their } \\
\text { parents. }\end{array}$ & $\begin{array}{l}\text { The results showed } \\
\text { preoperative and } \\
\text { postoperative } \\
\text { anxiety in children } \\
\text { in the research } \\
\text { group was } \\
\text { significantly lower } \\
\text { than the control } \\
\text { group. The average } \\
\text { anxiety of research } \\
\text { group was } \\
67.13 \pm 11.320 \text { which } \\
\text { was lower than that } \\
\text { of control group } \\
\text { which was } \\
76.33 \pm 14.227 \text { (P < } \\
\text { 0.0.5). The parents } \\
\text { in the control group } \\
\text { and research group } \\
\text { showed no } \\
\text { significant } \\
\text { difference in } \\
\text { preoperative } \\
\text { anxiety. The } \\
\text { postoperative } \\
\text { anxiety of parents } \\
\text { in the research } \\
\text { group was } \\
\text { significantly lower } \\
\text { than the control } \\
\text { group. }\end{array}$ & $\begin{array}{l}\text { Limitations in the } \\
\text { methods included } \\
\text { the parents' ability } \\
\text { to relax their child } \\
\text { using conventional } \\
\text { methods such as } \\
\text { attention transfer } \\
\text { and telling a } \\
\text { favorite story. }\end{array}$ & $\begin{array}{l}\text { The authors } \\
\text { suggested } \\
\text { presenting parents } \\
\text { with conventional } \\
\text { methods such as } \\
\text { attention transfer, } \\
\text { including telling a } \\
\text { favorite story to } \\
\text { relax with their } \\
\text { children during the } \\
\text { perioperative period } \\
\text { to reduce } \\
\text { postoperative } \\
\text { anxiety of children } \\
\text { and their parents. }\end{array}$ \\
\hline
\end{tabular}




\section{Appendix C}

\section{Cross Study Analysis}

\begin{tabular}{|c|c|}
\hline AUTHOR & Chundamala, J., Wright, J. G., \& Kemp, S. M. (2008) \\
\hline Key Findings & $\begin{array}{l}\text {-Parental presence did not appear to alleviate childrens' or } \\
\text { parents' anxiety. } \\
\text {-When the childrens' or parents' anxiety was reduced, it was } \\
\text { most often due to the administration of premedication such as } \\
\text { midazolam. } \\
\text {-Anxiety should be reduced with anxiety-reducing solutions such } \\
\text { as distraction (ex: video games) }\end{array}$ \\
\hline Recommendations & $\begin{array}{l}\text { The authors suggested further exploration into the } \\
\text { relationship/interaction between the state of childrens' } \\
\text { and parents' anxiety and impact on the effectiveness of } \\
\text { parental presence. } \\
\text { - Randomized trials are needed with significant power to } \\
\text { evaluate each subgroup and that subjectively and } \\
\text { objectively measure childrens' and parents' anxiety. }\end{array}$ \\
\hline Limitations & $\begin{array}{l}\text {-Variations existed in the times that the study measured anxiety } \\
\text { and the measurements used in the study such as staff } \\
\text { observations, pulse rates, standardized questionnaires, and parent } \\
\text { reports. }\end{array}$ \\
\hline AUTHOR & Vagnoli, L., Caprilli, S., \& Messeri, A. (2010) \\
\hline Key Findings & $\begin{array}{l}\text {-PPIA and clown intervention were more effective than PPIA } \\
\text { alone or PPIA and oral midazolam in reducing preoperative } \\
\text { anxiety in children. } \\
\text {-There has been an increase in the presence of clowns in } \\
\text { pediatric hospitals. } \\
\text {-Children over seven years old have higher anxiety levels than } \\
\text { younger children in general. } \\
\text {-Parents' anxiety is a predictor of the childs' anxiety during the } \\
\text { preoperative period. }\end{array}$ \\
\hline Recommendations & $\begin{array}{l}\text { Professional clown doctors should be encouraged to } \\
\text { manage childrens' anxiety during the preoperative phase } \\
\text { of anesthesia. }\end{array}$ \\
\hline Limitations & $\begin{array}{l}\text {-There was lack of data on time of induction. } \\
\text {-Each group had differences in adverse behavioral responses } \\
\text { during post-discharge. }\end{array}$ \\
\hline AUTHOR & Rasti, R., Jahanpour, F., \& Motamed, N. (2014) \\
\hline
\end{tabular}




\begin{tabular}{|c|c|}
\hline Key Findings & $\begin{array}{l}\text {-There was no significant difference between the mean total } \\
\text { score of childrens' anxiety in the experimental group and the } \\
\text { control group before and after surgery. } \\
\text {-Results showed that parental presence had no significant effect } \\
\text { on childrens' anxiety while undergoing anesthesia. }\end{array}$ \\
\hline Recommendations & $\begin{array}{l}\text { - Other effective interventions should be investigated to } \\
\text { reduce the effects of childrens' anxiety while undergoing } \\
\text { surgery. } \\
\text { - Providing families with appropriate preparation and } \\
\text { informative programs. } \\
\text { - Administering sedatives prior to surgery. }\end{array}$ \\
\hline Limitations & $\begin{array}{l}\text { Participants were from teaching medical centers in Boushehr. } \\
\text { The study population included aged 2-11 years old and were } \\
\text { mostly male participants }\end{array}$ \\
\hline AUTHOR & $\begin{array}{l}\text { Jahanpour, F., Rasti-Emad-Abadi, R., Naboureh, A., Nasiri, M., } \\
\text { \& Motamed, N. (2017) }\end{array}$ \\
\hline Key Findings & $\begin{array}{l}\text {-There was no significant difference between the intervention } \\
\text { and control group regarding parents' anxiety. } \\
\text {-No significant difference was found between childrens' anxiety } \\
\text { in the intervention and control groups during the preanesthetic } \\
\text { period. } \\
\text {-PPIA had no effects on reducing the childrens' or parents' } \\
\text { anxiety. }\end{array}$ \\
\hline Recommendations & $\begin{array}{l}\text { Future studies are needed to clarify the effects of parental } \\
\text { presence on preoperative anxiety of children and their } \\
\text { parents. }\end{array}$ \\
\hline Limitations & $\begin{array}{l}\text {-Instructions given to the parents during preparation and before } \\
\text { being led into the OR may have impacted the results. Second, all } \\
\text { parents were given the option to be present during the induction } \\
\text { of anesthesia regardless of their anxiety or their childs' anxiety. } \\
\text { Lastly, parents were told they were allowed to hold their childs' } \\
\text { hand during induction of anesthesia which may have directed the } \\
\text { behaviors of the parents and may have impacted the childrens' } \\
\text { anxiety. }\end{array}$ \\
\hline AUTHOR & $\begin{array}{l}\text { Sadeghi, A., Khaleghnejad Tabari, A., Mahdavi, A., Salarian, S., } \\
\text { \& Sajjad Razavi, S. (2017) }\end{array}$ \\
\hline Key Findings & $\begin{array}{l}\text {-Parental presence did not impact parental state anxiety. } \\
\text {-PPIA may decrease preoperative state anxiety. } \\
\text {-PPIA improved quality of anesthesia based on high parental } \\
\text { satisfaction and ICC scores. }\end{array}$ \\
\hline
\end{tabular}




\begin{tabular}{|c|c|}
\hline & $\begin{array}{l}\text {-PPIA has an additive effect on midazolam. PPIA in addition to } \\
\text { oral midazolam can result in better cooperation, decrease in } \\
\text { anxiety, and provide parents with more satisfaction. }\end{array}$ \\
\hline Recommendation & $\begin{array}{l}\text { - Superiority of parental presence to premedications such } \\
\text { as midazolam remains controversial and needs further } \\
\text { study. } \\
\text {-Inability to perform all surgeries in the morning caused an } \\
\text { increase in waiting time and NPO status which could have } \\
\text { impacted anxiety and stress of the participants }\end{array}$ \\
\hline AUTHOR & Sun, Y., Qi, S., Dong, X., An, J., \& Yuan, H. (2017) \\
\hline Key Findings & $\begin{array}{l}\text {-Parental presence allowed parents to help to relax their child and } \\
\text { can be beneficial to pediatric patients in the operating room. } \\
\text {-Parental presence can reduce anxiety of parents. } \\
\text {-Intra-operative anxiety is mainly due to fear of separation and } \\
\text { strange environment. } \\
\text {-Communication between parents and their child and can be } \\
\text { more effective than doctors' or nurses' communication with the } \\
\text { child. }\end{array}$ \\
\hline Recommendations & $\begin{array}{l}\text { The more parents know and understand about the } \\
\text { operation, the more satisfied parents are likely to be and } \\
\text { children may exhibit less anxiety. } \\
\text { - Future studies are needed to examine the effect of } \\
\text { parental presence on perioperative anxiety. }\end{array}$ \\
\hline Limitations & $\begin{array}{l}\text {-Parents' ability to relax their child using conventional methods } \\
\text { such as attention transfer and telling a favorite story while } \\
\text { previous studies asked parents to do no interventions }\end{array}$ \\
\hline
\end{tabular}

